MARIA EDUARDA FLECK DA ROSA

\title{
O PODER NORMATIVO DA COMISSÃO DE VALORES MOBILIÁRIOS
}

\author{
DiSSERTAÇÃo DE MESTRAdO
}

Orientador: Professor Dr. Francisco Satiro de Souza Junior

FACULDADE DE DIREITO DA USP

SÃO PAULO

2012 


\section{O PODER NORMATIVO DA COMISSÃO DE VALORES MOBILIÁRIOS}

Dissertação de Mestrado apresentada à Banca Examinadora da Faculdade de Direito da Universidade de São Paulo, como exigência parcial para a obtenção do título de Mestre em Direito, sob orientação do Prof. Dr. Francisco Satiro de Souza Junior

FACULDADE DE DIREITO DA USP

SÃO PAULO 
MARIA EDUARDA FLECK DA ROSA

\section{O PODER NORMATIVO DA COMISSÃO DE VALORES MOBILIÁRIOS}

MEMBROS DA BANCA EXAMINADORA

PROF. DR. FRANCISCO SATIRO DE SOUZA JUNIOR 


\section{RESUMO}

A presente dissertação tem por objeto a análise do poder normativo da Comissão de Valores Mobiliários, que pautar-se-á pelo estudo da Teoria Geral do Direito. Para isso, contribuições de diversos campos do conhecimento serão utilizadas, tais como a teoria analítica da norma, a lógica deôntica, a teoria da linguagem, bem como aportes advindos de outras áreas do conhecimento, como da ciência econômica. Ao longo do trabalho, procuraremos responder a três perguntas chaves que, para o que aqui nos propusemos, serão de grande valia na fixação dos limites a serem observados pela Comissão de Valores Mobiliários no exercício de seu poder normativo. A primeira pergunta que responderemos refere-se à finalidade da regulação no mercado de capitais. Para isso, perquiriremos os motivos que ensejaram a concepção da Comissão, bem como o que se buscava por meio de sua criação. Com isso, demonstraremos que a Comissão de Valores Mobiliários nasce em um ambiente de crise, no qual se buscava restaurar a credibilidade e a segurança do mercado de capitais, por meio da criação de um órgão disciplinador especializado. A segunda pergunta que nos propusemos a responder, nos remete à natureza jurídica da Comissão de Valores Mobiliários. Abordaremos, para isso, o tratamento dado pela doutrina aos órgãos reguladores para, ao final, justificar que sua natureza de autarquia sob regime especial a ela conferiu status de agência reguladora. Por fim, a última questão busca tratar dos limites legais e constitucionais a serem observados pela Comissão de Valores Mobiliários no exercício de seu poder normativo. Para isso, verificaremos as competências, atribuições e deveres que foram por lei conferidos à Comissão, de forma a concluir que se está diante de um órgão de competência híbrida. Explica-se. Nas situações expressamente previstas nas Leis n. ${ }^{\circ}$ 6.385/1976 e n. ${ }^{\circ}$ 6.404/1976, caberá à Comissão fazer uso de seu poder regulamentar, a fim de, por meio da operacionalização dos comandos legais, dar o fiel cumprimento às regras ali contidas, nos termos do espírito de sua criação, veiculado nos incisos do artigo $4^{\circ}$, da Lei n..$^{\circ}$ 6.385/1976, bem como no quanto disposto na Constituição Federal. De outra banda, nos casos que não aqueles expressamente previstos nas Leis n. ${ }^{\circ}$ 6.385/1976 e n. ${ }^{\circ}$ 6.404/1976, mas ainda assim intrínseca e legalmente ligados ao mercado de capitais, poderá a Comissão de Valores Mobiliário, no uso de sua competência suplementar reguladora, inovar no sistema, de forma a integrar lacunas na ausência de norma específica legal, a fim de conferir ao mercado eficiência, e a seus agentes segurança jurídica. $\mathrm{O}$ exercício desta competência suplementar, a exemplo da competência regulamentar, será também pautado pelos mesmos limites do artigo $4^{\circ}$, da Lei n. ${ }^{\circ}$ 6.385/1976 e da Constituição Federal.

Palavras-chave: Comissão de Valores Mobiliários; poder normativo; limites. 


\begin{abstract}
The present dissertation aims to analyze the normative power of the Brazilian Securities and Exchange Commission ("Comissão de Valores Mobiliários") from a Jurisprudential point of view, which means an application of several epistemic tools such as the analytical theory of the norm, deontic logic, philosophy of language and economics in order to accomplish this academic enterprise. There are three key issues to define the threshold of CVM's normative power. The first one is what are capital market regulation main goals and the reasons that lead to the creation of CVM and its mission. The second one is the actual legal status of CVM as a special "autarquia" and regulatory agency. Finally the statutory and constitutional limits to the normative powers of CVM are analyzed to realize it has a hybrid normative power: partly creating norms to give effectiveness to some sections of Laws n. ${ }^{\circ} 6.385 / 1976$ and $n .^{\circ} 6.404 / 1976$, according to specific statutory and constitutional dispositions; and partly acting as a typical regulatory agency to create independent norms to ensure market efficiency and legal certainty.
\end{abstract}

Key words: Brazilian Securities and Exchange Commission ("Comissão de Valores Mobiliários"); normative power; limits. 


\section{SUMÁRIO}

INTRODUÇÃ̃O

1. DIREITO, REGULAÇÃO E MERCADO DE CAPITAIS .............................................. 12

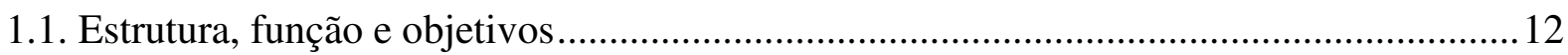

1.2. Regulação e mercado de capitais .............................................................................. 17

1.2.1. Regulação e Economia: breves comentários......................................................... 19

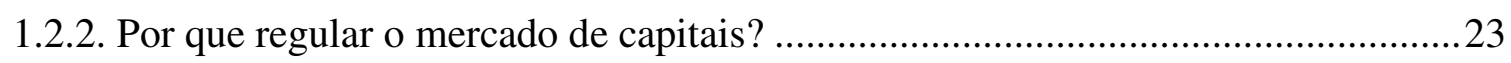

1.2.3. O surgimento da regulação no mercado de capitais: da crise ao mercado de

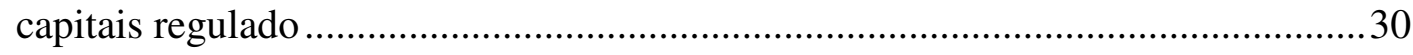

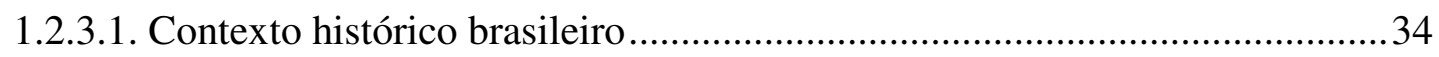

\section{2. ÓRGÃo RESPONSÁVEL PELO MERCADO DE CAPITAIS BRASILEIRO:} QUAL A NATUREZA JURÍDICA DA COMISSÃO DE VALORES MOBILIÁRIOS?

2.1. Mandamentos constitucionais e a Administração Pública ............................................... 38

2.1.1. A separação de poderes....................................................................................... 38

2.1.1.1. A separação de poderes e o Estado Democrático de Direito .........................43

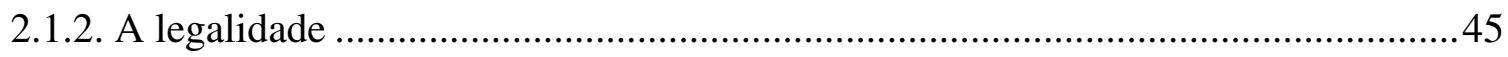

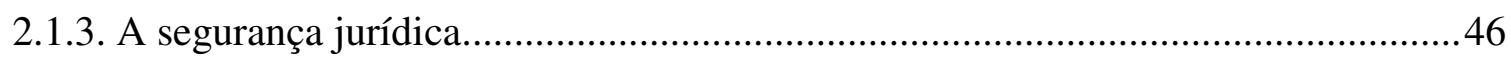

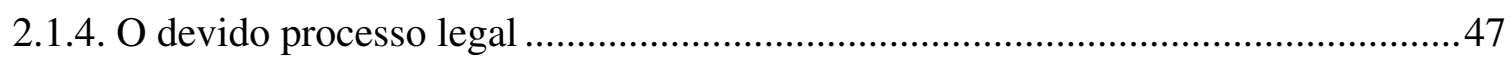

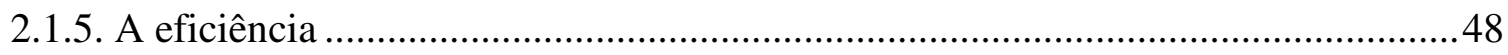

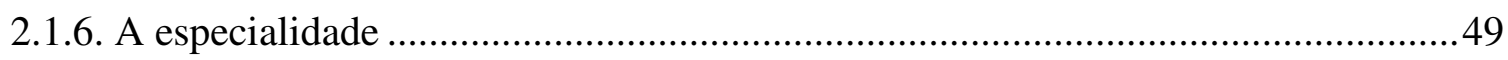

2.2. Autarquias especiais: as agências "reguladoras" .........................................................50

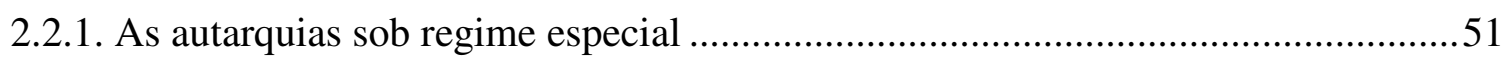

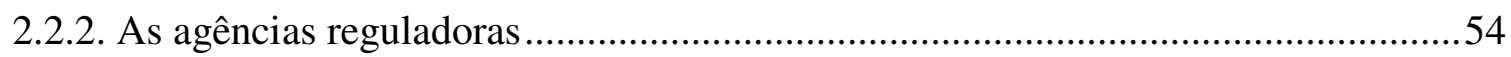

2.2.3. Agências reguladoras ou regulamentadoras? ......................................................61

2.2.4. A Comissão de Valores Mobiliários como autarquia responsável pelo

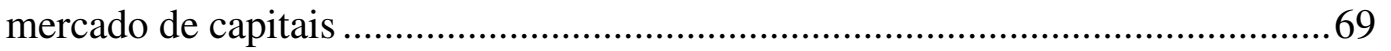

2.2.4.1. A Comissão de Valores Mobiliários e o Conselho de Recursos do Sistema Financeiro Nacional: o problema da ausência de caráter final das decisões proferidas pela Comissão de Valores Mobiliários ....................76

3. O PODER NORMATIVO DA COMISSÃO DE VALORES MOBILIÁRIOS ................81

3.1. Poder e competência: a criação de normas jurídicas........................................................ 81

3.2. Categorias normativas e a Comissão de Valores Mobiliários........................................... 84

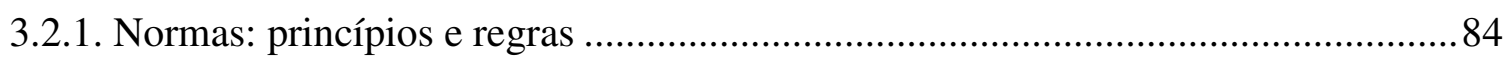

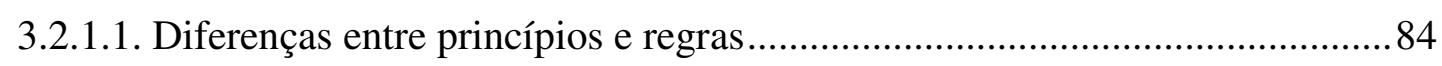


3.2.1.2. Regras abstratas, gerais, concretas e individuais 87

3.2.1.3. Regras de conduta e regras de competência... .90

3.3. Funções da Comissão de Valores Mobiliários: normativa, fiscalizadora, julgadora, de registro, consultiva ou de orientação, sancionadora e de fomento

3.3.1. Funções da Comissão de Valores Mobiliários e o produto do seu exercício: a norma jurídica

3.4. Regulamentação e regulação: a competência híbrida da Comissão de Valores Mobiliários 103

3.4.1. A competência regulamentadora da Comissão de Valores Mobiliários 108

3.4.1.1. O inciso I do artigo $8^{\circ}$, da Lei n. ${ }^{\circ}$ 6.385/1976 e a Instrução CVM n. ${ }^{\circ}$ 480/2009: a divulgação da remuneração dos administradores.

3.4.2. A competência suplementar reguladora da Comissão de Valores Mobiliários .... 114

3.4.2.1. Eficiência, legalidade e segurança jurídica 117

3.4.2.2. A superação da legalidade pelos Princípios da Eficiência e da Segurança Jurídica 122

3.4.2.3. O artigo $4^{\mathrm{o}}$ da Lei . $^{\circ} 6.385 / 1976$ e as lacunas normativas. 124 


\section{INTRODUÇÃO}

Um dos temas que suscitam as mais intensas paixões, devido ao apelo que faz aos valores e às ideologias dos indivíduos, é o da intervenção do Estado na esfera privada.

A intervenção é diretamente relacionada a esta autoridade central que, desde os grandes contratualistas sociais como Thomas Hobbes e Jean Jacques Rousseau, é responsável tanto por proteger quanto por ferir a liberdade do indivíduo. A diferença entre a garantia das liberdades e sua supressão é, assim, apenas de grau, não de natureza, caminhando tal distinção, muitas vezes, sobre o fio da navalha.

Várias foram as experiências práticas no que se refere ao grau de intervencionismo nos dois últimos séculos. Primeiramente com a era do Estado laissez-faire, onde o mesmo limitava-se a cumprir com suas funções essenciais, justamente as de proteger as liberdades individuais por intermédio da segurança interna (polícia), externa (forças armadas) e da solução de conflitos intersubjetivos (judiciário). Em outras palavras, este foi o paradigma do Estado mínimo, vigorante no século dezenove até as primeiras décadas do século seguinte.

Por essa época, o Mundo assistiu a várias reviravoltas. Além do avanço inédito nas ciências naturais, que já caminhavam em passos largos desde o século anterior, culminado em revoluções científicas e tecnológicas tais como o automóvel, o avião, o rádio e o telefone, o planeta também foi sacudido com a Primeira Guerra Mundial (1914-1918), a Revolução Bolchevique na Rússia (1917) e a Grande Depressão (iniciada com a quebra da Bolsa de Nova Iorque, em 1929).

O paradigma do Estado mínimo deu lugar a intervenções de variados graus. Desde o New Deal, nos Estados Unidos da América, até a planificação econômica total na União Soviética, o zeitgeist da época se centrava no governo como o timoneiro da Economia das Nações.

Interessante perceber que os Estados Unidos já contavam com agências reguladoras desde o século dezenove, cuja importância foi aumentada no século seguinte. Com a quebra da bolsa de valores em 1929, surgiu, cinco anos depois, a U.S. Securities and Exchange Commission, órgão regulador do mercado de capitais. A agência brasileira 
análoga, a Comissão de Valores Mobiliários, esperaria ainda mais quatro décadas para nascer.

A partir dos anos setenta do século passado, a tendência passou a ser oposta. Países que haviam experimentado uma intensa participação do Estado na Economia, começaram a ver o governo retirando-se de cena, no fenômeno que a literatura econômica e jurídica estadunidense denominou de deregulation. A Inglaterra, durante o período em que Margaret Thatcher assumiu o principal cargo executivo do país, privatizou empresas públicas e liberalizou sobremaneira o seu sistema econômico.

Mesmo os Estados Unidos da América, país de longa tradição liberal, contava há anos - graças ao New Deal - com considerável intervenção estatal na esfera privada. Com a influência da Chicago School of Economics, e nomes como Milton Friedman e outros proeminentes economistas, a desregulação foi a tônica da época, em setores como transporte, energia e o próprio mercado de capitais. Posteriormente, no final da década seguinte, o Mundo assistiu à derrocada geral dos países do bloco comunista, em grande parte por decorrência do inviável sistema econômico planificado. O Muro de Berlim caiu; a União Soviética se desfez; a China iniciou um processo de abertura de sua economia; e Cuba, a única experiência concreta de socialismo em nosso continente, com o corte dos recursos soviéticos outrora aportados na ilha, viu o seu frágil sistema econômico ruir completamente.

O Brasil demoraria ainda cerca quase duas décadas para implementar o seu próprio programa de privatizações, mais precisamente no governo Collor (Lei $\mathrm{n}^{\circ}$. 8.031/1990), tendo seguimento com o presidente Fernando Henrique Cardoso, a partir de 1995. Mesmo com a ainda forte presença do Estado na Economia, o país colheu diversos benefícios com a desestatização, em termos de melhorias nos serviços públicos e de eficiência geral do setor econômico. Em nosso país, o paradigma da estatização econômica, ou seja, do Estado como agente econômico, passou a ser o da regulação: o Estado como interventor e calibrador da Economia.

Finalmente, com a crise econômica mundial de 2008, o paradigma da deregulation passou a ser questionado, não apenas pelos seus eternos críticos da esquerda, mas inclusive pela direita liberal.

Importante perceber que a despeito de mudanças e ciclos alternantes de paradigmas liberalizantes e estatizantes, o fenômeno da regulação nunca cessou de existir, durante todo 
esse tempo. O laissez-faire existiu apenas na teoria, pois o Estado sempre, em grau menor ou maior, interviu no setor econômico. A grande questão não é, portanto, se deve haver ou não a intervenção, mas sim em que grau deve ela ocorrer.

Conforme dito linhas acima, o Estado é a autoridade central que paradoxalmente tem o poder de proteger as liberdades individuais assim como também o poder de destruílas. Esta tênue diferença se dá pelo grau de sua interferência na esfera privada. O sistema constitucional e os direitos fundamentais que dele fluem servem de anteparo a abusos estatais, mantendo a intervenção no grau desejado pela sociedade, de forma a que o Estado forneça a estrutura institucional necessária para o desenvolvimento socioeconômico, em vez de inibi-lo.

O objetivo desta dissertação é justamente analisar os limites de atuação da Comissão de Valores Mobiliários, como órgão regulador do mercado de capitais brasileiro.

O método de investigação pautar-se-á pela utilização da Teoria Geral do Direito. Cumpre esclarecer que tal disciplina compraz, hodiernamente, contribuições dos mais diversos campos do conhecimento, tais como teoria analítica da norma, lógica deôntica, teoria da linguagem, bem como aportes de outras áreas do conhecimento, como a ciência econômica.

Mas como se pode analisar a delimitação do poder de um órgão estatal regulador? A fim de averiguarmos os limites que devem ser observados pela Comissão de Valores Mobiliários no exercício de seu poder normativo, nos propusemos a responder três perguntas chaves, cuja estrutura apresenta três ângulos de investigação, que, em conjunto, são capazes de fornecer as adequadas respostas.

(a) Qual a finalidade da regulação no mercado de capitais?

(b) Qual a natureza jurídica da Comissão de Valores Mobiliários?

(c) Quais os limites jurídicos impostos à atuação da Comissão de Valores Mobiliários?

De forma a delinear o escopo deste trabalho, nos utilizaremos destas três perguntas retóricas fundamentais que, para o que aqui nos propusemos, serão de grande valia na fixação dos limites a serem observados pela Comissão de Valores Mobiliários na ponência de normas no ordenamento. 
Primeira pergunta: qual a finalidade da regulação no mercado de capitais?

No capítulo 1, apresentaremos as premissas gerais que fundamentam nosso trabalho, bem como trataremos das principais teorias da regulação econômica. A seguir, abordaremos a regulação no âmbito do mercado de capitais, a fim de verificar a que ela se destina. Por fim, traremos o contexto histórico que ensejou a criação de órgãos reguladores do mercado de capitais, isto é, o que se pretendia quando se verificou a necessidade de criação destes entes, notadamente nos Estados Unidos e no Brasil.

Segunda pergunta: qual a natureza jurídica da Comissão de Valores Mobiliários?

Neste capítulo, abordaremos a estrutura constitucional que forma o Estado, entendido este como a conjunção de três poderes fundamentais: o Legislativo, o Judiciário e o Executivo. Nesse diapasão, os principais mandamentos constitucionais que norteiam a atuação da Administração Pública serão analisados.

Em seguida, será abordado o fenômeno das agências reguladoras, desde sua origem nos Estados Unidos até a sua introdução em nosso sistema jurídico. A partir disso, poderemos então investigar a natureza jurídica de nosso próprio órgão regulador do mercado de capitais, a Comissão de Valores Mobiliários.

Terceira pergunta: quais os limites jurídicos impostos à atuação da Comissão de Valores Mobiliários?

Neste terceiro e último capítulo, abordaremos, pela ótica da teoria da norma jurídica, as competências normativas da Comissão de Valores Mobiliários.

Para tanto, apresentaremos as categorias principais da norma jurídica, incluindo a classificação em princípios e regras, bem como as diferentes espécies no que se refere à concreção e destinação das normas, e à sua função de regular comportamentos ou de construir o próprio sistema jurídico.

Em seguida, investigaremos, à luz das ferramentas epistemológicas apresentadas previamente, as clássicas funções da Comissão de Valores Mobiliários em sua atuação como órgão responsável pelo mercado de capitais.

Por fim, apresentaremos a nossa visão de como funciona esta atuação no que se refere à delimitação de sua competência de criar normas jurídicas, introduzindo a proposta de competência híbrida, tanto regulamentadora, quanto reguladora do mercado. 
Cumpre salientar que não é objetivo da presente dissertação escrutinar o mercado de capitais, suas operações, contingências e vicissitudes. Nosso propósito é deslindar os contornos jurídicos e os limites da competência normativa do órgão responsável por coordenar este mercado, e com o auxílio das categorias da Teoria Geral do Direito, esperamos lograr tal intento. 


\section{DIREITO, REGULAÇÃO E MERCADO DE CAPITAIS}

\subsection{Estrutura, função e objetivos}

Considerando que a presente dissertação trata dos limites do poder normativo da Comissão de Valores Mobiliários, deve-se, por rigor científico, estabelecer certas premissas fundamentais, que nortearão o trabalho desde o seu início.

A primeira delas é que regulação pressupõe Direito, i.e., aquela ocorre por intermédio de normas jurídicas, que obrigam, proíbem e permitem condutas intersubjetivas. Não apenas trata-se de uma decorrência lógica, como também denota a própria definição de Direito, conforme Kelsen: sistema de normas que regulam o comportamento humano. ${ }^{1}$

Nessa definição encontra-se a segunda premissa, qual seja, a de que cabe ao sistema normativo coordenar as inúmeras ações individuais que perfazem a ordem social, reconhecendo e traduzindo em linguagem jurídica valores morais e sociais arraigados, bem como delineando e desenvolvendo instituições, que nada mais são que conjuntos de regras, ao mesmo tempo limitadoras e garantidoras da liberdade humana. Nisso encontra-se a função da regulação jurídica.

Por fim, as normas operam visando alcançar objetivos ou fins. A regulação do comportamento social não é um fim em si mesma, mas um meio pelo qual o constituinte e o legislador esperam que certos valores considerados fundamentais sejam cumpridos.

Trataremos brevemente de cada uma dessas premissas, a seguir.

\section{a) Estrutura:}

A inestimável contribuição que o positivismo e a chamada jurisprudência analítica do Direito, cujos principais pioneiros foram ingleses como Jeremy Bentham ${ }^{2}$ e John Austin $^{3}$, e posteriormente o acima referido Hans Kelsen, jurista austríaco, e

\footnotetext{
${ }^{1}$ KELSEN, Hans. Teoria pura do direito. Trad. João Paulo Baptista. São Paulo: Martins Fontes, 2003. p. 5.

${ }^{2}$ Para uma exposição completa do positivismo benthaniano, ver sua obra BENTHAM, Jeremy. The principles of morals and legislation. New York: Prometeu Books, 1988.

${ }^{3}$ Em The Province of Jurisprudence Determined, obra publicada pela primeira vez em 1832, Austin firma a separação entre Direito e Moral e define o primeiro como "comandos emanados pelo soberano e apoiados por ameaças". (AUSTIN, John. The province of jurisprudence determined. New York: Prometeus Books, 2000. p. 13-16).
} 
H. L. A. Hart ${ }^{4}$, também inglês, foi afastar o estudo do fenômeno jurídico de arraigadas visões naturalistas, colocando-o no terreno palpável dos construtos humanos. Guardadas as significativas diferenças entre os pensamentos dos citados pensadores, que sobremodo a sua importância teórica e histórica, de modo algum esgotam o universo de autores identificados com a visão positiva do Direito, alguns pontos em comum merecem ser destacados. Dentre estes, a separação entre a ordem moral e a ordem jurídica.

Ainda que a moral, entendida como o conjunto de princípios e regras sociais criado de forma espontânea, ao longo de gerações, que aglutinam indivíduos em grupos e comunidades, inevitavelmente influencie a criação do Direito, com este não deve ser confundida. Mesmo que jusnaturalistas, de várias correntes, confundam tais domínios, o próprio senso-comum do homem médio é capaz de estabelecer a diferença: "nem sempre o que é legal, é justo", reza o velho adágio.

No que se refere à regulação do mercado propriamente dito, e, mais ainda, do mercado de capitais, tema específico deste trabalho, a discordância entre o que é justo ou injusto no que se refere às normas emitidas pelo legislador ou pela Comissão de Valores Mobiliários é certamente muito maior, portanto de caráter substancialmente mais subjetivo do que a análise puramente jurídica das mesmas regras.

Outro aspecto fundamental é que o Direito consubstancia-se num sistema, de coordenações horizontais e verticais, cujos elementos são comandos emanados de uma fonte tida como legítima, i.e., de caráter oficial. Em outras palavras, comandos advindos de um foco central, comumente denominado de Estado. Em última instância, as regras que (de)limitam a liberdade humana têm por origem a entidade imbuída de autoridade central sobre toda a sociedade.

Mesmo o Direito Privado, que ao menos nos regimes democráticos contém o maior número de normas, veiculadas por contratos de todo o tipo, tem seu alicerce construído pelo legislador, esfera de poder pertencente à tripartição que forma o Estado. Como se isso não bastasse, mesmo que contratos sejam firmados, em sua maior parte, por e entre cidadãos comuns, apenas o Estado - agora por meio do Judiciário - pode empregar o uso da força para obrigar o seu cumprimento pela parte inadimplente.

${ }^{4} \mathrm{O}$ positivista mais influente da língua inglesa, tendo por obra principal The Concept of Law, publicado em 1961. 
Quando se trata de regulação de mercado, ao menos no sentido coercivo da expressão, a mesma só ocorre por intermédio de normas jurídicas. É certo que a expressão autorregulação dos mercados, que se refere à incrível capacidade que as ações impessoais, contínuas e autointeressadas dos indivíduos têm para gerar equilíbrio - a chamada "mão invisível" de Adam Smith - não se confunde com a regulação normativa aqui referida. ${ }^{5}$

Esta, também denominada de "heterorregulação", na lição de Rachel Sztajn", pressupõe intervenção do Estado no mercado, enquanto aquela denota a tendência ao equilíbrio sistêmico que os livres mercados possuem. Como veremos, todavia, em certas situações denominadas "falhas de mercado", às vezes tal intervenção se justifica e é desejável.

Por fim, outro dos denominadores comuns entre os analíticos ou positivistas é considerar que a atuação do Estado, organização que cria e impõe a macroinstituição chamada "Direito", pressupõe o estabelecimento de poderes ou competências ${ }^{7}$ para tanto. Nesse sentido, o Estado, seja por meio do executivo, legislativo ou judiciário, só pode regular condutas porque o próprio sistema assim prevê.

Trata-se de um fenômeno de constante autorregulação e autoprodução da ordem jurídica. Se o Executivo pode regulamentar leis, é porque a Constituição assim determina; se o Legislativo pode criar leis, tal possibilidade está prevista pela Carta Maior, assim como em leis e regimentos; se ao juiz cabe decidir litígios, tal prerrogativa deve-se novamente à Constituição, bem como aos códigos de processo que determinam os procedimentos para tanto.

A visão estruturalista ou positivista da regulação, portanto, a vê como um fenômeno essencialmente jurídico, por meio de uma análise endógena, autocentrada no sistema do Direito positivo. Suas lentes concentram-se nos elementos do sistema jurídico, que se pode resumir, grosso modo, a uma teoria das normas jurídicas especificamente voltadas à

\footnotetext{
${ }^{5}$ Sem olvidar que tal autorregulação também denota a fiscalização e policiamento de práticas éticas pelos próprios agentes do mercado, levados a cabo pelas Bolsas de Valores, conforme esclarece EIZIRIK, Nelson Laks. Regulação e auto-regulação do mercado de valores mobiliários. Revista de Direito Mercantil, Industrial, Econômico, Financeiro, São Paulo, n. 48, p. 52, 1982.

${ }^{6}$ SZTAJN, Rachel. Regulação e o mercado de valores mobiliários. Revista de Direito Mercantil, Industrial, Econômico e Financeiro, São Paulo, v. 53, n. 135, p. 138, jul./set. 2004.

${ }^{7}$ Hart denomina de "regras secundárias" aquelas que investem os órgãos jurídicos de competência para criar regras (HART, Herbert L.A. O conceito de direito. Trad. Antonio de Oliveira Sette-Câmara. São Paulo: Martins Fontes, 2009. p. 122). Bobbio chama de "normas de estrutura", que são "normas para produção de outras normas." (BOBBIO, Norberto. Teoria geral do direito. Trad. Denise Agostinetti. São Paulo: Martins Fontes, 2008. p. 197). Já Alf Ross as denomina de "normas de competência". (ROSS, Alf. Direito e justiça. Trad. Edson Bini. 2. ed. São Paulo: Edipro, 2007. p. 76).
} 
regulação do mercado. Sendo assim, suas indagações serão centradas em questões como constitucionalidade ou legalidade das normas regulatórias, das relações jurídicas entre Estado e agente econômico, ou da averiguação de fatos jurídicos ensejadores de incidência normativa.

Obviamente a visão meramente estruturalista, embora importantíssima e altamente útil à análise do fenômeno, não é suficiente para a compreensão da regulação do mercado de capitais ou dos limites do poder do seu órgão regulador, devendo aliar-se a uma visão funcionalista do Direito, que trataremos a seguir. Firmar tais premissas, entretanto, mostrase necessário para o desenvolvimento deste trabalho, que se utilizará de categorias normativas no seu decorrer.

\section{b) Função:}

A função do Direito, conforme já aventado, é regular condutas intersubjetivas, restringindo a ação humana por meio de obrigações, proibições e permissões. Os chamados modais deônticos, que logicamente se limitam a essas três possibilidades (princípio do quarto excluído) operam, principalmente, pelas normas que dispõem comportamentos a serem cumpridos, pelas normas que punem o seu descumprimento, e pelas que premiam a sua observância.

Cumpre perceber que o Direito nada mais é que um sistema que incentiva os indivíduos a adotarem os comportamentos desejados pelo legislador. Tais incentivos ocorrem principalmente pela existência de sanções, i.e., punições ou prêmios criados pelo legislador e aplicados pelo executivo e, principalmente, pelo judiciário, que funcionam como condicionamentos lógicos e psicológicos aos indivíduos.

A função clássica da sanção, qual seja, a punitiva, passou a dividir espaço com o que Norberto Bobbio ${ }^{8}$ denominou de "função promocional" do Direito, que nada mais é do que sanções positivas ou premiais, i.e., recompensas conferidas pelo Estado às condutas por ele desejadas e cumpridas pelos cidadãos.

No que tange ao mercado de capitais, os exemplos são muitos. Tem-se sanções punitivas, desde multas aplicadas pela CVM, passando por suspensões, inabilitações, cassações, proibições, até penas de reclusão, no caso de crimes contra o mercado de

${ }^{8}$ BOBBIO, Norberto. Da estrutura à função: novos estudos de teoria do direito. Trad. Daniela Becaccia Versiani. Barueri/SP: Manole, 2007. p. 1-32. 
capitais. Prêmios também são conferidos, como ocorre, por exemplo, com as empresas que aderem e adaptam-se ao denominado "Novo Mercado", cuja recompensa é uma espécie de "selo de qualidade", que denota boas práticas de governança corporativa. As consequências econômicas advindas dessa sanção positiva podem, inclusive, vir na forma de valorização das ações.

Tal função reguladora, contudo, é apenas um instrumento para a consecução dos objetivos ou fins, mediatos e imediatos que o legislador, em sentido amplo, almeja alcançar.

\section{c) Objetivos:}

Se a regulação estatal se dá por intermédio de normas que regulam o comportamento dos agentes em um dado mercado, sua razão de ser deve-se aos objetivos pretendidos pelo legislador.

Toda a regulação da conduta, por assim dizer - seja em situações de mercado, seja em situações de não mercado (v.g., casamento, sucessão, regime de servidores públicos, etc.), sempre visa à consecução de fins - que, em última instância, é a conexão entre o mundo dos valores e o mundo dos fatos, ou seja, comportamentos que atendem àquelas máximas que alicerçam o mundo social e o mundo jurídico. Se o legislador coíbe o crime e a fraude, é porque pretende atingir a segurança, o bem-estar e a paz social.

Tais fins ou objetivos podem ser vistos sob dois aspectos: objetivos imediatos e objetivos mediatos.

Na regulação do mercado de capitais, os objetivos mediatos são aqueles usualmente normatizados pelos reguladores e abordados pelos doutrinadores que se debruçam sobre o tema. Por exemplo, "práticas equitativas" no mercado e o "acesso à informação" são frequentemente tratados nesse contexto. Para tanto, a regulação é criada e legitimada quando se verifica, conforme uma das teorias que serão discorridas a seguir, as chamadas falhas de mercado, ineficiências que o sistema econômico por si só não seria capaz de solucionar, cabendo então ao Estado - por meio de normas - corrigir tais desvios. No caso do mercado de capitais, a falha de mercado mais frequente é a denominada "assimetria de informação". 
Todavia, ao final do horizonte encontram-se valores mais fundamentais e essenciais, que são comuns a todos os fins pretendidos pelo Direito. Se o regulador do mercado pretende, de forma imediata, corrigir determinada falha de mercado, é porque, em última análise, deseja obter um ambiente justo, equânime de oportunidades para que os agentes possam interagir de forma a eles próprios gerarem bem-estar social.

São justamente esses valores últimos, que consubstanciam a própria finalidade mor e justificação de existência do Direito, que servirão também para julgar a correição das normas que regulam o mercado. A justiça, valor de natureza mais moral do que jurídica, é objetivada nos princípios que alicerçam o Direito: a segurança jurídica, a isonomia e o devido processo, dentre outros. É à luz desses mandamentos supremos que a regulação da vida humana, incluída nesta o segmento chamado "mercado de capitais", poderá ser considerada legítima ou não.

Portanto, os limites do poder normativo da Comissão de Valores Mobiliários, tema dessa dissertação, deverão ser examinados no que se refere tanto à sua estrutura normativa, quanto à função que essa regulação exerce e, por fim, quanto aos objetivos mediatos e imediatos que pretendem alcançar.

Com base nessas premissas, buscaremos então desenvolver a nossa exposição.

\subsection{Regulação e mercado de capitais}

A regulação, como acima mencionado, busca, em última análise, ordenar comportamentos por meio de normas jurídicas.

As normas são, portanto, elaboradas de forma a orientar as condutas das pessoas no sentido de alinhá-las com os objetivos traçados pelo Estado. O Estado, para isso, regula condutas que incidem desde o comportamento de cada indivíduo no seu dia a dia, como o caso da obrigatoriedade do uso de cinto de segurança, até o comportamento das sociedades e de como elas atuam, a exemplo das normas contidas na Lei das Sociedades Anônimas.

A regulação sempre significa, nesse sentido, uma interferência do Estado na vida humana. Ainda que nosso próprio modo de viver já leve em consideração as regras de conduta que juntas formam o arcabouço institucional, nossa liberdade é constantemente limitada pela regulação que o Estado sobre nós exerce. Já a regulação no mercado tem 
sentido mais restrito, referindo-se a uma forma de intervenção estatal diretamente no setor econômico. Em tal domínio, conforme leciona Vital Moreira, regulação é "o estabelecimento e a implementação de regras para a atividade económica destinadas a garantir o seu funcionamento equilibrado, de acordo com determinados objectivos públicos"9.

A competência que confere ao Estado o papel de interventor na ordem econômica está disposta no artigo 174, da Constituição Federal, que determina que "como agente normativo e regulador da atividade econômica, o Estado exercerá, na forma da lei, as funções de fiscalização, incentivo e planejamento, sendo este determinante para o setor público e indicativo para o setor privado."

Cumpre notar que tanto o vocábulo "regulação" quanto a expressão "intervenção estatal" não são isentos de vagueza e indeterminação semântica. Quanto às diversas acepções de regulação, preleciona Vital Moreira:

(a) em sentido amplo, é toda forma de intervenção do Estado na economia, independentemente dos seus instrumentos e fins; (b) num sentido menos abrangente, é a intervenção estadual na economia por outras formas que não a participação directa na atividade económica, equivalendo portanto, ao condicionamento, coordenação e disciplina da actividade económica privada; (c) num sentido restrito, é somente o condicionamento normativo da actividade económica privada (por via de lei ou outro instrumento normativo).

Já quanto às formas de intervenção, Eros Roberto $\mathrm{Grau}^{10}$ as distingue em: (a) intervenção por absorção ou participação, que ocorre quando a organização estatal assume - parcialmente ou não - ou participa do capital de unidade econômica que detém o controle patrimonial dos meios de produção e troca; (b) intervenção por direção, que se verifica quando a organização estatal passa a exercer pressão sobre a economia, estabelecendo mecanismos e normas de comportamento compulsório para os sujeitos da atividade econômica; (c) intervenção por indução, que se manifesta quando a organização estatal passa a manipular o instrumental de intervenção em consonância e na conformidade das leis que regem o funcionamento do mercado.

Pelas premissas adotadas nesse trabalho, nossa concepção de regulação envolve toda intervenção estatal que não envolva a participação do Estado como agente

\footnotetext{
${ }^{9}$ MOREIRA, Vital. Auto-regulamentação profissional e administração pública. Coimbra: Almedina, 1997. p. 34. ${ }^{10} \mathrm{GRAU}$, Eros Roberto. O direito posto e o direito pressuposto. São Paulo: Malheiros Ed., 1996. p. 171-172.
} 
econômico, mas sim como ponente de normas que coordenem o comportamento dos demais agentes. ${ }^{11}$

Destarte, a regulação é sinônimo de intervenção estatal no sentido normativo, que busca criar incentivos para que os agentes econômicos tomem decisões maximizadoras do bem-estar social. ${ }^{12}$ Estes agentes, que agem dentro de uma lógica de incentivos e custos, serão por eles influenciados ao realizarem suas escolhas.

O Direito, portanto, por meio de suas normas, intervém no mercado de diversas formas. Seja o direito concorrencial, quando o que se procura regular é a concentração no mercado de forma a garantir a livre concorrência e livre iniciativa; o direito tributário por meio da extrafiscalidade incentivando comportamentos; ou o direito do mercado de capitais, que dentre suas finalidades salientamos o full disclosure e a coibição de práticas não equitativas.

A necessidade ou justificativa para intervir no mercado ocorre, consoante o pensamento econômico tradicional, para corrigir desvios que o sistema de preços, por si só, não resolve. ${ }^{13} \mathrm{Na}$ maior parte das vezes o autointeresse racional dos indivíduos acarreta o bem-estar social, pela lógica da mão invisível. Entretanto, em determinadas situações, tal bem-estar social não é logrado por esse autointeresse, ocasionando o que se denominou de "falhas de mercado", conforme veremos adiante. Podemos adiantar, todavia, que estas falhas são, guardadas as distinções e discordâncias entre as teorias econômicas que serão abordadas a seguir, o motor primordial da regulação.

\subsubsection{Regulação e Economia: breves comentários}

Quando se trata de intervenção do Estado no mercado, as causas e as justificativas são invariavelmente econômicas. Daí a importância de abordarmos, ainda que de forma superficial, as principais correntes da ciência econômica que trataram do problema, não

\footnotetext{
${ }^{11}$ De forma bastante objetiva, Roger G. Noll define regulação como: "all levels of government attempt to control some private-sector economic decisions to which the government is not a party." NOLL, Roger G. Regulatory policy and the social sciences. Berkeley: University of California Press, 1985. p. 9-10.

${ }^{12}$ PINHEIRO, Armando Castelar; SADDI, Jairo. Direito, economia e mercados. Rio de Janeiro: Elsevier, 2005. p. 254-255.

${ }^{13}$ Cf. S. Breyer: "The justification for intervention arises out of an alleged inability of the market-place to deal with particular structural problems." (grifo do autor) "Typical Justifications for Regulation." In: BREYER, S. Typical Justifications for regulation. In: BALDWIN, Robert; SCOTT, Colin; HOOD, Christopher (Orgs.). A Reader on regulation. New York: Oxford University Press, 1998. p. 59.
} 
apenas por sua óbvia importância teórica como também pelo fato de exercerem grande influência na formação de políticas públicas, assim como o próprio pensamento jurídico a respeito do tema.

\section{a) Teoria Positiva da Regulação ou Teoria do Interesse Público:}

A análise normativa como uma teoria positiva ${ }^{14}$ foi a teoria da regulação predominante até início da década de 1960. Esta teoria tem as imperfeições concorrenciais como elementos motivadores da ação regulatória governamental. Pressupõe que os legisladores e reguladores são maximizadores do bem-estar social, buscando corrigir problemas de falhas de mercado.

As principais falhas de mercado consideradas pela Teoria Positiva são o monopólio natural e as externalidades. ${ }^{15}$ Afora estas duas falhas de mercado, questões como assimetria de informação e insuficiente provisão de bens públicos foram acrescentadas como justificativas para a intervenção regulatória do Estado. Portanto, segundo esta linha, a regulação vem para, na presença das falhas de mercado, assegurar que o resultado da interação entre os agentes econômicos seja eficiente. Nesse sentido, os agentes públicos agem, ao oposto dos agentes privados, de forma desinteressada, com o fito exclusivo de garantir o bom funcionamento do mercado. ${ }^{16}$

Tal linha de pensamento, conforme Posner ${ }^{17}$, sustenta todo o arcabouço regulatório, porém, originalmente elaborada com os pressupostos que os mercados seriam extremamente frágeis e que a regulação governamental não teria custos. Posteriormente, lembra o jurista da Universidade de Chicago, argumentou-se que a regulação pode ser um remédio pior que a doença, ou seja, que as agências não seriam competentes para lidar com

\footnotetext{
${ }^{14}$ Chamada por Paul L. Joskow e Roger G. Noll de normative analysis as a positive theory (NPT). PELTZMAN, Sam. The economic theory of regulation after a decade of deregulation. In: BALDWIN, Robert; SCOTT, Colin; HOOD, Christopher (Orgs.). A reader on regulation. New York: Oxford University Press, 1998. p. 95.

${ }^{15}$ BARRIONUEVO FILHO, Arthur; LUCINDA, Cláudio Ribeiro de. Teoria da regulação. In: BIDERMAN, Ciro; ARVATE, Paulo (Orgs.). Economia do setor público no Brasil. 6. reimp. Rio de Janeiro: Elsevier, 2004. p. 48-51.

${ }^{16} \mathrm{Cf}$. Robert Baldwin e Martin Cave, "public interest theories centre on the idea that those seeking to institute or develop regulation do so in pursuit of public interest related objectives (rather than group, sector, or individual self-interests). Proponents of regulation thus act as agents for the public interest. BALDWIN, Robert; CAVE, Martin. Understanding regulation: theory, strategy, and practice. New York: Oxford University Press, 1999. p. 19.

${ }^{17}$ POSNER, Richard. A. Teorias da regulação econômica. In: MATTOS, Paulo; PRADO, Mariana Mota; ROCHA, Jean Paul Cabral Veiga da; COUTINHO, Diogo R.; OLIVA, Rafael (Orgs.). Regulação econômica e democracia: o debate norte-americano. São Paulo: Ed. 34, 2004. p. 50.
} 
as falhas de mercado. ${ }^{18}$ Sendo assim, ainda que coubesse ao governo intervir, a correção seria pouco eficiente por decorrência de limitações dos órgãos reguladores.

Seja como for, percebe-se que tal teoria, ainda que criticada e mesmo tendo sofrido mutações ao longo dos anos, segue como sendo o estopim da regulação. ${ }^{19}$ Economistas influentes, como, por exemplo, Paul Krugman ${ }^{20}$, Nobel de Economia, advogam a necessidade de correção de falhas de mercado pelo governo como algo pacífico, sem desconhecer, no entanto, os problemas levantados pela teoria econômica de Stigler, que veremos a seguir, bem como as contribuições da Escolha Pública.

\section{b) Teoria Econômica da Regulação:}

Em 1971, George Stigler, economista da Universidade de Chicago, publicou o artigo The Theory of Economic Regulation, no qual é apresentada a ideia de que a regulação é adquirida pela indústria, e é desenhada e operada principalmente em seu benefício. $^{21}$ Com isso, nasce a denominada Teoria Econômica da Regulação (Economic Theory of Regulation - ET). ${ }^{22}$

Para Stigler, os agentes políticos são presumidamente maximizadores autointeressados, ou seja, buscarão sempre maximizar seu bem-estar. Sendo assim, suas decisões, que resultam na criação de normas jurídicas reguladoras do mercado, não são tomadas com vistas a atender ao interesse público ou da coletividade, mas sim aos seus próprios interesses. ${ }^{23}$

A forma de ver o problema mudou diametralmente. O paradigma do Estado benevolente corretor de desvios ocasionados pela inaptidão do mercado em corrigir suas próprias deficiências passou a ser severamente questionado, uma vez que a lógica do autointeresse racional seria então plenamente aplicável ao próprio governo. Segundo as palavras do próprio Stigler $^{24}$, em seu seminal texto:

\footnotetext{
${ }^{18}$ POSNER, Richard. op. cit., p. 51.

${ }^{19}$ Cf. PINHEIRO, Armando Castelar; SADDI, Jairo. op. cit., p. 283.

${ }^{20}$ KRUGMAN, Paul; WELL, Robin. Introdução à economia. Trad. Helga Hoffman. São Paulo: Campus, 2007. p. 3.

${ }^{21}$ STIGLER, George. A teoria da regulação econômica. In: MATTOS, Paulo; PRADO, Mariana Mota; ROCHA, Jean Paul Cabral Veiga da; COUTINHO, Diogo R.; OLIVA, Rafael (Orgs.). Regulação econômica e democracia: o debate norte-americano, cit., p. 23.

${ }^{22}$ PELTZMAN, Sam. op. cit., p. 93.

${ }^{23}$ Cf. BARRIONUEVO FILHO, Arthur; LUCINDA, Cláudio Ribeiro de. op. cit., p. 51.

${ }^{24}$ STIGLER, George. op. cit., p. 36.
} 
A indústria que procura poder político deve dirigir-se ao revendedor apropriado, o partido político. Este partido tem custos de operação, custos para manter uma organização e custos para competir em eleições. Esses custos do processo político são vistos de forma excessivamente limitada pela literatura sobre o financiamento das eleições: eleições são para o processo político aquilo que comercialização é para o processo de produção de uma mercadoria, um passo final essencial. O partido mantém sua organização e seu apelo eleitoral pela execução de serviços de grande valia para o eleitor, não somente antes das eleições, mas o tempo todo.

Consoante essa linha, grupos de interesse privados se aproveitariam do poder coercivo e regulatório do Estado para formular legislações que os beneficiem, uma vez que a mesma lógica que rege o mercado também se aplica ao processo político. Trata-se de uma aplicação dos preceitos da Teoria da Escolha Pública (Public Choice Theory), previamente desenvolvida em pioneiras e influentes obras de Kenneth Arrow (Social Choice and Individual Values, de $1951^{25}$ ), James Buchanan e Gordon Tullock (The Calculus of Consent, de $1962^{26}$ ) e de Mancur Olson (The Logic of Collective Action, de $1965^{27}$ ). Para os pugnadores da Escolha Pública, assim como há falhas de mercado, há também - de forma frequentemente mais danosa à sociedade - falhas de governo. ${ }^{28}$

Em outras palavras, tais grupos de interesse "capturam" o governo, e, por decorrência, também as agências reguladoras especializadas. ${ }^{29}$ Os políticos e funcionários públicos são também indivíduos igualmente autointeressados e, portanto, operam pela

\footnotetext{
${ }^{25}$ Trabalho inaugurador da Teoria da Escolha Social, extremamente influente nas décadas seguintes no que tange a questões como paradoxos de votação e de agregação de preferências individuais e coletivas. Dele vem o famoso "teorema geral da impossibilidade", pelo qual as preferências individuais, em votações democráticas, violam postulados básicos da racionalidade, como as preferências transitivas, culminando na conclusão simples, mas forte, de que preferências individuais não podem ser agregadas em preferências coletivas, em sistemas democráticos. Na edição espanhola, ARROW, Kenneth J. Elección social y valores individuales. Trad. Eusebio Aparicio Aufion. Barcelona: Planeta Agostini, 1994.

${ }^{26}$ Livro que estabeleceu os conceitos fundamentais da Escolha Pública. Na edição argentina: BUCHANAN, James; TULLOCK, Buchanan. El cálculo del consenso. Trad. Javier Salinas Sanchez. Buenos Aires: Editorial Planeta Agostini, 1993.

${ }^{27}$ Mancur Olson, em sua obra The logic of collective action: public goods and the theory of groups. Cambridge: Harvard University Press, 1965, demonstra que em regimes democráticos o suposto governo da maioria muitas vezes é dominado por pequenas minorias que concentram o poder, ou seja, grupos de interesse organizados.

${ }^{28}$ Afora a captura, podemos também citar outras falhas de governo, conforme elenca José Marcelo Martins Proença: juridificação, que significa excesso de normas; princípios motores distintos entre Direito e mercado; interesses próprios dos membros e dirigentes dos órgãos reguladores, em desvio às finalidades para as quais foram instituídos; grupos de pressão ou grupos de interesse; poder da burocracia, que pode conduzir à criação de medidas que atendem preferências dos órgãos reguladores ou de grupos de interesse, cujos resultados não seriam plenamente legítimos. Insider Trading. Regime Jurídico do uso de informaçães privilegiadas o mercado de capitais. São Paulo: Quartier Latin, 2005, p. 156-157.

29، The ET was born in a wave of enthusiasm for the notion that regulatory agencies are captured by producers." PELTZMAN, Sam. op. cit., p. 124.
} 
mesma escolha racional $^{30}$ que rege o comportamento dos agentes no mercado. $\mathrm{O}$ seu mercado, no entanto, tem por moeda o voto - em vez de uma competição por dinheiro, uma competição por poder. ${ }^{31}$ A regulação, por esse prisma, se dá não para corrigir falhas de mercado, mas sim para beneficiar interesses próprios da indústria e do governo. ${ }^{32}$

\subsubsection{Por que regular o mercado de capitais?}

Cabe, no presente tópico, aplicar o pensamento funcionalista e institucionalista ao Direito, ou seja, compreender as razões que levam à regulação do mercado de capitais. Em uma estrutura institucional, o que significa dizer um sistema social alicerçado por normas sociais e normas jurídicas, que formam as instituições informais e formais, respectivamente, as regras de conduta objetivas e estáveis possibilitam o ambiente seguro para as trocas econômicas. Instituições adequadas exercem papel fundamental no desenvolvimento econômico, reduzindo incertezas e guiando a interação humana, conforme aponta Douglas North. ${ }^{33}$

Instituições formais denotam regras jurídicas e, mais precisamente, direitos de propriedade, os mais claros e objetivos possíveis, de modo que haja a necessária certeza do Direito. Em um mundo onde os custos de transação são altos, vale dizer, onde os custos em que as partes incorrem no processo de efetivação de uma negociação ${ }^{34}$, as instituições fazem toda a diferença. Os direitos de propriedade, claros na legislação e aplicados coercivamente pelos tribunais reduzem os custos de transação - custos de procura, de negociação e de cumprimento dos contratos - permitindo uma alocação eficiente de recursos escassos e, portanto, permitindo criação de riqueza e bem-estar social.

\footnotetext{
${ }^{30}$ Teoria que alicerça o pensamento econômico há séculos, segundo a qual os indivíduos são autointeressados e maximizadores do próprio bem-estar, calculam o custo-benefício de suas escolhas e reagem a incentivos. Nesse sentido: KRUGMAN, Paul; WELL, Robin. op. cit., p. 211.

${ }^{31}$ Cf. BALDWIN, Robert; CAVE, Martin. op. cit., p. 21.

${ }^{32}$ Cf. Marver H. Bernstein: "Unreality begins to creep in, however, as soon as it appears that the commission's enabling statute may in fact provide only the most general guide to the goals of regulatory policy. Left largely to its own resources, which are apt to be wick relative to the strengths of the organized parties, a commission will probably be guided by dominant interests in the regulated industry in its formulation of the public interest. Thus the public interest may become more private than public." BERNSTEIN, Marver H. Regulating business by independent commission. New Jersey: Princeton University Press, 1955. p. 154.

${ }^{33}$ NORTH, Douglas. Institutions, institutional change and economic performance. Cambridge: Cambridge University Press, 1990. p. 3.

${ }^{34}$ MANKIW, N. Gregory. Princípios de microeconomia. 3. ed. Trad. Allan Vidigal Hastings. São Paulo: Pioneira Thomson Learning, 2005. p. 211.
} 
Todavia, há situações, como vimos linhas atrás, em que o mercado não tem incentivos para uma eficiente alocação de recursos. Nesses casos, verificam-se falhas de mercado, que, em tese, requerem intervenção do Estado para corrigi-las. Já mencionamos as falhas em tópico anterior, mas cabe agora defini-las.

(a) Monopólio: ocorre quando um produtor/vendedor concentra todo o mercado para si, criando barreiras à entrada de outros vendedores, e, portanto, impedindo o equilíbrio entre oferta e demanda. ${ }^{35}$ Outras formas de concentração, como oligopólios e cartéis também ilustram esse problema, cujas consequências danosas são várias, como, por exemplo, a cobrança de preços abusivos. Órgãos de proteção da concorrência, como o Conselho Administrativo de Defesa da Concorrência (CADE), buscam coibir tais concentrações de mercado.

(b) Externalidades: quando custos não previstos pelas partes em uma transação atingem terceiros externos a ela. O exemplo mais comum é o da fábrica que polui o meioambiente, gerando um custo social não internalizado no custo de seus produtos. Diversas medidas estatais podem ser tomadas para "internalizar" essas externalidades, como, por exemplo, os tributos extrafiscais sobre a poluição. ${ }^{36}$

(c) Bens Públicos: aqueles bens que são de uso não rival e não exclusivo. Uso não rival significa que o uso de um bem por um indivíduo não reduz a sua quantidade ao ser utilizado por outrem. Uso não excludente quer dizer que não se pode impedir o uso do bem pelas pessoas. Por tais características, torna-se difícil cobrar por esse bem, o que desincentiva o mercado a ofertá-lo. ${ }^{37}$ Exemplos dessa espécie de bem são a iluminação pública e a segurança pública. Uma forma de o Estado corrigir tal falha é simplesmente ele próprio oferecer esses bens à população.

(d) Assimetria de informação: ocorre quando uma das partes sabe mais sobre o produto do que a outra parte envolvida na transação, implicando trocas não equitativas e prejudicando a tomada eficiente de decisões. ${ }^{38}$ O Estado deve intervir para obrigar, por intermédio de normas, a transparência nas trocas econômicas.

\footnotetext{
${ }^{35}$ PINDICK, Robert S., RUBINFELD, Daniel L. Microeconomia. Trad. Eleutério Prado. São Paulo: Prentice Hall, 2002.p. 679.

${ }^{36}$ HARRISON, Jeffrey L. Law and economics in a nutshell. Sain Paul: Wesley \& Co, 1995. p. 42.

${ }^{37}$ COOTER, Robert D.; ULEN, Thomas. Law and economics. New York: Addison Wesley, 2002. p. 40.

${ }^{38}$ CLEAVER, Tony. The basics economics. London: Routledge, 2004. p. 198.
} 
Lembrando das advertências de Stigler, as correções por meio de intervenção estatal devem ser levadas com o máximo cuidado, visto que o Estado não costuma ser o melhor alocador de recursos. Todavia, em situações onde há assimetria de informação, remédios jurídicos devem ser instaurados para coibir transações em que uma das partes injustamente leva vantagem sobre a outra, práticas que a longo prazo minam a própria possibilidade de mercado livre, inclusive no mercado de capitais. ${ }^{39}$

O mercado de capitais, por viabilizar a capitalização e o consequente crescimento das empresas, é visto por muitos como sinônimo de desenvolvimento. ${ }^{40}$ É em seu ambiente que ocorre a troca entre companhias abertas que necessitam de recursos financeiros e investidores que possuem recursos financeiros excedentes e querem aplicá-los de maneira rentável a fim de aumentar seu capital.

A sua estrutura é composta por um conjunto de mercados, instituições e ativos que viabiliza a transferência de recursos entre tomadores e aplicadores. Ou seja, o mercado de capitais nada mais é do que um ambiente institucional formado por um conjunto de pessoas, onde a mobilização de poupança é realizada diretamente entre a entidade emissora e investidor. ${ }^{41}$

Para que estas trocas ocorram da melhor forma possível, a primeira grande necessidade é o amplo acesso à informação. ${ }^{42}$ Ou seja, ao se reduzir ao máximo possível a assimetria de informação, se logrará reduzir também os custos de $\operatorname{transação~}^{43}$ e,

\footnotetext{
${ }^{39} \mathrm{Cf}$. Susan Rose-Ackerman, "markets also frequently work poorly because information is imperfect and asymmetrical. ROSE-ACKERMAN, Susan. Efficiency, equity and inalienability. In: SCHULENBURG, J.M. Graf von der; SKOGH, G. (Orgs.). Law and economics \& the economics of legal regulation. Dordrecht: Martinus Nijhoff, 1986. p. 13.

${ }^{40}$ MAGLIANO FILHO, Raymundo. Mercado de capitais: desenvolvimento sustentável. In: ROCCA, Carlos Antonio (Org.). Revolução do mercado de capitais no Brasil: o crescimento recente é sustentável? 2. reimp. Rio de Janeiro: Elsevier, 2008. p. 3.

${ }^{41}$ EIZIRIK, Nelson; GAAL, Ariadna B.; PARENTE, Flávia; HENRIQUES, Marcus de Freitas. Mercado de capitais: regime jurídico. 2. ed. Rio de Janeiro: Renovar, 2008. p. 9.

42،“A relevância da regulação da informação no mercado de capitais justifica-se, portanto, no sentido de ser esta um meio eficaz de proteção do investidor, já que o habilita a tomar conscientemente, ao menos, em tese, as suas decisões de investimento.” PROENÇA, José Marcelo Martins. Insider trading: regime jurídico do uso de informações privilegiadas no mercado de capitais. São Paulo: Quartier Latin, 2005. p. 134.

${ }^{43} \mathrm{Em}$ artigo que lhe valeu o Nobel de Economia, The Market for Lemons: Quality Uncertainty and the Market Mechanism, de 1970, George Akerloff trata do problema da assimetria de informação em certos mercados, onde uma das partes sabe mais sobre o produto que a outra. O termo "lemon" (limão) seria o equivalente, em língua portuguesa, ao "abacaxi". O exemplo onde Akerloff aplica o seu modelo econômico é o de carros usados, típico mercado onde ocorre (ou ao menos costumava ocorrer de forma mais frequente) tal assimetria: os compradores seriam vítimas dessa falta de acesso à qualidade do automóvel que estavam adquirindo - daí o "abacaxi". Soluções para evitar tal tipo de falha de mercado podem ser minimizadas pela busca de informação pelos consumidores, ou pelo próprio mercado, como vem ocorrendo nos últimos anos, quando automóveis usados também são vendidos com garantia para defeitos mecânicos. A regulação justificase, também, ao impor regras jurídicas que obriguem os comerciantes a fornecer a garantia. In: GOLDBERG, Victor. Readings in the economics of contract law. Cambridge: Cambridge University Press, 1982.
} 
consequentemente, aumentar a eficiência, confiabilidade e segurança do mercado. $^{44}$

Percebe-se, portanto, que a falha de mercado por excelência que atinge este setor é a assimetria de informação.

Com isso, por meio da regulação, teremos normas obrigando os agentes do mercado a divulgarem uma série de informações que o regulador entenda necessárias para garantir a transparência das operações. Note-se que a intervenção estatal, por meio de normas jurídicas, busca suprir essa falha de mercado, obrigando os seus agentes, para tanto, a cumprir regras.

A Lei n. ${ }^{\circ} 6.385 / 1976$ dispõe, em seu artigo $4^{\circ}$, sobre os objetivos pretendidos pela regulação no mercado de capitais:

Art . 4 ${ }^{\circ} \mathrm{O}$ Conselho Monetário Nacional e a Comissão de Valores Mobiliários exercerão as atribuições previstas na lei para o fim de:

I - estimular a formação de poupanças e a sua aplicação em valores mobiliários;

II - promover a expansão e o funcionamento eficiente e regular do mercado de ações, e estimular as aplicações permanentes em ações do capital social de companhias abertas sob controle de capitais privados nacionais;

\footnotetext{
${ }^{44} \mathrm{Um}$ dos nomes mais importantes entre os economistas contemporâneos no que se refere ao tema assimetria da informação é Joseph Stiglitz, que, não por coincidência, dividiu o Nobel com Akerloff. Em seu discurso ao receber a láurea, Stigliz expõe que tal falha não é resolvida pelo mercado, acarretando custo social, ou seja, perda de bem-estar da coletividade, colacionando interessante exemplo aplicado ao mercado de capitais. Não obstante ser longa, a transcrição vale ser feita pelo seu forte caráter ilustrativo:

"Early work, already referred to, had laid the foundations for the idea that economies with information imperfections would not be Pareto efficient, even taking into account the costs of obtaining information. There were interventions in the market that could make all parties better off. We had shown, for instance, that incentives for the disclosure and acquisition of information were far from perfect; imperfect appropriability meant that there might be insufficient incentives, but the fact that much of the gains were "rents," gains by some at the expense of others, suggested that there might be excessive expenditures on information. One of the arguments for unfettered capital markets was that there were strong incentives to gather information; if one dis-covered that some stock was more valuable than others thought, if you bought it before they discovered the information, then you would make a capital gain. This price discovery function of capital markets was often advertised as one of its strengths. But the issue was, while the individual who dis-covered the information a nano-second before any one else might be better off, was society as a whole better off: if having the information a nano-second earlier did not lead to a change in real decisions (e.g. concerning investment), then it was largely redistributive, with the gains of those obtaining the information occurring at the expense of others. Another example illustrates what is at issue. Assume hundred dollar bills were to fall, one each at the left foot of each student in my class. They could wait to the end of the lecture, then pick up the money; but that is not a Nash equilibrium. If all students were to do that, it would pay any one to bend down and quickly scoop up what he could. Each realizing that immediately picks up the dollar bill at his foot. The equilibrium leaves each no better off than if he had waited - and there was a great social cost, the interruption of the lecture." STIGLIZ, Joseph. Nobel Prize Lecture. Disponível em: <http://www.nobelprize.org/nobel_prizes/economics/laureates/2001/stiglitz-lecture.pdf>. Acesso em: 10 nov. 2011.
} 
III - assegurar o funcionamento eficiente e regular dos mercados da bolsa e de balcão;

IV - proteger os titulares de valores mobiliários e os investidores do mercado contra:

a) emissões irregulares de valores mobiliários;

b) atos ilegais de administradores e acionistas controladores das companhias abertas, ou de administradores de carteira de valores mobiliários;

c) o uso de informação relevante não divulgada no mercado de valores mobiliários. (Alínea incluída pela Lei $\mathrm{n}^{\circ} 10.303$, de 31.10.2001)

$\mathrm{V}$ - evitar ou coibir modalidades de fraude ou manipulação destinadas a criar condições artificiais de demanda, oferta ou preço dos valores mobiliários negociados no mercado;

VI - assegurar o acesso do público a informações sobre os valores mobiliários negociados e as companhias que os tenham emitido;

VII - assegurar a observância de práticas comerciais equitativas no mercado de valores mobiliários;

VIII - assegurar a observância no mercado, das condições de utilização de crédito fixadas pelo Conselho Monetário Nacional.

Os três primeiros incisos são claramente metas, finalidades a serem obtidas de forma programática, ou seja, standards norteadores das atividades do Conselho Monetário Nacional e da Comissão de Valores Mobiliários.

Todavia, a partir do inciso IV em diante, percebe-se maior objetividade. Embora não se tratem de regras de conduta destinadas aos agentes, as obrigações dos órgãos ficam mais claras. Note-se, ainda, que essas obrigações subsomem-se a duas questões fundamentais:

- Assegurar o acesso do público a informações sobre valores mobiliários negociados e sobre quem os tenha emitido - o chamado full disclosure, que, no dizer de Nelson Eizirik ${ }^{45}$, é um dos elementos fundamentais na regulação do mercado de capitais;

- Assegurar a observância de práticas comerciais equitativas no mercado de valores mobiliários.

Se a transparência total ou full disclosure é, por um lado, incentivada por meio de normas que impõem a divulgação de informações relevantes, é, por outro, estimulada por meio de normas que punem aqueles que atuam em situação de vantagem em relação aos demais agentes, por meio da coibição de práticas não equitativas.

${ }^{45}$ EIZIRIK, Nelson Laks. op. cit., p. 48. 
$\mathrm{Na}$ classificação corrente de falhas de mercado pela literatura econômica, a assimetria de informação é simplesmente elencada dentre as demais. Mas qual a sua razão de existir?

Como bem ressalta Luigi Zingales ${ }^{46}$, a informação tem características de bem público, outra falha de mercado. Nesse sentido, não há incentivos para que o setor privado produza informação em nível ótimo, ou seja, de acordo com a sua demanda, considerando que por ser de uso não rival e não excludente, não há retorno em relação ao custo para produzi-la. Considerando que as falhas são inter-relacionadas, os bens públicos implicam externalidades positivas, que ocorrem quando os produtores desses bens não conseguem internalizar os benefícios auferidos por terceiros, arcando somente com o seu custo.

Ora, é naturalmente mais oportuno para o agente de mercado impedir o acesso a determinados dados, daí a necessidade de regras que obriguem a sua disponibilização aos demais agentes, ou de regras que impliquem em sanções positivas à transparência e governança corporativa - como ocorre com o Novo Mercado.

Há diversas possíveis quebras de transparência pelos agentes do mercado. Armando Castelar Pinheiro e Jairo Saddi ${ }^{47}$ exemplificam com o caso de emissões primárias de ações ou títulos de dívida corporativa, situações "em que a empresa sabe muito mais sobre sua verdadeira situação financeira do que os potenciais investidores".

Quando não há incentivos adequados - sejam os providos pelo mercado, sejam os impostos pelas normas jurídicas - pode ocorrer o chamado "risco moral", que é a tendência de o agente não monitorado agir de forma desonesta ou indesejável. ${ }^{48}$

Por outro lado, interessante perceber que a regulação e suas correspondentes sanções vêm, ao longo dos últimos anos, incentivando as empresas a adotar regras internas de compliance cada vez mais rígidas, de modo a praticar o que se convencionou denominar de "governança corporativa", cujas recompensas são de cunho econômico, e não apenas jurídico. Empresas que sinalizam transparência ao mercado terão suas ações potencialmente mais valorizadas ou tidas como mais seguras aos investidores. Aquelas que

\footnotetext{
${ }^{46}$ ZINGALES, Luigi. The future of securities regulation. Working Paper. Chicago Booth School of Economics, p. 6, 2009. Disponível em: <http://papers.ssrn.com/sol3/papers.cfm?abstract_id=1319648>. Acesso em: 12 nov. 2011.

${ }^{47}$ PINHEIRO, Armando Castelar; SADDI, Jairo. op. cit., p. 259.

${ }^{48}$ Cf. MANKIW, Gregory. op. cit, p. 499.
} 
querem abrir capital enfrentarão mais facilmente o processo penoso para tanto, quanto mais transparentes e cumpridoras de boas regras de governança corporativa ${ }^{49}$ forem.

Richard Posner aponta ${ }^{50}$ para o fato de os mercados de capitais serem altamente competitivos, o que também os faz gerar informação sobre os seus produtos. E isso acontece também por conta de o mercado contar com intermediários cada vez mais sofisticados (bancos de investimento, corretoras, especialistas) entre os vendedores e compradores, que ocasionam um círculo virtuoso nesse processo de transmissão de informação. Nesse diapasão, um mercado competitivo pode sim gerar os devidos incentivos para que o full disclosure ocorra espontaneamente, graças ao marco regulatório corretor de eventuais desvios e igualmente às demandas à informação pelos próprios agentes.

Com isso, conforme já dito, percebemos que um dos focos centrais da regulação no mercado de capitais é a informação. Seja por meio de normas que exijam sua ampla divulgação, ou por meio de outras normas que punam aqueles que não as divulgarem ou que delas façam uso indevido.

O outro motor importante da regulação, que é a observância a práticas comerciais equitativas, também é, em parte, conexa ao problema da informação. A manipulação de informações (v.g. boatos sobre situação financeira de empresas listadas) com fins de obtenção de vantagens, ou o uso ilícito de informações privilegiadas (insider trading), subsomem-se à mesma questão. ${ }^{51}$

Certamente a vedação a práticas não equitativas não se resume a isso, mas não há como negar essa conexão. Nesse sentido, é a colocação de L.G. Paes de Barros Leães, em seu clássico Mercado de Capitais \& Insider Trading ${ }^{52}$, ao advertir que o full disclosure não se esgota com a prestação de informações, mas opera no sentido de criar medidas assecuratórias de acesso às novas informações por investidores potenciais, de modo a impedir que administradores, altos funcionários e acionistas controladores utilizem-se impropriamente de informações a que têm acesso em primeira mão, por conta da posição que ocupam.

\footnotetext{
${ }^{49}$ Para estudo aprofundado sobre o tema, ver ROMANO, Roberta. Is regulatory competition a problem or irrelevant for corporate governance? Yale Law School Center for Law, Economics and Public Policy Research Paper, n. 307. Disponível em: <http://papers.ssrn.com/sol3/papers.cfm?abstract_id=693484>. Acesso em: 26 set. 2011.

${ }^{50}$ POSNER, Richard. Economic analysis of law. New York: Aspen 2002. p. 486.

${ }^{51}$ Cf. PROENÇA, José Marcelo Martins. op. cit., p. 136.

${ }^{52}$ LEÃES, L. G. Paes de Barros. Mercado de capitais \& insider trading. São Paulo: Ed. Revista dos Tribunais, 1982. p. 172-173.
} 
A imposição quanto à divulgação de informações cumpre, conforme visto no primeiro tópico desta dissertação, um objetivo imediato da intervenção da regulação no mercado. O objetivo mediato ou fim primordial, contudo, é promover um ambiente de trocas econômicas pautado pelos valores da isonomia entre os agentes, pela segurança jurídica e certeza do Direito. São esses os valores a serem alcançados pela intervenção reguladora no mercado de capitais brasileiro.

\subsubsection{O surgimento da regulação no mercado de capitais: da crise ao mercado de capitais regulado}

Pressuposto de um mercado é a troca entre agentes. Para que isso ocorra, é indispensável o encontro entre agentes com excedente, e agentes com falta de recursos. $\mathrm{O}$ detentor do excedente que se interessar por obter algum tipo de retorno poderá, mediante esta expectativa de retorno, transferi-lo para o agente que o necessita.

No entanto, como um grupo identifica o outro? Como sabemos quem possui excedente e quem necessita de recursos? Trata-se de um problema de informação. Há elevados custos de transação para se juntar estes dois grupos. Diante desta situação, é na Idade Média que surge a ideia do intermediário, ou seja, um agente responsável por juntar aqueles que possuem excedentes com aqueles que os necessitam.

Este intermediário, responsável pelo encontro das necessidades dos dois grupos, se mostrará ao mercado com dupla face, assim, "as operações são fechadas sempre com o intermediário financeiro, transformando o tomador do recurso em devedor do intermediário, e o detentor do excedente em credor deste mesmo intermediário". ${ }^{53} \mathrm{O}$ tomador, assim, capitalizará sua atividade por meio de endividamento.

Há, com isso, a redução da assimetria de informação e dos custos de transação de se procurar, no mercado, agentes para se realizar a transferência das riquezas. Isso porque as operações são fechadas sempre com o intermediário financeiro, transformando o tomador do recurso em devedor do intermediário, e o detentor do excedente em credor deste mesmo intermediário.

\footnotetext{
${ }^{53}$ Sobre o assunto ver: SATIRO, Francisco. Primeiras notas sobre mercado de capitais. In: SATIRO, Francisco. Mercado de capitais: aspectos jurídicos. São Paulo: Saraiva. No prelo.
} 
Trata-se, na economia de mercado, de função do sistema financeiro. A atribuição do papel de intermediário financeiro é conferido à instituição financeira, e será ela a responsável pela captação de recursos junto a agentes econômicos superavitários, para posterior empréstimo àqueles deficitários. ${ }^{54}$

Entretanto, com as grandes navegações houve a intensificação do fluxo mercantil, os valores necessários para que os comerciantes conseguissem levar a cabo suas atividades eram vultuosos, e o risco da atividade altíssimo. Com isso, deixou de ser interessante para os bancos envolverem-se nestas operações como disponibilizadores do crédito.

É assim que nasce a ideia de um mercado de desintermediação financeira, isto é, diferentemente do que se tinha em um primeiro momento com a presença da instituição financeira, se passa a ter um mercado no qual a mobilização da poupança é feita diretamente entre tomador e investidor, inexistindo, portanto, a figura da instituição financeira intermediando a operação. ${ }^{55}$ Adota-se, assim, um modelo no qual se outorga aos investidores do capital a qualidade de participantes do empreendimento, isto é, de sócios do tomador dos recursos.

O modelo de mercado composto por apenas três dos elementos básicos para sua existência, quais sejam, o investidor, a companhia e o ambiente de trocas, funcionou perfeitamente até início de século XX. Até então, o que se tinha era a concepção de Adam Smith e sua "mão invisível" sem a necessidade de intervenção estatal ou qualquer forma de regulação.

Entretanto, após a Revolução Industrial e a quebra da Bolsa de Nova Iorque, no ano de 1929, foi desencadeada uma crise institucional, em função da ausência de normas de ordem pública que regulassem a circulação dos valores mobiliários emitidos pelas sociedades anônimas. ${ }^{57}$

Como resposta, Franklin Roosevelt, presidente recém-eleito, encomenda um pacote de mudanças a fim de restabelecer o mercado de maneira geral. Assim nasce o New Deal, como uma série de programas econômicos implantados nos Estados Unidos entre os anos

\footnotetext{
${ }^{54}$ EIZIRIK, Nelson; GAAL, Ariadna B.; PARENTE, Flávia; HENRIQUES, Marcus de Freitas. op. cit., p. 2. ${ }^{55}$ Id. Ibid., p. 9.

${ }^{56}$ Expressão utilizada por Adam Smith para descrever a situação de uma economia de mercado que, apesar da inexistência de uma entidade coordenadora do interesse comum, apresenta interações dos indivíduos que parecem resultar numa determinada ordem, como se houvesse uma "mão invisível" que os orientasse.

${ }^{57}$ SALLES, Marcos Paulo de Almeida. Aspectos da competência do CMN e da CVM no mercado de valores mobiliários. Revista de Direito Mercantil, Industrial, Econômico e Financeiro, São Paulo, v. 36, n. 108, p.105, out./dez. 1997.
} 
de 1933 e 1936, como resposta à grande depressão. John Maynard Keynes, economista britânico, teve papel significativo nessa passagem. "Sua obra principal, a Teoria Geral do Emprego, do Dinheiro e do Juro, onde se teoriza sobre o papel da demanda como sustentadora do nível da atividade econômica, reintroduz o Estado dentro da Economia."58 (grifos do autor).

Seguindo nessa seara de ideias, abriu-se espaço para que o Estado, por meio da ampliação de suas competências, passasse a intervir de forma decisiva na ordem econômica e social, tornando-se em "órgão regulador e motor da economia." ${ }^{, 59} \mathrm{Com}$ isso, nasce nos Estados Unidos a percepção de que seria necessária a criação de agências governamentais cuja atuação seria decorrente da extensão do poder executivo, envolvendo inclusive a delegação de competência legislativa ${ }^{60}$, mas, entretanto, sem qualquer intervenção política. Um órgão autônomo, capaz de exercer uma função regulatória junto ao mercado de capitais. ${ }^{61}$

Esta ideia de intervenção direta do Estado como forma de institucionalizar o mercado passou a ser colocada em prática a partir de 1933 nos Estados Unidos ${ }^{62}$, por meio do Securities Act, cuja finalidade precípua era a de regular a circulação de valores mobiliários, chamados de securities. ${ }^{63}$ Posteriormente, em 1934, foi promulgado o

${ }^{58}$ LEÃES, L. G. Paes de Barros. op. cit., p. 13.

${ }^{59}$ Id. Ibid., p. 14.

${ }^{60}$ Segundo Marçal Justen Filho, "na etapa anterior ao New Deal, prevalecia o entendimento de Field v. Clark, no sentido de que o Congresso não poderia delegar sua competência legislativa. Isso não importava a impossibilidade de atribuir a outros órgãos governamentais a incumbência de produzir regulação legislativa. Mas as delegações tinham de ser limitadas em matéria e extensão. Poderiam abranger questões atinentes a negócios internacionais ou a gestão de bens públicos, sem alcançar a disciplina de relações jurídicas de que participassem os particulares. Depois, envolviam apenas matérias que não comportassem controvérsias ou divergências significativas. Em suma, a delegação era admitida especialmente em razão da ausência de conflituosidade entre sujeitos privados acerca dos temas abrangidos. Foi em 1943, em decisão do chamado Networks Case (National Broadcasting Company v. United States), "que reputou-se cabível delegar para a Federal Communications Commission - FCC poderes amplos e indeterminados para realização do bem comum. O núcleo da controvérsia envolvia a natureza dos poderes conferidos pela lei à agência." JUSTEN FILHO, Marçal. $O$ direito das agências reguladoras independentes. São Paulo: Dialética, 2002. p. 87-88.

${ }^{61}$ SZTAJN, Rachel; SALLES, Marcos Paulo de Almeida. Regulação e concorrência no sistema financeiro. Revista de Direito Mercantil, Industrial, Econômico e Financeiro, São Paulo, v. 40, n. 123, p. 41, jul./set. 2001.

${ }^{62}$ Ao todo, foram cinco novos diplomas que compuseram a regulação do mercado de valores mobiliários proposto pelo New Deal. Afora o Securities Act, de 1933 e o Securities and Exchange Act, de 1934, também foram publicados o Public Utility Holding Company Act, de 1935, que exigia que determinadas companhias fossem registradas na SEC; o Maloney Act, de 1938, que assentava o mercado de balcão sob supervisão da SEC; e o Glass-Steagall Banking Act, de 1933, que, entre outras medidas, separava as atividades típicas de banco comercial e as de banco de investimento. Apesar de não se aplicar diretamente ao mercado de valores mobiliários, o afetava fortemente. MCCRAW, Thomas K. Prophets of regulation. Cambridge: Harvard University Press, 1984. p. 169.

${ }^{63}$ Luiz Gastão Paes de Barros Leães define security como todo investimento em dinheiro ou em bens suscetíveis de avaliação monetária, realizado pelo investidor em virtude de uma captação pública de recursos, com vistas ao fornecimento de capital de risco a um empreendimento, em que ele, o investidor, não tem ingerência direta, mas do qual espera obter ganho ou benefício futuro -, revela-se impossibilitada. LEÃES, L. G. 
Securities and Exchange Act, dando origem a Securities and Exchange Comission (SEC), entidade encarregada da fiscalização do cumprimento das normas regulatórias tanto da legislação de 1934, quanto do Securities Act de $1933 .^{64}$

A SEC é uma agência reguladora federal independente ${ }^{65}$ que emite normas para interpretar e implementar as leis aprovadas pelo Congresso referentes ao mercado de capitais. Ela também executa e fiscaliza este conjunto de normas jurídicas ${ }^{66}$, agindo próximo ao mercado e atuando conjunturalmente. Sua missão, portanto, é a de proteger os investidores, mantendo justo, ordenado e eficiente o mercado, facilitando o acesso à informação. ${ }^{67}$ Trata-se de um órgão especializado, que age na elaboração de normas, e garante a eficiência e transparência no mercado.

Afora os programas relativos à transparência e aplicação de normas da Comissão, a agência também regula o mercado de valores mobiliários, com o fim de prevenir a ocorrência de transações não equitativas e também remover obstáculos para o seu desenvolvimento. Ademais, a SEC também regula corretoras e distribuidoras de valores mobiliários, gestores de investimentos, sociedades de investimento (investment companies) e public utility holding companies. Já nos processos de recuperação de empresas de capital aberto, a agência atua como consultora. ${ }^{68}$

A SEC, frequentemente classificada como a agencie estadunidense de maior sucesso $^{69}$, não apenas influenciou o Brasil a adotar um sistema semelhante (CVM), como também, dentre outros, a França (Comission des Opérations de Bourse - COB), a Itália (CONSOB - Comissione Nacionale per Società i Borsa) e a Argentina (CNV - Comissión Nacional de Valores). ${ }^{70}$

Paes de Barros. O conceito de 'security' no direito norte-americano e o conceito análogo no direito brasileiro. Revista de Direito Mercantil, Industrial, Econômico e Financeiro, São Paulo, n. 14, p. 57, 1974.

${ }^{64}$ MCCRAW, Thomas K. op. cit., p. 181.

${ }^{65} \mathrm{O}$ que são as independent regulatory agencies or commissions será assunto para o próximo capítulo. Entretanto, já adiantamos que, quanto ao âmbito de atuação, a SEC é dotada de poder normativo delegado pelo Congresso para estabelecer normas para a regulação econômica do mercado estadunidense. Além disso, possui também competência para dirimir conflitos intersubjetivos. Quanto ao critério da autonomia, refere-se ao grau de liberdade que possui em relação ao Poder Executivo no que se refere a seus dirigentes, que são protegidos por uma maior estabilidade, e cuja perda de cargo somente será admissível se concorrerem causas previstas expressamente em lei. JUSTEN FILHO, Marçal. op. cit., p. 64-69.

${ }^{66} \mathrm{CHOI}$, Stephen J.; PRITCHARD, A. C. Securities regulation: cases and analysis. New York: Foundation Press, 2005. p. 2.

${ }^{67}$ KARMEL, Roberta S. Regulation by prosecution: the securities \& exchange commission versus corporate america. New York: Simon and Schuster, 1982. p. 16.

${ }^{68}$ Id. Ibid., p. 38-39.

69"'The SEC, in the half-century since its creation in 1934, has often been cited as the most successful of all federal regulatory agencies." MCCRAW, Thomas K. op. cit., p. 153.

${ }^{70}$ SALLES, Marcos Paulo de Almeida. op. cit., p. 107. 


\subsubsection{Contexto histórico brasileiro}

A percepção da necessidade de regulação do mercado de capitais por meio de um órgão especializado teve no Brasil como principal motivo, de forma similar ao que ocorreu nos Estados Unidos, uma crise.

A história do mercado de capitais organizado no Brasil é muito recente. Foi no período pós-revolução de 1964, por meio do Programa de Ação Econômica do Governo, que começou a ser traçada a atual configuração do mercado de capitais brasileiro. ${ }^{71}$ Até então, o que se tinha era basicamente a disciplina dos Corretores de Bolsa e dos Bancos. As sociedades anônimas ainda eram regidas pelo antigo Decreto-Lei n. ${ }^{\circ}$ 2.627/1940.

O Programa de Ação Econômica do Governo, que buscava estabilizar e desenvolver a economia brasileira, era composto por um conjunto de propostas para reformular o sistema financeiro e de mercado de capitais. Dentre os diplomas legais que foram editados, salientamos, no ano de 1964, a Lei n. ${ }^{\circ}$ 4.595, que dispôs sobre a política e as instituições monetárias, bancárias e creditícias, bem como sobre a criação do Conselho Monetário Nacional (CMN) e do Banco Central do Brasil (BACEN). ${ }^{72}$

Seguindo esta mesma linha de estruturação, em 1965 é editada a Lei n. ${ }^{\circ}$ 4.728, a primeira legislação brasileira regulando o mercado de capitais e estabelecendo medidas para o seu desenvolvimento. Este diploma estabeleceu, em seu artigo $1^{\circ}$, que os mercados financeiro e de capitais seriam disciplinados pelo Conselho Monetário Nacional e fiscalizados pelo Banco Central do Brasil. No dispositivo seguinte, estabeleceu as finalidades a serem atendidas por estes órgãos no exercício de suas funções.

Entretanto, em que pese às medidas do governo para desenvolver o mercado de capitais brasileiro, as reformas de 1964 e 1965 não foram suficientes. Diante disso, em 1967, uma alternativa de cunho fiscal ${ }^{73}$ foi colocada em prática por meio da edição do Decreto-Lei n. ${ }^{0}$ 157, que concedia estímulos fiscais à capitalização das empresas, reforçava os incentivos à compra de ações e facilitava o pagamento de débitos fiscais.

\footnotetext{
${ }^{71}$ MATTOS FILHO, Ary Oswaldo; PRADO, Viviane Muller. Tentativas de desenvolvimento do mercado acionário brasileiro desde 1964. In: LIMA, Maria Lúcia de Padua (Coord.). Agenda contemporânea: direito e economia: 30 anos de Brasil. São Paulo: Saraiva: 2012. t. 2, p. 194.

${ }^{72}$ Id., loc. cit.

73، A renúncia fiscal (sob o ponto de vista do governo) ou os incentivos fiscais (sob o ponto de vista do contribuinte) eram instrumentos de política econômica do governo bastante conhecidos e utilizados desde 1963, com a Lei n. 4.238/63, para alocar investimentos para o Nordeste (SUDENE).” Id. Ibid., p. 196.
} 
Esta política de estímulo fiscal às aplicações foi responsável pelo aumento de recursos privados no mercado de capitais. Pessoas físicas, que aplicaram suntuosos montantes no mercado acionário, não possuíam verdadeiro interesse em se tornarem investidoras, mas sim em usufruir dos incentivos fiscais oferecidos pelo governo. ${ }^{74}$ Em face disso, viveu-se uma época de excesso de recursos disponíveis em relação aos ativos ofertados, o que levou a níveis altos das cotações das ações e dos seus volumes de negociação.

No ano de 1971, com o início da queda da euforia especulativa, inicia-se a crise do mercado acionário, levando a um período de forte retração no mercado. A constatação é que o mercado ficou grande demais para sua estrutura institucional. Em que pese aos avanços legislativos, algumas omissões também ocorreram. Dentre elas, questões envolvendo a insuficiente proteção ao acionista minoritário, a excessiva assimetria de informação, e a falta de criação de um órgão específico especializado para regular o mercado de capitais. ${ }^{75}$

Consciente das inseguranças e incertezas decorrentes da crise, bem como da necessidade de recuperação do mercado acionário, o governo Médici encomenda dois anteprojetos de lei: ${ }^{76}$ um dispondo sobre as sociedades por ações, e outro criando um órgão especializado encarregado do mercado de capitais. Com isso, foram editadas duas novas legislações. No dia 07 de dezembro de 1976, por meio da publicação da Lei n. ${ }^{\circ}$ 6.385, foi criada a Comissão de Valores Mobiliários (CVM) e, por conseguinte, em 15 de dezembro de 1976, foi publicada a Lei n. ${ }^{\circ}$ 6.404, Lei das Sociedades Anônimas.

Por meio deste primeiro diploma, uma série de atribuições que até então competiam ao $\mathrm{CMN}$ e ao Bacen foram transferidas para a CVM. Fato este que vem se repetindo por meio de alterações na redação original da Lei n. ${ }^{\circ}$ 6.385/1976. Para fins ilustrativos, salientamos a transferência da competência do CMN à CVM para definir os tipos de instituição financeira que poderão exercer atividades no mercado de valores mobiliários ${ }^{77}$;

\footnotetext{
${ }^{74}$ MATTOS FILHO, Ary Oswaldo; PRADO, Viviane Muller. op. cit., p. 205.

${ }^{75}$ ALVARENGA, Maria Isabel de Almeida. Adequação das funções legais da comissão de valores mobiliários à realidade brasileira. Revista de Direito Mercantil, Industrial, Econômico e Financeiro, São Paulo, v. 36, n. 105, p. 146, jan./mar. 1997.

${ }^{76}$ Para narrativa sobre a crise, bem como sobre as discussões que permearam a formulação destes anteprojetos, ver: LAMY FILHO, Alfredo; PEDREIRA, José Luiz Bulhões. A Lei das S.A.: pressupostos, elaboração, aplicação. Rio de Janeiro: Renovar, 1992. p. 136-144.

${ }^{77}$ Art . 15. O sistema de distribuição de valores mobiliários compreende:

$\S 1^{\circ}$-Compete ao Conselho-Monetário Nacional definir:

$\S 1^{\circ}$ Compete à Comissão de Valores Mobiliários definir: (Redação pelo Decreto $n^{\circ} 3.995$, de 31.10.2001)

I - os tipos de instituição financeira que poderão exercer atividades no mercado de valores mobiliários, bem como as espécies de operação que poderão realizar e de serviços que poderão prestar nesse mercado.
} 
a remoção da competência do CMN para conceituar o que seriam situações anormais no mercado $^{78}$; bem como a revogação do comando que estabelecia que as normas gerais editadas pela Comissão deveriam ser previamente propostas e aprovadas pelo CMN. ${ }^{79}$

Verificamos, com isso, que é neste contexto que nasce a CVM, como órgão governamental instituído exclusivamente para regular e desenvolver o mercado de capitais brasileiro, inspirado, conforme vimos, no modelo estadunidense.

\footnotetext{
${ }^{78}$ Art $9^{\circ}$ A Comissão de Valores Mobiliários, observado o disposto no $\S 2^{\circ}$ do art. 15, poderá: (Redação dada pelo Decreto $\mathrm{n}^{\mathrm{o}} 3.995$, de 31.10 .2001 )

$\$ 1^{\circ}$ Com o fim de prevenir ou corrigir situações anormais do mercado, como tais conceituadas pelo Conselho Monetário Nacional, a Comissão poderá:

$\S 1^{\circ}$ Com o fim de prevenir ou corrigir situações anormais do mercado, a Comissão poderá: (Redação pelo Decreto $\mathrm{n}^{\mathrm{o}} 3.995$, de 31.10.2001)

${ }^{79}$ Art . 18. Compete à Comissão de Valores Mobiliários: I propor aө Conselhø Monetário Nacional a aprovação de normas gerais søbre:

Art. 18. Compete à Comissão de Valores Mobiliários: (Redação dada pela Lei $\mathrm{n}^{\circ}$ 10.411, de 26.2.2002)

I - editar normas gerais sobre: (Redação dada pela Lei $\mathrm{n}^{\circ} 10.411$, de 26.2.2002)
} 


\section{2. ÓRgÃo RESPONSÁVEL PELO MERCADO DE CAPITAIS BRASILEIRO: QUAL A NATUREZA JURÍDICA DA COMISSÃO DE VALORES MOBILIÁRIOS?}

Em um mundo cada vez mais globalizado, onde a tecnologia corrente permite a comunicação entre os agentes econômicos em tempo real, não importando mais nacionalidades, idiomas ou localidades no planeta, os governos não dão mais conta de regular as condutas dentro do clássico paradigma de Estado-Nação. Estes, criados e estruturados justamente para disciplinarem fatos sociais no contexto daqueles limites espaço-culturais acima referidos, têm enormes dificuldades para juridicizar satisfatoriamente, i.e., de forma racional, factível e eficiente, as relações humanas em mercados intensamente dinâmicos, onde indústrias, firmas, bens e serviços são criados, modificados e extintos em velocidades impressionantes.

Em segmentos onde a inovação é fortemente incentivada, as revoluções ocorrem e são bem-vindas, ainda que muitas vezes a acolhida calorosa se dê apenas posteriormente a sua ocorrência. Nas ciências, as revoluções científicas inauguram marcos de novos paradigmas $^{80}$ que influenciam a cultura de forma geral e profunda, como ocorreu com as teorias da evolução das espécies na Biologia, da relatividade e da mecânica quântica na Física, para não falar das inovações tecnológicas como o telefone, o rádio, a televisão e a internet.

Nos mercados, a destruição criadora de Schumpeter $^{81}$ não cessa de acontecer e, ainda que muitas vezes traga inquietude a determinados setores econômicos que percebem ser vítimas desses cataclismos revolucionários enquanto eles estão acontecendo, as consequências costumam vir na forma de novos mercados mais dinâmicos e mais geradores de riquezas.

O Direito, no entanto, busca a estabilidade das relações, que é justamente a realidade antônima da inovação constante. Se revoluções são benéficas para a ciência e para o mercado, para os sistemas jurídicos significam a sua ruptura. Nesse diapasão, o princípio da segurança jurídica é o valor que serve de freio às alterações indesejadas das normas, cujo efeito é devastador para a sociedade: inovações incessantes, na seara do

\footnotetext{
${ }^{80}$ Para a concepção de revolução científica e quebra de paradigmas, ver: KUHN, Thomas. A estrutura das revoluções científicas. 5. ed. Trad. Beatriz Vianna Boeira e Nelson Boeira. São Paulo: Perspectiva, 1997.

${ }^{81}$ SCHUMPETER, Joseph A. Capitalism, socialism and democracy. New York: Harper and Row, 1998. p. $82-83$.
} 
Direito, não são bem-vindas. Todavia, cabe também ao Direito regular os mercados dinâmicos e globalizados, o que obriga a própria ciência jurídica a se renovar, de modo a se libertar de certos preconceitos e grilhões dogmáticos. Enquanto a estabilidade é desejada no Direito positivo, não o é na ciência do Direito.

Os fundamentos que os sistemas jurídicos contemporâneos possuem permitem, ainda que em maior ou menor grau de eficácia, que estes lidem com os mercados, incluindo nesses o de capitais, possivelmente o seu segmento mais inovador e dinâmico. Em outras palavras, guardadas as diferenças entre os sistemas particulares, muitos deles têm capacidade regulatória satisfatória, incluindo o brasileiro. Contudo, é necessário que o paradigma da doutrina jurídica pátria, sobretudo a publicista, supere certas concepções que não se mostram mais suficientes para a compreensão do mercado e de como o Direito deve lidar com ele. Como exemplo dessas ideias, a visão clássica de separação dos poderes e da legalidade, como barreiras intransponíveis, que muitas vezes impede até mesmo a análise científica do fenômeno das agências reguladoras, realidade inconteste em nosso ordenamento.

Neste capítulo, limitaremo-nos, todavia, a apresentar o tema, qual seja, das agências reguladoras no direito brasileiro, das diferentes posições doutrinárias a respeito, e da própria Comissão de Valores Mobiliários nesse contexto.

\subsection{Mandamentos constitucionais e a Administração Pública}

Neste tópico trataremos de alguns preceitos constitucionais intimamente ligados à Administração Pública, bem como às agências reguladoras. Utilizamos o termo "mandamento" por tratar-se de normas constitucionais que versam sobre direitos individuais e também sobre a atuação da Administração, e se constituem tanto de princípios como regras, espécies normativas que serão melhor abordadas no capítulo seguinte, mas cuja distinção cumpre aplicar desde já.

\subsubsection{A separação de poderes}

A concepção de separação dos poderes remonta à Grécia e Roma antigas. Neste sentido, esclarece Nuno Piçarra que a "doutrina da separação dos poderes, ao propor-se 
como objectivo fundamental a limitação do poder político, assume-se como tema recorrente do pensamento ocidental, desde a Antiguidade Clássica» ${ }^{~} 82$.

Entretanto, as origens remotas da doutrina da separação dos poderes encontram-se na versão aristotélica da teoria da constituição mista. ${ }^{83}$ Para Aristóteles, a constituição mista compunha a melhor forma de constituição, uma vez que combinava a forma de governo exercida pelos membros da classe rica com a forma de governo exercida pelos membros da classe pobre. ${ }^{84}$

Locke e Rousseau desenvolveram uma doutrina da separação dos poderes que, com certas mudanças, acabou sendo sistematizada e divulgada por Monstesquieu. ${ }^{85}$ No Capítulo VI do Livro XI do seu Do Espírito das Leis, de 1748, Charles de Montesquieu ${ }^{86}$ argumenta:

Quando, na mesma pessoa ou no mesmo corpo de magistratura, o poder legislativo está reunido ao poder executivo, não existe liberdade, pois pode-se temer que o mesmo monarca ou o mesmo senado apenas estabeleçam leis tirânicas para executá-las tiranicamente. Não haverá também liberdade se o poder de julgar não estiver separado do poder legislativo e do executivo. Se estivesse ligado ao poder legislativo, o poder sobre a vida e a liberdade dos cidadãos seria arbitrário, pois o juiz seria legislador. Se estivesse ligado ao poder executivo, o juiz poderia ter a força de um opressor. Tudo estaria perdido se o mesmo homem ou o mesmo corpo dos principais, ou dos nobres, ou do povo, exercesse esses três poderes: o de fazer leis, o de executar as resoluções públicas, e o de julgar os crimes ou as divergências dos indivíduos.

\footnotetext{
${ }^{82}$ PIÇARRA, Nuno. A separação dos poderes como doutrina e princípio constitucional. Coimbra: Coimbra Ed., 1989. p. 31.

83، “...) constituição mista será aquela em que os vários grupos ou classes sociais participam do exercício do poder político, ou aquela em que o exercício da soberania ou o governo, em vez de estar nas mãos de uma única parte constitutiva da sociedade, é comum a todas. Contrapõem-se-lhe, portanto, as constituições puras em que apenas um grupo ou classe social detém o poder político.” PIÇARRA, Nuno. op. cit., p. 33.

${ }^{84}$ ARISTÓTELES. Política. Trad. Mário da Gama Kury. 3. ed. Brasília: Ed. da UnB, 1997. p. 140.

${ }^{85}$ A doutrina acerca da autoria da teoria da separação dos poderes é controvertida: "Há os que consideram, como Marcello Caetano, ser Locke seu autor original. Outros, atribuindo a Montesquieu a autoria da doutrina, consideram Locke mero percussor. Finalmente, há os que não admitem na obra de Locke nenhuma doutrina da separação dos poderes, entendida como exigência de equilíbrio, mas apenas uma distinção das funções estaduais, como Carré de Malberg.". TAVARES, André Ramos. Curso de direito constitucional. 8. ed. São Paulo: Saraiva, 2010. p. 1182.

${ }^{86}$ MONTESQUIEU. O espírito das leis. 2. ed. Trad. Fernando Henrique Cardoso; Leôncio Martins Rodrigues. Brasília: Ed. da UnB, 1995. p. 119.
} 
Foi com a Declaração Francesa dos Direitos do Homem e do Cidadão, de $1789^{87}$, que a separação tripartite de poderes tornou-se um dogma constitucional e, desde então, o princípio da separação dos poderes vem sendo adotado pelo Estado Constitucional. ${ }^{88}$

A doutrina da separação dos poderes busca preconizar que um único órgão não pode acumular poderes para criar a lei, executá-la e dirimir conflitos dela advindos. Foi, portanto, estabelecida a divisão destes poderes, por meio da criação dos poderes Executivo, Legislativo e Judiciário. Ao Legislativo foi concedida a responsabilidade para criação da lei, o Executivo para promover sua execução e o Judiciário para decidir os conflitos de interesses daí oriundos. Com isso, buscou-se de certa forma estabelecer um equilíbrio entre Executivo, Legislativo e Judiciário.

Tal equilíbrio decorre do mecanismo chamado sistema de freio e contrapesos $^{89}$, no qual a autonomia de cada um dos poderes a eles confere a possibilidade de limitar a atuação do outro, a fim de evitar sua supremacia em relação aos demais.

No direito brasileiro não é diferente. A separação dos poderes encontra-se consagrada no artigo $2^{\circ}$ da Constituição Federal, que assim dispõe: "São Poderes da União, independentes e harmônicos entre si, o Legislativo, o Executivo e o Judiciário.” Temos, portanto, três poderes coexistentes, que são independentes ${ }^{90}$ e harmônicos ${ }^{91}$ entre si.

No que tange à ideia de independência, harmonia e equilíbrio entre os poderes Executivo, Legislativo e Judiciário, como forma de fiscalização recíproca de um poder

\footnotetext{
${ }^{87 ،}$ 'Tornou-se, com a Revolução Francesa, um dogma constitucional, a ponto de o art. 16 da Declaração dos Direitos do Homem e do Cidadão de 1789 declarar que não teria constituição a sociedade que não assegurasse a separação de poderes, tal a compreensão de que ela constitui técnica de extrema relevância para a garantia dos Direitos do Homem, como ainda o é." SILVA, José Afonso da. Curso de direito constitucional positivo. 13. ed. São Paulo: Malheiros Ed., 1997. p. 110.

${ }^{88}$ TAVARES, André Ramos. op. cit., p. 1181.

${ }^{89}$ Neste sentido, Monstesquieu já lembrava a necessidade das Câmaras Alta e Baixa: "Num Estado, há sempre pessoas dignificadas pelo nascimento, pelas riquezas ou pelas honrarias; mas se se confundissem com o povo e só tivessem, como os outros, um voto, a liberdade comum seria sua escravidão e não teriam nenhum interesse em defendê-la, porque a maioria das resoluções seriam contra elas. A participação que tomam na legislação deve ser, portanto, proporcional às outras vantagens que têm no Estado, o que acontecerá se formarem um corpo que tenha o direito de sustar as iniciativas do povo, tal como o povo tem o direito de sustar as deles." MONTESQUIEU. op. cit., p. 119.

${ }^{90}$ Ensina-nos José Afonso da Silva que, por independência dos poderes Legislativo, Executivo e Judiciário, podemos compreender: (a) que a investidura e a permanência das pessoas num dos órgãos do governo não dependem da confiança nem da vontade dos outros; (b) que, no exercício das atribuições que lhes sejam próprias, não precisam os titulares consultar os outros nem necessitam de sua autorização; (c) que, na organização dos respectivos serviços, cada um é livre, observadas apenas as disposições constitucionais e legais. SILVA, José Afonso da. op. cit., p. 111.

${ }^{91}$ Por conseguinte, quanto ao sentido de harmonia entre os poderes, salienta o mesmo autor: A harmonia entre os poderes verifica-se primeiramente pelas normas de cortesia no trato recíproco e no respeito às prerrogativas e faculdades a que mutuamente todos têm direito (grifo do autor) SILVA, José Afonso da. op. cit., p. 111.
} 
sobre o outro quanto ao fiel cumprimento dos deveres constitucionais de cada um, podemos destacar alguns exemplos.

Dispõe o artigo 66, $\S 1^{\circ}$, da Constituição Federal ${ }^{92}$, que poderá o Presidente da República vetar, total ou parcialmente, projeto de lei. Esta norma constitucional exemplifica o controle que o Poder Executivo poderá exercer sobre atividade típica do Poder Legislativo.

Já ao tratarmos do artigo 84, inciso XII, da Constituição Federal ${ }^{93}$, nos deparamos com a prerrogativa do Chefe do Poder Executivo de conceder indulto e comutação de penas em determinadas situações. Tal possibilidade retrata uma forma de controle que poderá o Poder Executivo exercer sobre o Judiciário em sua atividade típica jurisdicional.

Por conseguinte, temos o controle do Poder Judiciário exercido em relação ao Legislativo. Em que pese seja atividade típica do Poder Legislativo à edição de diplomas legais, o controle de constitucionalidade destas normas será realizado pelo Poder Judiciário. O Supremo Tribunal Federal, como guardião da Constituição (artigo 102, inciso I, alínea "a""94), exercerá o controle sobre estas normas, podendo, inclusive, declarar-lhes inconstitucionais.

Ao Poder Judiciário também cabe controlar o Poder Executivo. Um exemplo que bem demonstra esta possibilidade está inserido no artigo 52, inciso I e $\S$ único, da Constituição Federal, que dispõe sobre o processo de impeachment. Trata-se de situação na qual, em cooperação entre Poder Legislativo e Poder Judiciário, será exercido o controle em relação ao Poder Executivo. Isto porque prevê a norma constitucional, em seu § único, a participação do Poder Judiciário, por meio do Presidente do Supremo Tribunal Federal.

Por conseguinte, ao tratarmos do controle que poderá ser exercido pelo Poder Legislativo sobre o Executivo, citamos a previsão constitucional contida no artigo 49,

\footnotetext{
${ }^{92}$ Art. 60 .

(...)

$\S 1^{\circ}$ - Se o Presidente da República considerar o projeto, no todo ou em parte, inconstitucional ou contrário ao interesse público, vetá-lo-á total ou parcialmente, no prazo de quinze dias úteis, contados da data do recebimento, e comunicará, dentro de quarenta e oito horas, ao Presidente do Senado Federal os motivos do veto.

${ }^{93}$ Art. 84. Compete privativamente ao Presidente da República:

(...)

XII - conceder indulto e comutar penas, com audiência, se necessário, dos órgãos instituídos em lei;

${ }^{94}$ Art. 102. Compete ao Supremo Tribunal Federal, precipuamente, a guarda da Constituição, cabendo-lhe: I - processar e julgar, originariamente:

a) a ação direta de inconstitucionalidade de lei ou ato normativo federal ou estadual e a ação declaratória de constitucionalidade de lei ou ato normativo federal; (Redação dada pela Emenda Constitucional $\mathrm{n}^{\mathbf{0}} 3$, de 1993).
} 
inciso II, que confere ao Congresso Nacional competência para "autorizar o Presidente da República a declarar guerra, a celebrar a paz, a permitir que forças estrangeiras transitem pelo território nacional ou nele permaneçam temporariamente, ressalvados os casos previstos em lei complementar".

Por fim, no que se refere ao controle do Poder Legislativo em relação ao Poder Judiciário, salientamos a CPI do Judiciário ${ }^{95}$, ocorrida há menos de duas décadas. Trata-se de instrumento de controle do Poder Legislativo que, nesta oportunidade, recaiu sobre o Judiciário, previsto no $\S 3^{\circ}$ do artigo $58^{96}$, da Constituição Federal, que prevê a possibilidade de criação de comissões parlamentares de inquérito com poderes de investigação próprios das autoridades judiciais, além de outros previstos nos regimentos das respectivas Casas.

Percebemos, com isso, não apenas o exercício de controle dos poderes, um sobre o outro, mas também que, em que pese seja à separação dos poderes em Legislativo, Executivo e Judiciário absoluta, não o são suas funções. O que temos, na verdade, é a relativização das funções de cada um destes poderes, bem como da sua independência. ${ }^{97}$

Exemplifica-se: o Executivo não apenas promove a execução de leis, como também edita normas (função legislativa) e decide, por meio de seus órgãos julgadores, lides entre Estado e particular (função judicial, por meio do processo administrativo); o Legislativo, por seu turno, além de produzir leis, também administra o seu próprio orçamento (função executiva) e julga crimes do Presidente da República e dos seus próprios membros (função judicial); por fim, o Judiciário, cuja função principal é decidir conflitos intersubjetivos,

\footnotetext{
${ }^{95}$ A CPI do Judiciário foi criada em março de 1999, durante o governo de Fernando Henrique Cardoso por requerimento do então Senador Antônio Carlos Magalhães. Sua finalidade foi a apuração de denúncias concretas da existência de irregularidades praticadas por integrantes de tribunais superiores, de tribunais regionais e de tribunais de Justiça.

${ }^{96}$ Art. 58

(...)

$\S 3^{\circ}$ - As comissões parlamentares de inquérito, que terão poderes de investigação próprios das autoridades judiciais, além de outros previstos nos regimentos das respectivas Casas, serão criadas pela Câmara dos Deputados e pelo Senado Federal, em conjunto ou separadamente, mediante requerimento de um terço de seus membros, para a apuração de fato determinado e por prazo certo, sendo suas conclusões, se for o caso, encaminhadas ao Ministério Público, para que promova a responsabilidade civil ou criminal dos infratores.

${ }^{97}$ Pois como salienta José Afonso da Silva, "o princípio não configura mais aquela rigidez de outrora. A ampliação das atividades do Estado contemporâneo impôs nova visão da teoria da separação de poderes e novas formas de relacionamento entre os órgãos legislativo e executivo e destes com o judiciário, tanto que atualmente se prefere falar em colaboração de poderes (...).” SILVA, José Afonso da. op. cit., p. 110.
} 
também administra o seu próprio orçamento (função executiva) e cria suas próprias regras internas de funcionamento, por meio de seus regimentos (função legislativa). ${ }^{98}$

Em suma, a separação dos Poderes não implica em limites absolutos de suas funções, sob pena de inviabilizar suas próprias atividades e também negar a própria salvaguarda constitucional. Se, por exemplo, o Executivo fosse impedido de julgar, em nível administrativo, as contendas entre Estado e particular, em nome de uma separação absoluta de poderes, os cidadãos ficariam privados dessa importante esfera do devido processo legal. Da mesma forma, se o Judiciário não pudesse criar seus próprios regimentos, devendo deixá-los a cargo do Legislativo, não apenas haveria uma intromissão indevida de um poder sobre o outro, como também restaria inviabilizado o seu funcionamento interno.

No que se refere à Administração Pública, a separação dos poderes busca delimitar claramente os seus limites normativos, no sentido de vedar sua interferência nos outros poderes, bem como coibir arbitrariedades contra os cidadãos. No que se refere às agências reguladoras, a separação dos poderes é um dos principais argumentos contra a sua possibilidade de inovar no sistema jurídico, conforme veremos em tópico posterior.

\subsubsection{A separação de poderes e o Estado Democrático de Direito}

Ademais, importante também abordar a separação dos poderes em sua relação com a democracia. Estabelece o $\S$ único do artigo $1^{\circ}$, da Constituição Federal, que "Todo o poder emana do povo, que o exerce por meio de representantes eleitos ou diretamente, nos termos desta Constituição.”

Portanto, segundo o preceito constitucional, toda ação do Estado deve ser pautada pela vontade popular. Todavia, importante salientar que a atuação do Estado dirigida exclusivamente pela vontade popular não garante, por si só, soluções democráticas. Ou seja, a atuação estatal pode até representar a vontade da maioria, mas ainda assim não ser uma decisão democrática. Por exemplo, medidas populistas, apoiadas em uma "opinião pública", muitas vezes até manipulada por detentores dos meios de comunicação,

\footnotetext{
${ }^{98}$ Explica Seabra Fagundes que tanto o executivo quanto o judiciário criam leis em sentido material, ou seja, normas gerais que regulam condutas. FAGUNDES, M. Seabra. $O$ controle dos atos administrativos pelo poder judiciário. 3. ed. atual. Rio de Janeiro: Forense, 1957. p. 39.
} 
provavelmente destoariam de um autêntico Estado Democrático de Direito. Tais medidas não seriam, em essência, muito distintas de um linchamento de um criminoso levado a cabo por alguma turba enfurecida.

Em um verdadeiro Estado Democrático de Direito, a prevalência da vontade da maioria em nada deve diferir da prevalência da vontade da minoria. Aliás, a vontade da minoria, neste contexto, deve ser firmemente resguardada, como forma de garantir, sobretudo, seus direitos individuais, estes sim, elementos essenciais de qualquer democracia. Pois como Ayn Rand" ${ }^{99}$ bem coloca: "lembre também que a menor minoria na Terra é o indivíduo. Aqueles que negam os direitos individuais, não podem alegar serem defensores das minorias." Ordens normativas que priorizem supostos direitos do "povo" ou da “coletividade" sem preocupar-se com o indivíduo, acabam não protegendo nem um nem outro.

Nesse item, cumpre salientar que, da mesma forma que a legalidade, a separação dos poderes não guarda relação de identidade ou mesmo de condição necessária para com o Estado Democrático de Direito. Posto de forma mais simples, não é a referida garantia, por si só, que garantirá um regime político pautado pela liberdade e pelos direitos individuais. $^{100}$

O que sustenta um regime político pautado pela liberdade individual é um plexo de valores morais, consubstanciados em princípios jurídicos nucleares de um sistema constitucional, que protejam, primordialmente, os direitos dos indivíduos. Como veremos adiante, tais valores fundamentais têm correlação, de fato, com a separação dos poderes e com a legalidade, mas nem por isso tais cláusulas pétreas constitucionais são universais e logicamente necessárias para alcançar um sistema político e social livre. Outrossim, a separação dos poderes é um meio, método ou técnica para alcançar esse fim, mas nem por isso a única, nem tampouco absoluta, forma - trata-se de regra constitucional, portanto, que visa alcançar o princípio da segurança jurídica e os valores do Estado Democrático de Direito, regime preservador das liberdades.

\footnotetext{
${ }^{99}$ Tradução livre: "Remember also that the smallest minority on earth is the individual. Those who deny individual rights, cannot claim to be defenders of minorities." RAND, Ayn. America's persecuted minority: big business, 1961. Gravação de áudio. Disponível em: <http://www.aynrand.org/site/PageServer?pagename=reg_ar_bigbusiness>. Acesso em: 21 dez. 2011.

${ }^{100}$ Conforme Marçal Justen Filho, “...pode-se afirmar que tripartição de poderes não é um instituto políticojurídico bastante, por si só (quer no passado, como nos dias atuais), para garantir a implantação da democracia ou para o desempenho adequado e satisfatório das funções governamentais." JUSTEN FILHO, Marçal. op. cit., p. 349.
} 


\subsubsection{A legalidade}

A legalidade, no ordenamento jurídico pátrio, integra o rol de direitos individuais e, portanto, é cláusula pétrea constitucional, conforme o artigo $60, \S 4^{0}$, inciso IV, da Carta Magna. ${ }^{101}$ Repetindo preceito de Constituições anteriores, dispõe a Carta de 1988, no inciso II de seu artigo $5^{\circ}$, que "ninguém será obrigado a fazer ou deixar de fazer alguma coisa senão em virtude de lei”. Ademais, a garantia está também radicada no artigo $37^{102}$, que trata da Administração Pública.

A legalidade é uma das mais importantes salvaguardas do Estado democrático de direito. Trata-se de garantia individual de que as regras do jogo são aquelas oriundas de lei, e que somente por meio dela é que estas regras serão alteradas. É a expressão da vontade do povo, por meio de representantes por ele eleitos.

A importância da legalidade justifica-se justamente na concepção de que a criação de quaisquer novos deveres, direitos ou obrigações, serão postos a debate por representantes eleitos pelo voto universal, periódico e secreto, anteriormente à sua introdução no mundo jurídico. ${ }^{103}$ Neste sentido, a legalidade é sobremodo importante, pois serve para apontar a fonte produtora da norma, qual seja, o legislativo.

Como veremos adiante, a legalidade é uma regra constitucional de atendimento objetivamente verificável: se o veículo introdutor de determinada norma no sistema for lei, a legalidade foi cumprida. Se, por outro lado, o comando que implica em direitos ou deveres inovadores no ordenamento for introduzido por veículo não legal (e.g. Decreto), a legalidade não foi atendida. A análise de seu cumprimento dispensa, portanto, maiores discussões acerca de valores e conceitos, ao contrário do que ocorre, por exemplo, ao tratarmos da isonomia e da dignidade da pessoa humana, princípios jurídicos tipicamente vagos e abertos semanticamente.

\footnotetext{
${ }^{101}$ Art. 60.

(...)

$\S 4^{\circ}$ - Não será objeto de deliberação a proposta de emenda tendente a abolir:

(...)

IV - os direitos e garantias individuais.

${ }^{102}$ Enquanto naquela administração é lícito fazer tudo que não for proibido por lei, na Administração Pública só é permitido fazer o que a lei expressamente autoriza.

${ }^{103}$ Neste sentido, José Afonso da Silva, ao tratar da legalidade, assevera: “(...) de sorte que a ideia matriz está em que só o Poder Legislativo pode criar regras que contenham, originariamente, novidade modificativa da ordem jurídico-formal, o que faz coincidir a competência da fonte legislativa com o conteúdo inovativo de suas estatuições, com a consequência de distingui-la da competência regulamentar." (grifo do autor) SILVA, José Afonso da. op. cit., p. 400-401.
} 


\subsubsection{A segurança jurídica}

Segurança jurídica significa estabilidade do sistema jurídico que, por seu turno, possibilita a estabilidade da ordem social. A ordem jurídica gera uma constante tensão entre sua função calibradora do sistema social, considerando que o Direito reprime condutas intersubjetivas indesejadas, e sua função promotora de valores e fins almejados pelo legislador, o que muitas vezes requer mudanças e, portanto, instabilidade.

Todavia, a segurança jurídica, sobreprincípio implícito na Constituição ${ }^{104}$, permite conhecimento prévio das regras do jogo pelos cidadãos, que se tornam capazes então de calcular as consequências jurídicas de suas ações. ${ }^{105}$ Tal conhecimento prévio possibilita um ambiente de paz social capaz de gerar desenvolvimento econômico e social.

Portanto, não se trata de princípio expressamente aludido em dispositivo específico da Constituição Federal, mas sim de preceito que permeia o sistema constitucional como um todo. Conforme leciona Celso Antônio Bandeira de Mello: ${ }^{106}$

(...) o princípio da segurança jurídica, o qual, se acaso não é o maior de todos os princípios gerais de direito, como acreditamos que efetivamente o seja, por certo é um dos maiores dentre eles. Por força do sobredito princípio cuida-se de evitar alterações surpreendentes que instabilizem a situação dos administrados e de minorar os efeitos traumáticos que resultem de novas disposições jurídicas que alcançariam situações em curso. A prescrição, o direito adquirido, são exemplos de institutos prestigiadores da segurança jurídica. (grifo do autor).

Ao concluir a ideia acima exposta, o autor refere a prescrição e o direito adquirido como exemplos de institutos que prestigiam o princípio da segurança jurídica. Tratam-se, portanto, da prescrição e o direito adquirido de regras objetivamente observáveis, cuja finalidade é assegurar que o valor segurança jurídica (este como um fím, e não como um meio) seja alcançado.

Sendo o sobreprincípio da segurança jurídica aquele valor que reconhece aos indivíduos a prerrogativa de previsibilidade das regras do jogo, necessário se faz sejam desenvolvidos meios que instrumentalizem sua aplicação. É neste contexto que se inserem as regras jurídicas, cunhadas de objetividade e clareza que, como os exemplos supracitados

\footnotetext{
${ }^{104}$ CARVALHO, Paulo de Barros. Direito tributário, linguagem e método. São Paulo: Noeses, 2008. p. 263.

105“Dita previsibilidade é, portanto, o que condiciona a ação humana.” MEIRELLES, Hely Lopes. Direito administrativo brasileiro. 23. ed. São Paulo, Malheiros Ed., 1998. p. 113-114.

${ }^{106}$ Id. Ibid., p. 77.
} 
da prescrição e direito adquirido, viabilizam aos cidadãos a fiel observância do princípio da segurança jurídica.

\subsubsection{O devido processo legal}

O princípio do devido processo legal constitui, juntamente com a segurança jurídica, um dos fundamentos do Estado Democrático de Direito e uma das clássicas salvaguardas contra o arbítrio do Estado.

Com origem conceitual na Magna Carta inglesa, de $1215^{107}$, e posterior e literalmente veiculada em lei inglesa de 1315 e na Bill of Rights ${ }^{108}$, declaração de direitos individuais que foi emendada à Constituição dos Estados Unidos da América, em 1791, a cláusula do devido processo legal passou a ser o marco que identifica a qualificação de "democrático" a todo sistema jurídico particular. Em nosso sistema, o princípio está expresso no artigo $5^{\circ}$, inciso LIV, da Constituição Federal de 1988: "ninguém será privado da liberdade ou de seus bens sem o devido processo legal".

Em sua manifestação "substantiva", o devido processo legal significa o controle de constitucionalidade das leis, tanto difuso quanto concentrado. ${ }^{109}$ Em sua versão "adjetiva", significa a possibilidade de contraditório no processo, administrativo ou judicial.

O devido processo legal, enquanto princípio, torna-se efetivo à medida que determinadas regras objetivas sejam cumpridas. No que se refere ao devido processo legal adjetivo, as regras constitucionais que permitem alcançar o referido princípio são disposições de fácil verificação quanto ao seu atendimento, como, por exemplo: a vedação ao tribunal de exceção (artigo $5^{\circ}$, inciso XXXVII); o contraditório e ampla defesa (artigo $5^{\circ}$, inciso $\mathrm{LV}$ ); e o direito à identificação da autoridade que está lhe prendendo ou interrogando (artigo $5^{\circ}$, inciso LXIV).

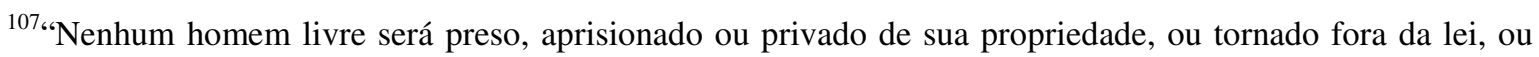
exilado, ou de maneira alguma destruído, nem agiremos contra ele ou mandaremos alguém contra ele, a não ser por julgamento legal dos seus pares, ou pela lei da terra."

108 "No person [...] shall be compelled in any criminal case to be a witness against himself, nor be deprived of life, liberty, or property, without due process of law."

${ }^{109} \mathrm{O}$ controle difuso tem origem com o caso Marbury vs. Madison, julgado pela Suprema Corte estadunidense, em 1803. O controle concentrado, por sua vez, foi criado por Hans Kelsen, para o sistema constitucional austríaco do início do século vinte. KELSEN, Hans. Jurisdição constitucional. 2. ed. Trad. Alexandre Krug. São Paulo: Martins Fontes, 2007. p. VIII.
} 
Interessante perceber que, nos Estados Unidos da América, país de tradição e cultura fortemente arraigadas aos direitos individuais, não há sequer menção a qualquer princípio ou regra da legalidade, conforme tal preceito é compreendido em nosso sistema. O que realmente importa, enquanto garantia da vida, liberdade e propriedade é a possibilidade de o indivíduo se insurgir contra o sistema normativo, por intermédio de remédios jurídicos previstos no próprio sistema, ou seja, o devido processo legal. O nosso sistema, por sua vez, de influência ibérica e sobremaneira formalista, alça a legalidade ao mesmo patamar do devido processo legal, enquanto direitos fundamentais do indivíduo.

Em países como o nosso, com uma triste experiência histórica com regimes autoritários, o devido processo legal, efetivo e eficiente, mostra-se uma das principais (senão a principal) garantias contra arbitrariedades da Administração Pública, abrangidas nela as agências reguladoras.

\subsubsection{A eficiência}

Em termos econômicos, eficiência está diretamente relacionada com os meios empregados para realizar determinada tarefa. Será mais eficiente, portanto, aquele que desempenhar dada função utilizando menos recursos que outro indivíduo, ou, ainda, que obtiver melhor resultado empregando os mesmos recursos. Em outras palavras: ser eficiente é fazer o mesmo utilizando menos recurso, ou mais com o mesmo recurso. Mankiw ${ }^{110}$ define eficiência como "a propriedade que a sociedade tem de obter o máximo possível a partir de seus recursos escassos".

Transpondo esta definição para a esfera jurídica, podemos identificar que uma lei será mais eficiente que outra quando lograr êxito em obter os mesmos resultados com o menor custo possível. Ao falarmos em custo, não nos referimos exclusivamente ao custo financeiro. Os custos da lei podem estar relacionados, por exemplo, às obrigações acessórias que deverão ser observadas por seu destinatário ao cumprir o comando legal (custo de conformidade ${ }^{111}$ ); à renúncia por outra solução legal alternativa (custo de

\footnotetext{
${ }^{110}$ MANKIW, N. Gregory. op. cit., p. 5.

${ }^{111}$ Custo de oportunidade é o custo decorrente do dispêndio de tempo ou dinheiro para se estar de acordo com as exigências do governo, tais como a tributação e regulação. BANNOCK, Graham; BAXTER, R. E.; DAVIS, Evan. The penguin dictionary of economics. 7. ed. Londres: Penguin Books, 2003. p. 66.
} 
oportunidade $^{112}$ ); ou ao grau de intervenção estatal gerado pela norma no mercado (custo de transação $\left.{ }^{113}\right)$.

A referência à eficiência na Constituição Federal, em contrapartida, encontra-se relacionada com a Administração Pública. Por meio da Emenda Constitucional n ${ }^{0} 19$, de 1998, foi inserido o princípio da eficiência entre os princípios constitucionais da Administração Pública, previstos no caput do artigo 37. ${ }^{114}$ Ademais, também a Lei n. ${ }^{\circ}$ 9.784/1999, que regula o processo administrativo no âmbito da Administração Federal, fez referência ao princípio da eficiência no caput do artigo $2^{\circ}$.

Hely Lopes Meirelles ${ }^{115}$, ao tratar do tema, classifica eficiência como um dos deveres da Administração Pública, definindo-o como o dever:

que se impõe a todo agente público de realizar suas atribuições com presteza, perfeição e rendimento funcional. É o mais moderno princípio da função administrativa, que já não se contenta em ser desempenhada apenas com legalidade, exigindo resultados positivos para o serviço público e satisfatório atendimento das necessidades da comunidade e de seus membros.

Trata-se, pois, em termos constitucionais, de preceito direcionado ao agente público no desempenho de suas funções. Suas tarefas não deverão ser apenas cumpridas, mas cumpridas da maneira mais correta e com o menor desperdício possível, de forma a otimizar seu desempenho. Relaciona-se diretamente às regras de boa administração, inclusive das agências reguladoras.

\subsubsection{A especialidade}

A especialidade, quando tratada no contexto da Administração Pública, refere-se à possibilidade de se criar entes notadamente capacitados para o desempenho de determinada tarefa. Trata-se, portanto, do reconhecimento do Estado de que certos serviços serão melhor prestados por entidades dotadas de conhecimento específico sobre a matéria.

\footnotetext{
${ }^{112}$ É aquele custo que incorre o indivíduo por deixar de escolher a segunda melhor alternativa. Em outras palavras, o custo de algo inclui o custo daquilo que é preciso sacrificar para obtê-lo. WESSELS, Walter J. Economics. 4. ed. New York: Barrons's, 2006. p. 3.

${ }^{113}$ É o custo incorrido pelas partes "no processo de efetivação de uma negociação." MANKIW, N. Gregory. op. cit., p. 211.

${ }^{114}$ Art. 37. A administração pública direta e indireta de qualquer dos Poderes da União, dos Estados, do Distrito Federal e dos Municípios obedecerá aos princípios de legalidade, impessoalidade, moralidade, publicidade e eficiência (...).

${ }^{115}$ MEIRELLES, Hely Lopes. op. cit., p. 93.
} 
Para isso, o poder público cria uma pessoa jurídica e a ela atribui a titularidade e a execução de determinado serviço público, e o meio utilizado pelo Estado para isso é a descentralização. Este é o motivo de dizer-se que a especialidade está intimamente relacionada à ideia de descentralização administrativa. Ou seja, é o Estado criando entidade especializada em determinada função, por meio da descentralização da prestação de serviços públicos.

Esta criação se dará por meio de lei e, segundo os ensinamentos de Maria Sylvia Zanella Di Pietro ${ }^{116}$, "a lei que cria a entidade estabelece com precisão as finalidades que lhe incumbe atender, de tal modo que não cabe aos seus administradores afastar-se dos objetivos definidos na lei; isto precisamente pelo fato de não terem a livre disponibilidade dos interesses públicos”. Portanto, a lei instituidora da entidade veiculará com exatidão sua finalidade e seus limites, que não poderão ser desrespeitados no desempenho de suas atividades.

Quanto à entidade que será instituída para desempenhar estas atividades que requerem conhecimento especial, sua criação se dá comumente por meio da figura da autarquia. ${ }^{117}$ São elas as pessoas jurídicas públicas administrativas criadas pelo Estado para auxiliá-lo, conforme a seguir veremos.

\subsection{Autarquias especiais: as agências "reguladoras"}

A expressão "agência reguladora" é relativamente nova em nosso sistema jurídico, e denota uma espécie de importação de instituto jurídico, mais propriamente as "agencies" estadunidenses. Não obstante algumas das agências pátrias levarem tal substantivo em seus nomes, o fato é que juridicamente o instituto a que se subsomem é o das autarquias.

Sendo assim, nos cabe, ainda que resumidamente, abordar certos aspectos da figura da autarquia, bem como das características que a tornam sob regime especial.

\footnotetext{
${ }^{116}$ DI PIETRO, Maria Sylvia Zanella. Direito administrativo. 20. ed. São Paulo: Atlas, 2007. p. 63.

117 "No Brasil, essa criação somente pode dar-se por meio de lei e corresponde, basicamente, à figura da autarquia (...)”. (grifos do autor) DI PIETRO, Maria Sylvia Zanella. op. cit., p. 382.
} 


\subsubsection{As autarquias sob regime especial}

No direito brasileiro, a primeira definição de autarquia foi dada pelo artigo $2^{\circ}$ do Decreto-Lei n. ${ }^{\circ}$ 6.016, de 1943, que a classificava como “o serviço estatal descentralizado, com personalidade de direito público, explícita ou implicitamente reconhecida por lei". ${ }^{118}$ Algumas décadas depois, em 25 de fevereiro de 1967, o Decreto-Lei n. ${ }^{\circ} 200$ trouxe, em seu artigo $5^{\circ}$, inciso I, a definição legal de autarquia que até hoje perdura.

Dispõe o referido dispositivo que autarquia é "o serviço autônomo, criado por lei, com personalidade jurídica, patrimônio e receita próprios, para executar atividades típicas da Administração Pública, que requeiram, para seu melhor funcionamento, gestão administrativa e financeira descentralizada."

Ao compararmos ambas as definições de autarquia, percebemos que a legislação atual pecou ao deixar de lado qualquer referência ao relevante traço da natureza pública de sua personalidade, como fazia o diploma de 1943. Entretanto, não obstante a ausência de qualquer menção à sua personalidade de direito público, tanto a doutrina quanto a jurisprudência jamais deixaram de "reconhecer o caráter de entidade autárquica às pessoas meramente administrativas revestidas de personalidade de Direito Público."119

Em que pese às discrepâncias havidas entre estas definições, certo é que a exigência de criação por lei esteve sempre prevista em ambos os diplomas e, por meio da Emenda Constitucional n. ${ }^{\circ}$ 19, de 1998, passou também a constar no inciso XIX do artigo 37, da Constituição Federal. ${ }^{120}$

São as autarquias ${ }^{121}$, portanto, nas palavras de Celso Antônio Bandeira de Mello ${ }^{122}$, pessoas jurídicas que:

\footnotetext{
${ }^{118}$ Em que pese esta seja a primeira definição legal de autarquia, Maria Sylvia Zanella Di Pietro alerta que, segundo alguns, a Caixa Econômica Federal teria sido a primeira autarquia nacional. Teria sido instituída pelo Governo Imperial, em 1861. DI PIETRO, Maria Sylvia Zanella. op. cit., p. 398.

${ }^{119}$ MELLO, Celso Antônio Bandeira de. Curso de direito administrativo. 16. ed. São Paulo: Malheiros Ed., 2003. p. 148.

${ }^{120}$ Art. 37.

(...)

XIX - somente por lei específica poderá ser criada autarquia e autorizada a instituição de empresa pública, de sociedade de economia mista e de fundação, cabendo à lei complementar, neste último caso, definir as áreas de sua atuação; (Redação dada pela Emenda Constitucional n ${ }^{\circ} 19$, de 1998).

${ }^{121}$ Já Maria Sylvia Zanella Di Pietro as define como: “(...)a pessoa jurídica de direito público, criada por lei, com capacidade de autoadministração, para o desempenho de serviço público descentralizado, mediante controle administrativo exercido nos limites da lei." (grifo do autor) DI PIETRO, Maria Sylvia Zanella. op. cit., p. 400.

${ }^{122}$ MELLO, Celso Antônio Bandeira de. op. cit., p. 148.
} 
gozam de liberdade administrativa nos limites da lei que as criou; não são subordinadas a órgão algum do Estado, mas apenas controladas, como ao diante melhor se esclarece. Constituindo-se em centros subjetivados de direitos e obrigações distintos do Estado, seus assuntos são assuntos próprios; seus negócios, negócios próprios; seus recursos, não importa se oriundos de trespasse estatal ou hauridos como produto da atividade que lhes seja afeta, configuram recursos e patrimônio próprios, de tal sorte que desfrutam de "autonomia" financeira, tanto como administrativa; ou seja, suas gestões administrativa e financeira necessariamente são de suas próprias alçadas - logo, descentralizadas. (grifos do autor).

Indo além, Hely Lopes Meirelles ${ }^{123}$ aponta, conforme a seguir colacionado, que as autarquias não agem por delegação, mas sim por direito próprio:

A autarquia não age por delegação; age por direito próprio e com autoridade pública, na medida do jus imperii que lhe foi outorgado pela lei que a criou. Como pessoa jurídica de Direito Público interno, a autarquia traz ínsita, para a consecução de seus fins, uma parcela do poder estatal que lhe deu vida. Sendo um ente autônomo, não há subordinação hierárquica da autarquia para com a entidade estatal a que pertence, porque, se isto ocorresse, anularia seu caráter autárquico. Há mera vinculação à entidade-matriz, que, por isso, passa a exercer um controle legal, expresso no poder de correção finalística do serviço autárquico. (grifos do autor).

Concluímos, com isso, que as autarquias possuem liberdade para agir dentro dos limites estabelecidos pelas leis que as criaram.

Sendo, portanto, a autarquia uma pessoa jurídica de direito público, vinculada à autoridade estatal a que pertence sem, contudo, estar a ela subordinada, e cuja liberdade encontra-se adstrita à lei que a criou, como diferenciá-la daquela sob regime especial? Ou melhor: quais são os traços ou características que diferenciam uma autarquia geral daquelas sob regime especial?

\section{Conforme noticia Celso Antônio Bandeira de Mello: ${ }^{124}$}

Nos últimos anos, como fruto da mal-tramada "Reforma Administrativa", surgiram algumas autarquias qualificadas como "autarquias sob regime especial". São elas as denominadas "agências reguladoras". Não havendo lei alguma que defina genericamente o que se deva entender por tal regime, cumpre investigar, em cada caso, o que se pretende com isso. A ideia subjacente continua a ser a de que desfrutariam de uma liberdade maior do que as demais autarquias. Ou seja: esta especialidade do regime só pode ser detectada verificando-se o que há de peculiar no regime das "agências reguladoras" em confronto com a generalidade das autarquias.

\footnotetext{
${ }^{123}$ MEIRELLES, Hely Lopes. op. cit., p. 298.

${ }^{124}$ MELLO, Celso Antônio Bandeira de. op. cit., p. 156.
} 
É, portanto, a autarquia sob regime especial, o instituto jurídico que dá forma à agência reguladora.

Quanto ao "regime especial", conforme acima referido, a verdade é que sua definição não encontra-se inserida na Constituição Federal, nem tampouco em uma lei geral que defina e regule essas entidades. Trata-se de categorização estipulada em cada uma das leis criadoras destas autarquias. ${ }^{125}$ Destarte, a caracterização e notas definitórias da autarquia "sob regime especial" ficam, ao menos dentro de limites gerais da ordem jurídica, ao bel-prazer do legislador que cria a autarquia específica.

Embora não haja a definição expressa, é possível identificar alguns traços específicos das autarquias criadas sob este regime especial. Neste sentido, assevera Maria Sylvia Zanella Di Pietro que: ${ }^{126}$

o regime especial vem definido nas respectivas leis instituidoras, dizendo respeito, em regra, à maior autonomia em relação à Administração Direta; à estabilidade de seus dirigentes, garantida pelo exercício de mandato fixo, que eles somente podem perder nas hipóteses expressamente previstas, afastada a possibilidade de exoneração ad nutum; ao caráter final das suas decisões, que não são passíveis de apreciação por outros órgãos ou entidades da Administração Pública. (grifo do autor).

Cotejando a definição de autarquia trazida pelo artigo $5^{\circ}$, inciso I, do Decreto-Lei n. ${ }^{\circ}$ 200/1967, em relação aos elementos apontados por Maria Sylvia Zanella Di Pietro como caracterizadores da especialidade do regime das agências reguladoras, percebemos que as peculiaridades marcantes deste segundo regime estão ligadas à intensidade da autonomia em relação à Administração Pública, manifestada por critérios como a investidura de mandato fixo e estável aos dirigentes, e o caráter final de suas decisões.

\footnotetext{
${ }^{125} \mathrm{O}$ que há, portanto, é uma definição denotativa (ou ostensiva) destas autarquias, ou seja, uma definição imprecisa, oriunda da observação de exemplos destas características em cada uma das leis instituidoras. Em contrapartida, teríamos a definição conotativa, isto é, o estabelecimento de traços definitórios por meio de previsão legal sobre o que seria autarquia sob regime especial. Para mais, ver: CARVALHO, Paulo de Barros. Direito tributário: fundamentos jurídicos da incidência. 4. ed. São Paulo: Saraiva, 2006. p. 101.

${ }^{126}$ DI PIETRO, Maria Sylvia Zanella. op. cit., p. 436.
} 


\subsubsection{As agências reguladoras}

Pode-se dizer que a concepção de agência surgiu no Brasil por uma necessidade do Estado frente ao desenvolvimento e crescimento da complexidade das relações sociais. Foi a opção organizacional por ele adotada para dar conta das suas funções, frente ao aumento de suas atribuições. ${ }^{127}$ Para isso, teve o Brasil como inspiração o modelo estadunidense das agencies.

Nos Estados Unidos ${ }^{128}$, as agências reguladoras surgiram dentro de um contexto típico de um sistema de Common Law, mais preocupado com aspectos pragmáticos do Direito do que propriamente concepções doutrinárias arraigadas. Foi o direito estadunidense, em decorrência da globalização, que serviu de modelo para o fenômeno da proliferação de agências. ${ }^{129}$

Discussões envolvendo a necessidade de criação destas agências se iniciaram por volta dos anos 1860, em decorrência do extraordinário progresso das atividades ferroviárias, cujo setor concentrava mais capital do que qualquer outro setor industrial estadunidense. Por tratar-se de função essencial na sociedade, as ferrovias passaram a sobrepor-se aos demais setores da economia. Com isso, instaurou-se uma insatisfação popular contra as empresas de transporte ferroviário, que procuravam obter o máximo de lucro nas tarifas que livremente estipulavam. ${ }^{130}$

Criou-se, então, em 1887, a primeira agência formalmente instituída nos Estados Unidos. A Interstate Commerce Comission (ICC) foi instituída a fim de regular os serviços interestaduais de transporte ferroviário.

Entretanto, foi após a crise de 1929, por meio do New Deal ${ }^{131}$, que substitui-se uma política econômica inspirada no liberalismo por uma política ancorada no ativismo estatal.

\footnotetext{
${ }^{127}$ JUSTEN FILHO, Marçal. op. cit., p. 353.

${ }^{128}$ Os Estados Unidos, conforme aponta Odete Medauar, sofreram influência inglesa ao criarem suas agencies: "Na Inglaterra, a partir de 1834, floresceram entes autônomos, criados pelo Parlamento para concretizar medidas previstas em lei e para decidir controvérsias resultantes desses textos; a cada lei que disciplinasse um assunto de relevo, criava-se um ente para aplicar a lei. Os Estados Unidos sofreram influência inglesa e desde 1887, com a criação da "Interstate Commerce Commission", tem início a proliferação de agencies para a regulação de atividades, imposição de deveres na matéria e aplicação de sanções (...)." MEDAUAR, Odete. Direito administrativo moderno. 8. ed. São Paulo: Ed. Revista dos Tribunais, 2004. p. 85.

${ }^{129}$ DI PIETRO, Maria Sylvia Zanella. Parcerias na administração pública: concessão, permissão, franquia, terceirização e outras formas. 4. ed. São Paulo: Atlas, 2002. p. 143.

${ }^{130}$ JUSTEN FILHO, Marçal. op. cit., p. 73-74.

${ }^{131}$ O New Deal, encomendado pelo então Presidente Franklin D. Roosevelt, foi uma série de programas econômicos implantados nos Estados Unidos entre os anos de 1933 e 1936. Esta legislação aparece, em um primeiro momento, "num clima de emergency e recovery, mais do que propriamente uma reforma. (...) A
} 
Com isso, as agências reguladoras ganharam destaque ${ }^{132}$, atuando nos mais diversos setores da economia estadunidense. Durante as décadas de 1930 e 1940, foram criadas diversas agências, como forma de pregar maior interferência do poder estatal no âmbito econômico.

Em 1946 foi editada a Federal Administrative Procedure Act, uma lei de procedimento administrativo que impôs uma série de limites à atividade das agencies, trazendo consigo regras referentes à produção normativa das agências, bem como regras uniformizando o processo de tomada de decisão nos casos concretos, como condição de validade para as deliberações por elas tomadas.

A partir de 1985, iniciou-se um processo para se firmar um modelo regulatório independente, com controles externos adequados para garantir esta independência. ${ }^{133}$

Afora estas discussões, outras discussões de cunho jurídico permearam a criação das agencies. A exemplo de controvérsias surgidas no direito brasileiro envolvendo a doutrina da separação dos poderes, conforme a seguir veremos, o mesmo se deu nos Estados Unidos.

A Constituição dos Estados Unidos de 1787, que já trazia em seu bojo a sistemática da separação dos poderes, não previa expressamente a figura da agência. Por serem as agências entes que acumulam poderes de natureza distinta, a constitucionalidade desse modelo foi questionada. Controvérsias envolvendo a separação dos poderes estiveram subjacentes em todas as discussões acerca da figura das agências nos Estados Unidos. ${ }^{134}$

Nas contendas ocorridas nos anos que seguiram à Independência dos Estados Unidos, a Suprema Corte adotou o enfoque assumido por Madison, quando das

obra legislativa do New Deal, toda ela, timbra assim em afirmar o seu caráter emergencial." (grifos do autor). Teve como inspiração as ideias de John Maynard Keynes, para quem o Estado deveria ampliar suas funções, e intervir na economia de forma decisiva. LEÃES, L. G. Paes de Barros. Mercado de capitais \& insider trading, cit., p. 13-15.

${ }^{132}$ Todavia, o crescimento do direito das agências deu-se principalmente a partir da década de 1930, incentivado pela política do New Deal do então presidente, Franklin D. Roosevelt. DI PIETRO, Maria Sylvia Zanella. Parcerias na administração pública: concessão, permissão, franquia, terceirização e outras formas, cit., p. 145.

${ }^{133}$ MENDES, Conrado Hübner. Reforma do Estado e agências reguladoras: estabelecendo os parâmetros de discussão. In: SUNDFELD, Carlos Ari (Coord.). Direito administrativo econômico. São Paulo: Malheiros Ed., 2000. p. 120-121.

${ }^{134}$ Prossegue Marçal Justen Filho, ao tratar das discussões estadunidenses envolvendo a separação de poderes, apontando que: “(...) uma das mais conhecidas críticas disparadas contra as agências, constante do relatório de 1937 da Comissão Brownlow, no sentido de que as agências independentes "são em realidade governos independentes em miniatura, estabelecidos para lidar com a problemática das ferrovias, a problemática dos bancos ou a problemática dos rádios. Elas se constituem em um "quarto poder" do Estado, destituído de comando (headless 'fourth branch' of the Government), um desorganizado conjunto de representantes (agencies) irresponsáveis e poderes descoordenados. Elas efetivamente violentam a teoria básica da Constituição Americana, de que deve haver três e apenas três poderes". JUSTEN FILHO, Marçal. op. cit., p. 84-85. 
manifestações acerca das agências e sua relação com a separação dos poderes. Madison destacou a ausência de um modelo preciso de tripartição de poderes, apontando não haver distinção absoluta de competências entre os diferentes órgãos governativos. E assim Marçal Justen Filho ${ }^{135}$ conclui:

Daí Madison extraiu a ponderação de que a separação de poderes não implicava a impossibilidade de relações de controle ou dependência entre os diferentes órgãos estatais. A única conclusão que se poderia adotar a propósito do tema, por isso, seria a de que "onde a totalidade da competência de um poder é exercitada pelas mesmas mãos que possuem a totalidade de competência de outro poder, os princípios fundamentais de uma constituição livre são subvertidos". (...) Madison insistia na inviabilidade de separação absoluta de funções, sendo perfeitamente cabível que parcelas da competência própria de um poder fossem atribuídas a outro.

Ao longo desses debates, tanto doutrinários quanto jurisprudenciais, o contorno das agências foi sendo desenhado. Discussões acerca do controle judicial sobre as decisões tomadas pelas agencies, ao longo do tempo, variaram de posição, conforme aponta Marçal Justen Filho: ${ }^{136}$

Ao longo do tempo, a relação entre o Judiciário e as agências evolui pendularmente. Nos períodos anteriores ao New Deal, havia posição muito mais rigorosa acerca da extensão da fiscalização. Após 1930 e até o início da década de 60, a jurisprudência foi bastante condescendente com a atuação das agências. Ao longo dos anos 60 e 70, algumas Cortes passaram a propugnar a necessidade de controle judicial sobre a atividade das agências, inclusive no tocante à revisão do mérito das suas decisões. Após 1970, a Corte Suprema passou a adotar soluções cada vez mais rígidas, reconhecendo a impossibilidade de revisão judicial acerca da atuação regulatória das agências. Essa situação não foi alterada nem mesmo em face das iniciativas produzidas pelo Governo Reagan de restringir a autonomia das agências.

Percebemos, assim, que não apenas no Brasil ocorreram (e ainda ocorrem) discussões e entraves acerca da criação das agências reguladoras. Não obstante estarmos cientes das diferenças intrínsecas ${ }^{137}$ do sistema jurídico dos Estados Unidos em relação ao

\footnotetext{
${ }^{135}$ JUSTEN FILHO, Marçal. op. cit., p. 86.

${ }^{136}$ Id. Ibid., p. 107-108.

${ }^{137}$ Diferenças estas oriundas da natureza dos sistemas, Common Law lá e Civil Law aqui. Este de caráter codificado, sistematizado e dedutivo/subsuntivo, enquanto aquele muito mais indutivo, partindo dos casos concretos para a formulação de standards e precedentes. O sistema brasileiro, altamente influenciado pelo direito continental-europeu busca a ideia de sistema, de ordem científica, e dá primazia ao raciocínio dedutivo, das normas aos fatos. O direito consuetudinário, mais pragmático, prioriza a análise do caso, percorrendo o caminho inverso, dos fatos às normas.
} 
brasileiro, importante ressaltar que tanto lá, fonte inspiradora das agências reguladoras brasileiras, quanto cá, foram enfrentadas discussões envolvendo a doutrina da separação dos poderes.

Quanto à denominação "agência”, nos Estados Unidos, onde tem sentido mais amplo que no Brasil, é utilizado para denominar qualquer autoridade do Governo, "esteja ou não sujeita ao controle de outra agência, com exclusão do Congresso e dos Tribunais", conforme o que expressamente determina o já referido Administrative Procedure Act (Lei de Procedimento Administrativo), de 1946. ${ }^{138}$

Já no que tange à classificação das agências estadunidenses, podemos agrupá-las basicamente sob dois critérios: (a) em relação à natureza de seus poderes; e (b) quanto a sua independência frente ao Poder Executivo.

Quanto aos poderes que as agências possuem, podemos identificar a existência de agências reguladoras (regulatory agencies) e de agências não reguladoras (non regulatory agencies). ${ }^{139}$ Já quanto a sua independência, há as agências executivas (executive agencies) e as agências independentes (independent regulatory agencies or commissions). ${ }^{140}$

As agências reguladoras, ou regulatory agencies, são aquelas que possuem poderes normativos delegados pelo Congresso, para estabelecer regras para os setores econômicos e privados, afetando os direitos e liberdades dos cidadãos. Ademais, possuem competência para dirimir conflitos intersubjetivos. ${ }^{141}$

Já as non regulatory agencies, aquelas que não regulam, suas atividades são voltadas ao reconhecimento de benefícios. Prestam, portanto, serviços de assistência social aos indivíduos, bem como se envolvem com questões referentes à proteção de trabalhadores e pagamento de pensões. ${ }^{142}$

No tocante ao segundo critério, são as agências executivas (executive agencies) aquelas cujos dirigentes podem ser destituídos de seus cargos pelo Chefe do Poder

\footnotetext{
${ }^{138}$ DI PIETRO, Maria Sylvia Zanella. Direito administrativo, cit., p. 430.

${ }^{139}$ Entretanto, "esta distinção acabou sendo superada na jurisprudência, que percebeu, na atividade "não regulatória" aspectos de verdadeira regulamentação, o que fez submeter todas as agências ao due process of law.” FERRAZ JUNIOR, Tercio Sampaio. Como regular agências reguladoras? Revista Eletrônica de Direito Administrativo Econômico (REDAE). Salvador, Instituto Brasileiro de Direito Público, n. 17, fev./abr. 2009. Disponível em: <<http://www.direitodoestado.com.br/redae.asp>. Acesso em: 18 dez. 2011. ${ }^{140}$ MORAES, Alexandre de. Agências reguladoras. Revista dos Tribunais, São Paulo, ano 90, v. 791, p. 746, set. 2001.

${ }^{141}$ CUÉLLAR, Leila. As agências reguladoras e seu poder normativo. São Paulo: Dialética, 2001. p. 68-74.

${ }^{142}$ Id., loc. cit.
} 
Executivo, sem a necessidade de aprovação do ato por parte do Congresso. ${ }^{143}$

E, por fim, as agências independentes (independent regulatory agencies or commissions). São estas últimas dotadas de autonomia estrutural em relação ao Poder Executivo, visto que seus dirigentes são protegidos por uma maior estabilidade. A perda de cargo somente será admissível se concorrerem causas previstas expressamente em lei. ${ }^{144}$

No Brasil, o surgimento das agências reguladoras deu-se juntamente com as privatizações da década de $1990 .{ }^{145}$ O Estado brasileiro, que se encontrava inflado ${ }^{146}$, busca desenvolver a iniciativa privada. A exemplo dos Estados Unidos, percebe a necessidade de criação das agências reguladoras, para assegurar o "poder de intervenção nos mais diversos setores em que se faz necessária a presença reguladora e disciplinadora do Estado" $" 147$.

Com isso, as agências reguladoras foram introduzidas no ordenamento jurídico brasileiro, inicialmente, com a finalidade de desempenhar serviços públicos relacionados a telecomunicações e petróleo. ${ }^{148} \mathrm{O}$ inciso XI do artigo 21, da Constituição Federal ${ }^{149}$ dispõe que cabe à União “explorar, diretamente ou mediante autorização, concessão ou permissão,

\footnotetext{
${ }^{143}$ DI PIETRO, Maria Sylvia Zanella. Direito administrativo, cit., p. 431.

${ }^{144}$ Id., loc. cit.
}

${ }^{145}$ BINENBOJM, Gustavo. Agências reguladoras, legalidade e direitos fundamentais: limites aos poderes normativo e sancionatório da Anvisa na Regulação de produtos fumígenos. In: ARAGÃO, Alexandre Santos de (Coord.). O poder normativo das agências reguladoras. Rio de Janeiro: Forense, 2006. p. 644.

146“ 'O Estado brasileiro chegou ao fim do século XX grande, troncho, ineficiente, com bolsões endêmicos de pobreza e de corrupção." BARROSO, Luís Roberto. Apontamentos sobre as agências reguladoras. In: MORAES, Alexandre (Org.). Agências reguladoras. São Paulo: Atlas, 2002. p. 110.

${ }^{147}$ GOMES, Joaquim Barbosa. Agências reguladoras: a "metamorfose" do Estado e da democracia - uma reflexão de direito constitucional comparado. In: BINENBOJM, Gustavo (Coord.). Agências reguladoras e democracia. Rio de Janeiro: Renovar, 2005. p. 30-31.

${ }^{148}$ Entretanto, importante salientar, conforme anuncia Maria Sylvia Zanella Di Pietro, que há notícia de que as agências reguladoras, sob denominação diversa, estariam inseridas em nosso sistema jurídico desde 1918 "No direito brasileiro, existem, desde longa data, entidades com função reguladora, ainda que sem a denominação de agências. Manoel Gonçalves Ferreira Filho, em trabalho sobre o papel das agências reguladoras e fiscalizadoras, publicado na revista Forum Administrativo, ano 1, no 3, p. 253-257, menciona, no início do século passado, no período 1930-1945, o Comissariado de Alimentação Pública (1918), o Instituto de Defesa Permanente do Café (1923), o Instituto do Açúcar e do Álcool (1933), o Instituto Nacional do Mate (1938), o Instituto Nacional do Pinho (1941), o Instituto Nacional do Sal (1940), todos esses institutos instituídos como autarquias econômicas, com a finalidade de regular a produção e o comércio.” DI PIETRO, Maria Sylvia Zanella. Direito administrativo, cit., p. 434. Por isso, conforme conclui Marçal Justen Filho, "que a criação de entidades denominadas de agências, na segunda metade de década de 90, não significou consagrar inovações absolutamente originais ou totalmente desconhecidas no universo legislativo brasileiro. Ao contrário, muitas dessas características eram praticadas no Direito brasileiro anterior, ainda que tal se fizesse por entidades não qualificadas formalmente como agências." JUSTEN FILHO, Marçal. op. cit., p. 329.

${ }^{149}$ Art. 21. Compete à União:

(...)

XI - explorar, diretamente ou mediante autorização, concessão ou permissão, os serviços de telecomunicações, nos termos da lei, que disporá sobre a organização dos serviços, a criação de um órgão regulador e outros aspectos institucionais; (Redação dada pela Emenda Constitucional nº 8, de 15/08/95:) 
os serviços de telecomunicações, nos termos da lei, que disporá sobre a organização dos serviços, a criação de um órgão regulador e outros aspectos institucionais”. Já o inciso III, do $\S 2^{\circ}$ do artigo 177, também da Constituição Federal ${ }^{150}$, autoriza a lei a dispor sobre "a estrutura e atribuições do órgão regulador do monopólio da União”, ao tratar do casos previstos nos incisos I a IV do mesmo artigo.

Afora as hipóteses acima tratadas, a criação das demais agências reguladoras vem se dando por meio de lei específica. ${ }^{151}$ A exemplo disso, temos a Lei n. ${ }^{\circ}$ 9.472, de 1997, que trata da organização dos serviços de telecomunicações, a criação e funcionamento de um órgão regulador e outros aspectos institucionais. Dispõe o artigo $8^{\circ}$ que "Fica criada a Agência Nacional de Telecomunicações, entidade integrante da Administração Pública Federal indireta, submetida a regime autárquico especial e vinculada ao Ministério das Comunicações, com a função de órgão regulador das telecomunicações, com sede no Distrito Federal, podendo estabelecer unidades regionais."

O artigo 174, da Constituição Federal, que confere ao Estado a alcunha de agente normativo e regulador da atividade econômica, a ele cabendo, na forma da lei, exercer "as funções de fiscalização, incentivo e planejamento, sendo este determinante para o setor público e indicativo para o setor privado", vem sendo apontado como a justificativa para a criação das agências reguladoras.

A fim de dar meios ao Estado para buscar cumprir com este papel, o legislador autoriza a criação, por meio de lei específica, de certas entidades, conforme abaixo:

Art. 37. A administração pública direta e indireta de qualquer dos Poderes da União, dos Estados, do Distrito Federal e dos Municípios obedecerá aos princípios de legalidade, impessoalidade, moralidade, publicidade e eficiência e, também, ao seguinte: (Redação dada pela Emenda Constitucional $\mathrm{n}^{\mathrm{o}} 19$, de 1998).

XIX - somente por lei específica poderá ser criada autarquia e autorizada a instituição de empresa pública, de sociedade de economia mista e de fundação, cabendo à lei complementar, neste último caso, definir as áreas de sua atuação; (Redação dada pela Emenda Constitucional $\mathrm{n}^{\circ} 19$, de 1998).

\footnotetext{
${ }^{150}$ Art. 177. Constituem monopólio da União:

(...)

$\S 2^{\circ}$ A lei a que se refere o $\S 1^{\circ}$ disporá sobre: (Incluído pela Emenda Constitucional no 9, de 1995)

(...)

III - a estrutura e atribuições do órgão regulador do monopólio da União; (Incluído pela Emenda Constitucional $\mathrm{n}^{\circ}$ 9, de 1995)

${ }^{151}$ Pois, conforme já salientado, dispõe o artigo $5^{\circ}$, inciso I, do Decreto-Lei n. ${ }^{\circ}$ 200/1967, que toda autarquia será criada por lei.
} 
Diante do exposto, podemos concluir que as agências reguladoras são órgãos criados por lei, e cuja finalidade é regular e fiscalizar a atividade específica que lhe está afeta, explicitamente prevista na lei que a criou. São, ainda, entidades da Administração Indireta, criadas sob a roupagem de autarquia sob regime especial, e vinculadas ao ministério supervisor, competente para tratar da respectiva atividade. ${ }^{152}$

Aos seus dirigentes é garantido mandato fixo, vedada a possibilidade de exoneração ad nutum $^{153}$, conforme previsto nos artigos $5^{\circ}$ caput e $\S$ único ${ }^{154}, 6^{\mathrm{o} 155}$ e $9^{\text {o156 }}$, da Lei n. ${ }^{\circ}$ 9.986 de 2000, que dispõe sobre a gestão de recursos humanos das agências reguladoras.

Quanto à autonomia financeira, as agências possuem, além das dotações orçamentárias gerais, fontes próprias de recursos, conforme exemplifica Leila Cuéllar: ${ }^{157}$ (a) arrecadação de taxa de fiscalização sobre os serviços ou atividades econômicas regulados; (b) produtos de multas, emolumentos e retribuição de serviços prestados a terceiros; (c) rendimentos de operações financeiras; (d) recursos provenientes de convênios, acordos ou contratos celebrados; (e) doações, legados, dentre outros recursos que lhe forem destinados; (f) valores apurados na venda ou aluguel de bens móveis ou imóveis de propriedade das agências.

Por fim, quanto às decisões por elas tomadas, são, em regra, de caráter final ${ }^{158}$, podendo apenas serem revistas pelo Poder Judiciário, em atenção ao artigo $5^{\circ}$, inciso XXXV, da Constituição, que assim determina: "a lei não excluirá da apreciação do Poder Judiciário lesão ou ameaça de direito". 159

${ }^{152}$ Citamos, como exemplo, a Agência Nacional de Telecomunicações (ANATEL), cuja vinculação se dá ao Ministério das Comunicações (artigo $8^{\circ}$, da Lei n. ${ }^{\circ}$ 9.472/1997).

153“ À vontade, pela vontade. Ao menor.” SILVEIRA, José Roberto da. Brocados latinos: termos jurídicos. São Paulo: Leud, 2006. p. 11.

${ }^{154}$ Art. $5^{\circ}$. O Presidente ou o Diretor-Geral ou o Diretor-Presidente (CD I) e os demais membros do Conselho Diretor ou da Diretoria (CD II) serão brasileiros, de reputação ilibada, formação universitária e elevado conceito no campo de especialidade dos cargos para os quais serão nomeados, devendo ser escolhidos pelo Presidente da República e por ele nomeados, após aprovação pelo Senado Federal, nos termos da alínea $\mathrm{f}$ do inciso III do art. 52 da Constituição Federal.

Parágrafo único. O Presidente ou o Diretor-Geral ou o Diretor-Presidente será nomeado pelo Presidente da República dentre os integrantes do Conselho Diretor ou da Diretoria, respectivamente, e investido na função pelo prazo fixado no ato de nomeação.

${ }^{155}$ Art. $6^{\circ}$. O mandato dos Conselheiros e dos Diretores terá o prazo fixado na lei de criação de cada Agência.

${ }^{156}$ Art. $9^{\circ}$. Os Conselheiros e os Diretores somente perderão o mandato em caso de renúncia, de condenação judicial transitada em julgado ou de processo administrativo disciplinar.

${ }^{157}$ CUÉLLAR, Leila. op. cit., p. 136.

${ }^{158}$ DI PIETRO, Maria Sylvia Zanella. Parcerias na administração pública: concessão, permissão, franquia, terceirização e outras formas, cit., p. 141-142.

159،"Esse dispositivo significa a adoção, no direito brasileiro, do sistema de unidade de jurisdição, ao contrário de outros países que seguiram o direito francês e adotaram o sistema da dualidade de jurisdição, que admite, ao lado da jurisdição comum, a jurisdição administrativa, com competência para dirimir conflitos 


\subsubsection{Agências reguladoras ou regulamentadoras?}

Um dos problemas talvez insolúveis do direito positivo é a vagueza e frequente ambiguidade com que os seus institutos, formas e locuções prescritivas se apresentam. $\mathrm{O}$ preço do regime democrático é a ordem jurídica expressa numa linguagem muitas vezes imprecisa e falha, e muito disso se deve ao caráter pluralista de seu corpo legislativo, formado por representantes populares com todo o tipo de formação (ou falta de). Trata-se de um preço que, na lógica custo-benefício, vale a pena pagar, uma vez que a democracia, como certa feita disse Winston Churchill ${ }^{160}$, "é a pior forma de governo, salvo todas as demais formas que têm sido experimentadas de tempos em tempos".

Se o direito positivo, principalmente em sua porção legislativa, é carregado de indeterminações e falhas linguísticas, tais como redundâncias, ambiguidades e até mesmo contradições, o mesmo não se pode admitir na Ciência Jurídica. O discurso científico que portar vícios e descuidos na linguagem em que se manifesta não logrará cumprir com seu principal objetivo, qual seja, descrever a realidade.

Portanto, como ensina Norberto Bobbio, o "rigoroso cuidado na terminologia não é exigência ditada pela gramática para a beleza do estilo, mas é uma exigência fundamental para construir qualquer ciência". 161

É, portanto, imprescindível para o desenvolvimento do que aqui pretendemos tratar, o estabelecimento de certas premissas e definições, a fim de, partindo destas, ser possível descrever com o máximo de precisão possível o objeto de análise, que é, no presente item, os limites do alcance normativo das agências. Trata-se de cautela muito bem-vinda, notadamente ao ventilarmos questões acerca do verdadeiro alcance da competência normativa das agências no direito brasileiro.

Dito isso, iniciamos este ponto do trabalho relembrando, conforme já visto em capítulo anterior, que regular significa dirigir a ação humana. Consubstancia, para o

\footnotetext{
de interesse envolvendo a Administração Pública, com força de coisa julgada.” DI PIETRO, Maria Sylvia Zanella. Direito administrativo, cit., p. 437.

160"Democracy is the worst form of government except from all those other forms that have been tried from time to time." Em discurso na Casa dos Comuns, em 11 de novembro de 1947. SELECTED Speeches of Winston Churchill. Disponível em: <http://www.winstonchurchill.org/learn/speeches/speeches-of-winstonchurchill>. Acesso em: 20 nov. 2011.

${ }^{161}$ Teoria della Scienza Giuridica. Torino: Giappichelli, 1950, p. 51. Apud CARVALHO, Paulo de Barros. Curso de direito tributário. 22. ed. São Paulo: Saraiva, 2010. p. 309.
} 
direito, o regramento que cria direitos e deveres correlatos dirigidos ao cidadão, de forma a nortear a sua conduta na direção pretendida pelo ordenamento jurídico.

Mas, portanto, o que seria uma agência reguladora, segundo esta acepção de regular? Já sabemos que, quanto à natureza jurídica, as agências são autarquias sob regime especial cuja finalidade é regular matéria específica que lhe está legalmente afeta. Quanto ao alcance de sua atuação, poderíamos compreender que este órgão está revestido de competência para editar normas jurídicas inovadoras no sistema, criando novos direitos e obrigações àqueles inseridos em seu âmbito de atuação.

Entretanto, não obstante sejam estes órgãos denominados de agências reguladoras, nos cabe aqui averiguar se de fato suas atuações se pautam pela regulação ou, não obstante suas denominações, sua competência é, na verdade, dirigida à regulamentação das matérias previstas nas respectivas leis instituidoras.

Para enfrentarmos esta questão, iniciaremos pontuando que, muito embora os vocábulos regular e regulamentar comportem distintas acepções, por vezes sua utilização peca pela imprecisão, a ponto de serem empregados como sinônimos. ${ }^{162}$

Assim, nos cabe, primeiramente, pontuar o que compreendemos por regulamento e regulamentar, pela ótica jurídica. Pelo substantivo "regulamento" entende-se, nos termos do inciso IV, do artigo 84, da Constituição Federal, como o veículo introdutor de normas jurídicas específico, de competência privativa do Chefe do Executivo Federal:

Art. 84. Compete privativamente ao Presidente da República:

(...)

IV - Sancionar, promulgar e fazer publicar as leis, bem como expedir decretos e regulamentos para sua fiel execução.

Podemos chamar esta competência de competência regulamentar. Trata-se de função típica do Poder Executivo, haja vista que a ele caberá, para fiel execução das leis, expedir regulamentos.

Da leitura literal do inciso IV, do artigo 84 , da Constituição Federal, conclui-se que apenas ao Chefe do Poder Executivo é atribuída a função regulamentar. Neste sentido

\footnotetext{
${ }^{162}$ PINHEIRO, Armando Castelar; SADDI, Jairo. op. cit., p. 254. Isso ocorre, inclusive, em dicionários ao consultarmos o verbete "regulamentar": "regular; estabelecer regulamento ou norma (...)." CALDAS Aulete. 5. ed. Rio de Janeiro: Delta S/A, 1964.
} 
manifesta-se Celso Antônio Bandeira de Mello ${ }^{163}$, ao conceituar regulamento, destacando que a sua titularidade é exclusiva dos chefes dos Poderes Executivos. ${ }^{164}$

Já quanto à definição de regulamento, também não há assentamento pacífico na doutrina. Pontes de Miranda, ${ }^{165}$ ao comentar o inciso III, artigo 81, da Constituição Federal de 1967, que carrega a exata redação do acima transcrito inciso IV, do artigo 84, da Constituição de 1988, assim assevera:

Onde se estabelecem, alteram ou extinguem direitos, não há regulamentos - há abuso de poder regulamentar, invasão da competência do Poder Legislativo. O regulamento não é mais do que auxiliar das leis, auxiliar que sói pretender, não raro, o lugar delas, mas sem que possa, com tal desenvoltura, justificar-se, e lograr que o elevem à categoria de lei. (...) Se o regulamento cria direitos ou obrigações novas, estranhas à lei, ou faz reviverem direitos, deveres, pretensões, obrigações, ações ou exceções, que a lei apagou, é inconstitucional. (...) Tampouco pode ele limitar, modificar ou ampliar direitos, deveres, pretensões, obrigações, ações ou exceções. Não pode facultar o que na lei se proíbe, nem lhe procurar exceções à proibição, salvo se estão implícitas. Nem ordenar o que a lei não ordena.

Portanto, para o ilustre jurista, a função dos regulamentos jamais deve ser confundida com a função das leis. ${ }^{166}$ Aos regulamentos é atribuído o papel de apenas operacionalizar o disposto na norma legal.

Neste mesmo sentido posiciona-se Marcello Caetano ${ }^{167}$, ao afirmar que:

(...) em sentido material o regulamento tem afinidades com a lei em virtude da sua generalidade, pois os regulamentos possuem sempre caráter genérico. Mas distingue-se dela por lhe faltar novidade, visto as suas normas serem, pelo que toca à limitação de direitos individuais,

\footnotetext{
${ }^{163}$ MELLO, Celso Antônio Bandeira de. op. cit., p. 311.

${ }^{164}$ Neste mesmo sentido, Diógenes Gasparini: "atribuição privativa do chefe do Poder Executivo para, mediante decreto, expedir atos normativos, chamados regulamentos, compatíveis com a lei e visando desenvolvê-la." GASPARINI, Diógenes. Direito administrativo. 9. ed. São Paulo: Saraiva, 2004. p. 117.

${ }^{165}$ A disposição contido no inciso IV do artigo 84, da Constituição Federal de 1988, não é novidade em nosso ordenamento. Esta mesma norma já se encontrava prevista no artigo 102, inciso XII, da Constituição de 1824 e no artigo 48, $1^{\circ}$, da Constituição de 1891; artigo 56, § $1^{\circ}$, da Constituição de 1934; artigo 74, “a”, da Constituição de 1937; artigo 87, I, da Constituição de 1946; e artigo 83, II, da Constituição de 1967. Portanto, não obstante o período de tempo passado desde os comentários de Pontes de Miranda, tratam-se de observações pertinentes, visto que a norma não apenas ainda subsiste em nosso ordenamento jurídico, como também mantém redação similar. PONTES DE MIRANDA, Francisco Cavalcanti. Comentários à Constituição de 1967 com a Emenda n. 1, de 1969. 2. ed. São Paulo: Ed. Revista dos Tribunais, 1973. t. 3, p. 314-316.

${ }^{166}$ Conforme salienta Geraldo Ataliba, "a lei tem cunho inaugural, inovador - e o regulamento é ato menor, inferior, de aplicação. É ato secundário e, pois, meramente administrativo". ATALIBA. Geraldo. República e Constituição. 2. ed. São Paulo: Malheiros Ed., 2001. p. 136.

${ }^{167}$ CAETANO, Marcello. Manual de direito administrativo. 10. ed. Coimbra: Almedina, 1997. v. 1, p. 97.
} 
simples desenvolvimento ou aplicação de outras normas, essas inovadoras. (grifos do autor).

Diogo Freitas do Amaral $^{168}$ classifica o regulamento como norma secundária, ao informar que encontra na lei seu embasamento e parâmetro de validade. Discorre que "a atividade regulamentar é uma atividade subordinada e condicionada face à actividade legislativa, essa livre, primária e independente." Complementa Egon Bockmann Moreira ${ }^{169}$, dizendo que "não é viável que a autoridade administrativa inaugure a ordem jurídica através da emanação de regras que restrinjam o universo de direitos constitucional e/ou legalmente assegurados aos administrados".

Em sentido diverso, que compreende o regulamento como norma dotada de maior abrangência, lembramos Caio Tácito ao afirmar que "regulamentar não é somente reproduzir analiticamente a lei, mas ampliá-la e completá-la, segundo o seu espírito e o seu conteúdo, sobretudo nos aspectos que a própria lei, expressa ou implicitamente, outorga à esfera regulamentar." 170

Quanto à classificação do regulamento, pode-se encontrar na doutrina, basicamente, três modalidades ${ }^{171}$, a saber: (a) regulamento autônomo; (b) regulamento de execução; e (c) regulamento delegado.

Resumidamente, os regulamentos autônomos são atos normativos expedidos pelo Poder Executivo, que asseguram a realização de atribuições específicas, sem com isso estarem completando o conteúdo de lei específica. ${ }^{172}$ Trata-se de poder para regulamentar "matérias de que o legislador não achou dever tratar."

Representa, portanto, uma espécie de regulamento que tem como base a competência própria do Poder Executivo de editar normas, sem que neste processo esteja presente a figura do Poder Legislativo. Ou, ainda, nas palavras de Oswaldo Aranha

\footnotetext{
${ }^{168} \mathrm{O}$ autor utiliza a denominação regulamento de execução como sinônimo de regulamento complementar, visto que a tarefa por ele desempenhada de "pormenorização, de detalhe e de complemento" da norma legal é o que o caracteriza. AMARAL, Diogo Freitas do. Direito administrativo. Lisboa: Coimbra Ed., 1989. v. 3 , p. 17-18.

${ }^{169}$ MOREIRA, Egon Bockmann. Processo administrativo: princípios constitucionais e a Lei 9.784/1999. 2. ed. São Paulo: Malheiros Ed., 2003. p. 267.

${ }^{170}$ TÁCITO, Caio. Comissão de Valores Mobiliários. Poder Regulamentar. In: Temas de direito público. Rio de Janeiro: Renovar, 1997. v. 2, p. 1079.

171“ "Quem não se recusa a conhecer a realidade sabe que existem, no direito positivo brasileiro, três tipos de regulamentos: os de execução, os equivocadamente chamados de 'delegados' e os autônomos." (grifos do autor) GRAU, Eros Roberto. op. cit., p. 187.

${ }^{172}$ AMARAL, Diogo Freitas do. op. cit., v. 3, p. 20-21.

${ }^{173}$ RIVERO, Jean. Direito administrativo. Coimbra: Almedina, 1981. p. 63-64.
} 
Bandeira de Mello ${ }^{174}$, "são verdadeiras leis, e assim chamados tão somente porque emanados pelo Poder Executivo, pois não constituem desenvolvimento de qualquer lei ordinária, mas correspondem ao exercício da prerrogativa de legislar a ele reconhecida com base no Direito Constitucional".

Salienta-se que a possibilidade de existência de regulamentos autônomos no direito brasileiro é bastante debatida. Para Eros Roberto $\mathrm{Grau}^{175}$, ao elencar os regulamentos presentes no Brasil, aponta o regulamento autônomo, assim o caracterizando:

Regulamentos autônomos ou independentes, que são os que, decorrendo de atribuição do exercício de função normativa implícita no texto constitucional, importam o exercício daquela função pelo Executivo para o fim de viabilizar a atuação, dele, no desenvolvimento de função administrativa de sua competência; envolvem, quando necessário, inclusive a criação de obrigação de fazer ou deixar de fazer alguma coisa. (grifos do autor).

Já para Geraldo Ataliba ${ }^{176}$, não haveria como se falar em regulamento autônomo no direito brasileiro:

É até ridículo que um brasileiro, tratando da faculdade regulamentar, à luz do nosso direito, abra um tópico sob tal designação. Tão ridículo como seria criar um capítulo sobre a inspiração de Alah a ação dos seus delegados-governantes. Nos dois casos, a finalidade de menção seria afirmar o não cabimento do próprio estudo, pela inexistência de reconhecimento constitucional a esses institutos.

Por conseguinte, temos os chamados regulamentos de execução, como a própria denominação sugere, são aqueles que explicitam o conteúdo das leis, de forma a viabilizar sua efetiva aplicação. ${ }^{177}$

Esses regulamentos de execução podem ser classificados como espontâneo ou a convite. Marcello Caetano ${ }^{178}$ os diferencia definindo o primeiro como aquele regulamento feito pela autoridade administrativa "sem sugestão ou convite do órgão legislativo, apenas para satisfazer a necessidade de disciplinar a execução da lei”, e o segundo, como aquele decorrente de convite pelo legislador, "quando a lei contém uma disposição em que

\footnotetext{
${ }^{174}$ MELLO, Oswaldo Aranha Bandeira de. Princípios gerais de direito administrativo. 2. ed. Rio de Janeiro: Forense, 1979. v. 1, p. 342-343.

${ }^{175}$ GRAU, Eros Roberto. op. cit., p. 189.

${ }^{176}$ ATALIBA, Geraldo. Poder regulamentar no executivo. Revista de Direito Público. São Paulo, v. 14, n. 5758, p. 197, 1981.

${ }^{177}$ AMARAL, Diogo Freitas do. op. cit., v. 3, p. 18.

${ }^{178}$ CAETANO, Marcello. op. cit., v. 1, p. 99.
} 
expressamente estabelece que tal órgão elaborara os regulamentos necessários à execução dela".

E, por fim, temos o regulamento delegado, também denominado de regulamento autorizado. São aqueles regulamentos que tratam de matérias que, muito embora não estejam detalhadamente disciplinadas em lei formal, nela encontram seu fundamento de validade.

São, portanto, regulamentos editados pelo Poder Executivo em face de atribuição pelo Poder Legislativo. Trata-se de situação na qual o legislativo limita-se a fixar princípios gerais a serem observados pela autoridade administrativa, que deverá disciplinar a matéria que constitui seu objeto, por meio do exercício de sua competência normativa, e não de delegação de função legislativa. Daí a posição de Eros Grau, ao inferir que tais regulamentos não decorrem de nenhuma delegação de função e que, portanto, são equivocadamente nomeados de regulamentos delegados, ao invés de regulamentos autorizados. $^{179}$

Já o verbo regulamentar é o que padece de maior sinonímia e indeterminação, inclusive no que se refere à competência normativa das agências. A acepção mais comum, contudo, é que regulamentar refere-se ao ato de explicitar e dar operatividade às normas legais, sendo que ao exercício de tal ação é vedado inovar na ordem jurídica, prerrogativa que seria exclusiva das leis.

Destarte, é esta a acepção que empregamos para o verbo, no sentido de ser esta a função precípua de normas infralegais que visam a dar operatividade às leis. Sendo assim, esta seria a função de todo ato normativo infralegal, tais como o regulamento propriamente dito, as instruções, deliberações, portarias e pareceres. Portanto, sempre que normas administrativas não puderem inovar, mas tão somente explicitar e operacionalizar comandos legislativos, estaremos diante de uma autêntica função regulamentadora, ainda que presente em outros veículos infralegais. A função regulamentadora, sendo assim, própria da espécie de regulamento denominado executivo, estaria presente não apenas nesse veículo introdutor específico, mas também nos demais veículos infralegais.

Concluindo, delimitar os contornos semânticos dos vocábulos regular e regulamentar é pertinente às reflexões que apresentaremos não apenas para fixar suas definições de forma a evitar o uso indiscriminado dos termos, mas também porque,

${ }^{179}$ GRAU, Eros Roberto. op. cit., p. 188. 
conforme a seguir veremos, não há na doutrina um consenso acerca dos limites da atuação normativa das agências. Há quem defenda que a elas cabe a função de apenas regulamentar, como há também aqueles que se posicionam pela possibilidade de regular. Daí a necessidade de fixação precisa dos significados dos termos em tela.

Em muito esta discussão se deve ao fato de as agências terem nascido em decorrência de uma importação do instituto das agencies estadunidenses, sem que, contudo, os devidos ajustes a fim de adaptá-las ao sistema jurídico brasileiro tenham sido feitos. Como vimos, se mesmo no sistema mais flexível e pragmático da Common Law o poder normativo das agências estadunidenses foi intensamente debatido por décadas, no Brasil, herdeiro de uma tradição ibérica altamente formalista, a "tropicalização" de uma instituição como essa não poderia ser fácil. Em nosso tipo de sistema, parece ser mais desejável adaptar os fatos às teorias do que descartar as teorias falhas em prol da realidade. Ou seja, em termos fáticos, as agências vêm inovando no sistema jurídico, por meio da criação de novos direitos e deveres. O que cabe perguntar é se podem fazê-lo e à luz da nossa ordem constitucional, e se puderem, até onde vai tal poder. Por enquanto, nos limitaremos a expor diferentes posições doutrinárias acerca do problema.

Podemos encontrar na doutrina pelo menos quatro teorias acerca da competência normativa das agências que se destacam. Apresentaremos, ainda que brevemente, a fundamentação teórica central de cada uma delas, bem como seus principais representantes e críticas.

Salientamos, entretanto, que não pretendemos aqui esgotar todas as correntes e posições doutrinárias acerca do tema, mas cabe expor algumas linhas de grande força retórica. Em ordem meramente aleatória, a primeira delas poderia ser denominada de legitimação pela função. Esta linha de pensamento admitiria a existência do regulamento autônomo em nosso sistema pelo argumento de que a Constituição atribuiria a consecução de determinados fins ao Executivo e, para tanto, autorizaria, ainda que implicitamente, o uso de tal veículo normativo. Nessa corrente, pode-se citar Eros Roberto Grau ${ }^{180}$, para quem "os regulamentos autônomos ou independentes são emanados a partir de atribuição implícita do exercício de função normativa ao Executivo, definida no texto constitucional ou decorrente de sua estrutura".

${ }^{180}$ GRAU, Eros Roberto. op. cit., p. 188. 
A segunda corrente seria a da delegificação ou deslegalização, pela qual existiria uma transferência de função normativa específica sobre certas matérias, do Poder Legislativo ao Poder Executivo, com ênfase às agências reguladoras. ${ }^{181}$ Em essência e da mesma forma que a linha anterior, trata-se de uma legitimação pela função, uma vez ser esta a justificativa para a referida transferência. Como representante dessa linha, Diogo Figueiredo. $^{182}$

Uma terceira vertente leva à ideia de generalidade das normas legais regulatórias, e tem dentre seus próceres, Carlos Ari Sundfeld. ${ }^{183}$ Uma vez que os setores regulados usualmente são de grande dinamismo, as normas legais são propositadamente abertas, de modo que o órgão regulador possa especificá-las frente às situações concretas, por intermédio de normas infralegais. Note-se que as regras regulatórias legais não seriam propriamente cláusulas gerais, aquelas normas jurídicas de tal indeterminação que mesmo a sua aplicação por vezes acarreta incerteza e insegurança jurídicas, mas sim normas suficientemente abertas a possibilitar tal concreção executiva.

Por fim, uma quarta e (para fins meramente expositivos) última corrente seria encabeçada por Marçal Justen Filho, pela qual a competência normativa das agências reguladoras seria uma manifestação da discricionariedade administrativa conferida pela lei. Para esse autor, o princípio da legalidade quase sempre manifesta-se em sua dimensão "comum", i.e., é atendido quando o legislador "inaugura" a inovação no sistema jurídico, criando direitos e deveres e delimitando o alcance das condutas consideradas como obrigatórias, proibidas e permitidas. Feito isso, a lei poderia então atribuir à autoridade administrativa a competência para, discricionariamente, porém balizada pelos limites legais, especificar as normas de forma a dar conta das vicissitudes do setor regulado. Por outro lado, tal competência normativa da Administração não seria capaz de verdadeiramente inovar na ordem jurídica, nos casos de silêncio legislativo, pois tal

\footnotetext{
${ }^{181}$ Marçal Justen Filho salienta a Ação Direta de Inconstitucionalidade n. ${ }^{\circ} 1.668$, na qual o Supremo Tribunal Federal afastou a tese da deslegalização, por entender que a competência da ANATEL seria infralegal e que, portanto, sua atividade normativa estaria sujeita à observância das normas previstas na Lei de Licitações. JUSTEN FILHO, Marçal. op. cit., p. 538-539.

${ }^{182}$ MOREIRA NETO, Diogo Figueiredo. Natureza jurídica: competência normativa. Limites de atuação. RDA, n. 215, p. 79, jan./mar. 1999. Para o autor, haveria a transferência de função normativa, sobre determinadas matérias de um poder ao outro, principalmente no que se refere aos órgãos reguladores.

${ }^{183}$ SUNDFELD, Carlos Ari. A administração pública na era do direito global. In: SUNDFELD, Carlos Ari; VIEIRA, Oscar Vilhena (coords.). Direito global. São Paulo: Max Limonad, 1999. p. 166. ARAGÃO, Alexandre Santos de. Agências reguladoras e a evolução do direito administrativo econômico. 2. ed. Rio de Janeiro: Forense, 2006. p. 406.
} 
exercício normativo ultrapassaria os limites da sua discricionariedade. ${ }^{184}$

Do lado oposto à possibilidade de qualquer forma de inovação deôntica das agências encontram-se importantes doutrinadores, como Celso Antônio Bandeira de Mello $^{185}$ e Maria Sylvia de Pietro ${ }^{186}$, que lhes negam tal prerrogativa. Para estes autores, a Constituição Federal erigiu como valor supremo o princípio da legalidade, de forma que todo direito e dever só poderá ser criado por veículo legal, restando à Administração Pública a função de expedir regras que meramente explicitem e operacionalizem tais comandos.

Em exposição sintética, essas são possivelmente as mais significativas vertentes doutrinárias a respeito do tema. Os tribunais superiores pouco se manifestaram a respeito, mas o fato inconteste é que as agências reguladoras vêm inovando, por diversas vezes, no ordenamento jurídico. Em relação ao tema desta dissertação, cabe verificar a situação da Comissão de Valores Mobiliários no contexto dessa problemática, conforme será exposto nos tópicos seguintes deste.

\subsubsection{A Comissão de Valores Mobiliários como autarquia responsável pelo mercado de capitais}

A Comissão de Valores Mobiliários foi criada, conforme já relatado em capítulo anterior, em um contexto de crise, no qual se buscava uma resposta à insegurança que havia se instaurado no mercado de capitais brasileiro no início da década de 1970. Uma das medidas adotadas foi a criação de órgão especializado, com a finalidade de regular e desenvolver o mercado, a fim de restaurar a instituição e afastar as incertezas advindas da crise.

O nascimento da CVM se deu por meio da Lei n. ${ }^{\circ} 6.385$, de 7 de dezembro de 1976, cuja finalidade foi dispor sobre o mercado de valores e criar a Comissão de Valores Mobiliários. Seu texto original, até hoje já modificado por onze outros diplomas ${ }^{187}$, trazia consigo em seu artigo $5^{\circ}$ a seguinte redação: "É instituída a Comissão de Valores

\footnotetext{
${ }^{184}$ JUSTEN FILHO, Marçal. op. cit., p. 510.

${ }^{185}$ MELLO, Celso Antônio Bandeira de. op. cit., p. 159.

${ }^{186}$ DI PIETRO, Maria Sylvia Zanella. Direito administrativo, cit., p. 438-439.

${ }^{187}$ Decreto Autônomo n. ${ }^{\circ}$ 3.995/2001; Lei n. ${ }^{\circ}$ 6.422/1977; Lei n. ${ }^{\circ}$ 6.616/1978; Lei n. ${ }^{\circ}$ 9.447/1997; Lei n. ${ }^{\circ}$ 9.457/1997; Lei n. ${ }^{\circ}$ 9.873/1999; Lei n. ${ }^{\circ}$ 10.198/2001; Lei n. ${ }^{\circ} 10.303 / 2001$; Lei n. ${ }^{\circ} 10.411 / 2002$; Lei n. $^{\circ}$ 11.638/2007; Lei n. ${ }^{\circ} 12.543 / 2011$.
} 
Mobiliários, entidade autárquica, vinculada ao Ministério da Fazenda." Foi assim, portanto, que a CVM foi criada: como uma autarquia vinculada ao Ministério da Fazenda.

Quanto à composição da sua administração, dispunha a redação original do artigo 6o que seria composta, por meio da indicação do Presidente da República, por um presidente e quatro diretores (caput). Os membros da diretoria eram demissíveis ad nutum (§ 10).

Em 31 de outubro de 2001, foi instituída a Medida Provisória $n^{\circ} 8$, que tinha como desígnio a alteração de dispositivos da Lei do Mercado de Capitais, a fim de atualizar aqueles referentes à atuação, composição e competência da CVM.

Dentre as alterações propostas cumpre-nos salientar duas: uma referente à atuação da Comissão, e a segunda pertinente à sua composição.

A primeira, referente à sua atuação, deu-se por meio da alteração do referido artigo $5^{\circ}$. Esta mudança propôs elevar a Comissão ao status de autarquia sob regime especial, ou seja, dotá-la de personalidade jurídica e patrimônio próprios, autoridade administrativa independente, ausência de subordinação hierárquica, mandato fixo e estabilidade de seus dirigentes, e autonomia financeira e orçamentária. Segue abaixo a redação da norma:

Art. 5\%. É instituída a Comissão de Valores Mobiliários, entidade autárquica em regime especial, vinculada ao Ministério da Fazenda, com personalidade jurídica e patrimônio próprios, dotada de autoridade administrativa independente, ausência de subordinação hierárquica, mandato fixo e estabilidade de seus dirigentes, e autonomia financeira e orçamentária.

Quanto a segunda mudança, voltada à composição da CVM, se deu por meio, inicialmente, da parte final do artigo $5^{\circ}$, na qual foi conferido a seus dirigentes mandato fixo e estabilidade, bem como pela alteração da redação do também já referido artigo $6^{\circ}$. Com isso, restou dependente a nomeação de seus dirigentes pelo Presidente da República à prévia aprovação pelo Senado Federal (caput). Ademais, conferiu aos dirigentes mandatos fixos de cinco anos $\left(\S 1^{\circ}\right)$, condicionando a perda do cargo à renúncia, condenação judicial transitada em julgado ou processo administrativo disciplinar $\left(\S 2^{\circ}\right)$, nos seguintes termos:

Art. $6^{\circ}$. A Comissão de Valores Mobiliários será administrada por um Presidente e quatro Diretores, nomeados pelo Presidente da República, depois de aprovados pelo Senado Federal, dentre pessoas de ilibada reputação e reconhecida competência em matéria de mercado de capitais.

$\S 1^{\circ} \mathrm{O}$ mandato dos dirigentes da Comissão será de cinco anos, vedada a recondução, devendo ser renovado a cada ano um quinto dos membros do Colegiado. 
$\S 2^{\circ}$ Os dirigentes da Comissão somente perderão o mandato em virtude de renúncia, de condenação judicial transitada em julgado ou de processo administrativo disciplinar.

$\S 3^{\circ}$ Sem prejuízo do que preveem a lei penal e a lei de improbidade administrativa, será causa da perda do mandato a inobservância, pelo Presidente ou Diretor, dos deveres e das proibições inerentes ao cargo.

$\S 4^{\circ}$ Cabe ao Ministro de Estado da Fazenda instaurar o processo administrativo disciplinar, que será conduzido por comissão especial, competindo ao Presidente da República determinar o afastamento preventivo, quando for o caso, e proferir o julgamento.

$\S 5^{\circ}$ No caso de renúncia, morte ou perda de mandato do Presidente da Comissão de Valores Mobiliários, assumirá o Diretor mais antigo ou o mais idoso, nessa ordem, até nova nomeação, sem prejuízo de suas atribuições.

$\S 6^{\circ}$ No caso de renúncia, morte ou perda de mandato de Diretor, proceder-se-á à nova nomeação pela forma disposta nesta Lei, para completar o mandato do substituído.

Esta Medida Provisória, após a prorrogação de sua vigência, nos termos do $\S 7^{\circ}$ do artigo 62, da Constituição Federal, foi, em 26 de fevereiro de 2002, convertida na Lei n. ${ }^{\circ}$ 10.411. Com isso, promoveu-se a alteração das redações originais dos artigos $5^{\circ}$ e $6^{\circ}$.

Entretanto, embora a Medida Provisória $n^{\circ} 8$ tenha sido convertida em lei, muito questionou-se, à época, a sua constitucionalidade. Cabe investigar o histórico da criação desta norma, para verificarmos a procedência desses questionamentos.

Em maio de 1997, foi apresentado pelo Deputado Luiz Carlos Hauly à Câmara dos Deputados o Projeto de Lei que lá restou classificado com o n. ${ }^{0} 3.115$. Dentre as propostas nele contidas, encontravam-se os dois dispositivos acima tratados (artigos $5^{\circ}$ e $6^{\circ}$, da Lei n. ${ }^{\circ}$ 6.385/1976), que visavam a alteração de questões referentes à atuação e composição da Comissão de Valores Mobiliários.

No ano de 2001, ao longo do curso de sua tramitação, o texto, então classificado como o Projeto de Lei da Câmara $n^{0} 23$, chega ao Presidente da República. No uso da atribuição a ele conferida pelo $\S 1^{\circ}$ do artigo 66 , da Constituição Federal, ${ }^{188}$ o Chefe do

\footnotetext{
${ }^{188}$ Art. 66. A Casa na qual tenha sido concluída a votação enviará o projeto de lei ao Presidente da República, que, aquiescendo, o sancionará.

$\S 1^{\circ}$ - Se o Presidente da República considerar o projeto, no todo ou em parte, inconstitucional ou contrário ao interesse público, vetá-lo-á total ou parcialmente, no prazo de quinze dias úteis, contados da data do recebimento, e comunicará, dentro de quarenta e oito horas, ao Presidente do Senado Federal os motivos do veto.
} 
Poder Executivo decide vetar parcialmente a proposta, em razão de inconstitucionalidade e contrariedade ao interesse público. ${ }^{189}$

Justificou o veto do artigo $5^{\circ}$, que conferia especialidade à autarquia, da seguinte forma:

O dispositivo não pode ser acolhido, uma vez que compete privativamente ao Presidente da República iniciar o processo legislativo para dispor sobre a criação de órgãos da administração pública (art. 61, § $1^{\circ}$, II, "e"). Poder-se-á arguir que não se trata de criação, já que subsiste a CVM. Entretanto, assim não nos parece, e isso porque a alteração da natureza jurídica da entidade, que passará a ser a de autarquia especial, sem subordinação hierárquica, acarreta, na verdade, a extinção da hoje existente CVM e a criação de nova entidade, ainda que se mantenha a mesma nomenclatura da anterior. Evidentemente, mudada a essência, mudada a pessoa jurídica.

Já quanto ao veto do artigo $6^{\circ}$, que versava sobre nomeação e mandato dos dirigentes da Comissão de Valores Mobiliários, a justificativa se deu nos termos abaixo:

$\mathrm{O}$ art. $6^{\circ}$ da Lei $\mathrm{n}^{\circ} 6.385$, de 1976 , que inclui requisito para a nomeação do presidente e dos diretores da autarquia, estabelecendo para esses prazo de mandato, não deve ser aceito, uma vez que compete ao Presidente da República privativamente iniciar as leis que disponham sobre servidores públicos, regime jurídico e provimento de cargos desses (art. $61, \S 1^{\circ}$, II, "c"). Ora, estabelecido novo requisito para a nomeação, alteram-se as regras de provimento do cargo, e estabelecido mandato, modificam-se as normas para a exoneração deste, matéria essa afeita ao regime jurídico do servidor. E não se diga que quem possui mandato não é servidor, e isso porque todo aquele que ocupa cargo público é assim considerado. Quanto a regra contida no $\S 5^{\circ}$ deste artigo que estabelece a "quarentena" para os ex-dirigentes da CVM, além de ferir o princípio da iniciativa, acarreta despesa, não podendo, portanto, ser acatada sequer sob a ótica da convalidação.

Ocorre que, à época da tramitação do Projeto de Lei n. ${ }^{\circ}$ 23/2001, também tramitava outra proposta que viria a se tornar a Emenda Constitucional n. ${ }^{\circ} 32$, de 11 de setembro de 2001. Esta Emenda, dentre outras alterações, determinou ser competência privativa do Presidente da República a iniciativa do processo legislativo para dispor sobre a criação de órgãos da Administração Pública (artigo 61, § $1^{\text {o }}$, inciso II, alínea "e"). ${ }^{190}$

${ }^{189}$ PRESIDÊNCIA DA REPÚBLICA. Mensagem n ${ }^{\circ} 1.213$, de 31 de outubro de 2001. Disponível em: <http://www.planalto.gov.br/ccivil_03/leis/Mensagem_Veto/2001/Mv1213-01.htm>. Acesso em: 27 nov. 2011.

${ }^{190}$ Art. 61. A iniciativa das leis complementares e ordinárias cabe a qualquer membro ou Comissão da Câmara dos Deputados, do Senado Federal ou do Congresso Nacional, ao Presidente da República, ao Supremo Tribunal Federal, aos Tribunais Superiores, ao Procurador-Geral da República e aos cidadãos, na 
No que tange à alteração do artigo $6^{\circ}$, trata-se também de competência privativa do Presidente da República a iniciativa do processo legislativo para dispor sobre servidores públicos, regime jurídico e provimento de cargos (artigo 61, § $1^{\text {o }}$, inciso II, alínea "c"). ${ }^{191}$

Com isso, caso o Projeto de Lei fosse sancionado pelo Presidente e consequentemente publicado no Diário Oficial, teríamos inserido em nosso ordenamento jurídico dispositivo eivado de vício, visto que o processo legislativo que lhe deu origem não cumpriu com os ditames inovados pela $\mathrm{EC} \mathrm{n} .^{0} 32 / 2001$.

Entretanto, por acreditar que os dispositivos que haviam sido vetados traziam consigo norma importante para o mercado de capitais brasileiro, o então Ministro da Fazenda, Pedro Sampaio Malan, enviou ao Presidente proposta de edição de Medida Provisória para promover estas alterações na Lei n. ${ }^{\circ} 6.385 / 1976 .{ }^{192}$

Cabe aqui abrir um parêntese explicativo: como se sabe, a Medida Provisória está prevista no artigo 62, da Constituição Federal. ${ }^{193}$ Trata-se de ato de competência do Presidente da República, ao qual se atribui força de lei em face da previsão expressa na Carta Magna. ${ }^{194}$

Quanto aos aspectos formais, determina o mesmo dispositivo que a medida provisória poderá ser adotada apenas nos casos de relevância e urgência. Ao tratar do tema, Marco Aurélio Greco ${ }^{195}$ aponta que a Constituição Federal não faz menção a "necessidade", mas sim a "relevância, que é conceito distinto. E conclui que 'relevância'

forma e nos casos previstos nesta Constituição.

$\S 1^{\circ}$ - São de iniciativa privativa do Presidente da República as leis que:

(...)

II - disponham sobre:

(...)

e) criação e extinção de Ministérios e órgãos da administração pública, observado o disposto no art. 84, VI (Redação dada pela Emenda Constitucional n ${ }^{\circ} 32$, de 2001).

${ }^{191}$ Art. 61. A iniciativa das leis complementares e ordinárias cabe a qualquer membro ou Comissão da Câmara dos Deputados, do Senado Federal ou do Congresso Nacional, ao Presidente da República, ao Supremo Tribunal Federal, aos Tribunais Superiores, ao Procurador-Geral da República e aos cidadãos, na forma e nos casos previstos nesta Constituição.

$\S 1^{\circ}$ - São de iniciativa privativa do Presidente da República as leis que:

(...)

II - disponham sobre:

(...)

c) servidores públicos da União e Territórios, seu regime jurídico, provimento de cargos, estabilidade e aposentadoria; (Redação dada pela Emenda Constitucional no 18, de 1998).

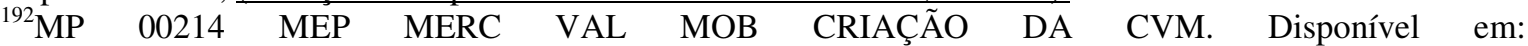
<http://www.planalto.gov.br/ccivil_03/Exm/2001/exm-214-mpv-08.pdf>. Acesso em: 16 set. 2011.

${ }^{193}$ Art. 62. Em caso de relevância e urgência, o Presidente da República poderá adotar medidas provisórias, com força de lei, devendo submetê-las de imediato ao Congresso Nacional. (Redação dada pela Emenda Constitucional $\mathrm{n}^{\circ}$ 32, de 2001).

${ }^{194}$ GRECO, Marco Aurélio. Medidas provisórias. São Paulo: Ed. Revista dos Tribunais 1991. p. 16.

${ }^{195}$ Id. Ibid., p. 22-24. 
constitucionalmente contemplada é aquela que demanda a edição de uma norma de nível legal, e não uma 'relevância' de menor grau”.

Já quanto à urgência, refere que "não existe urgência se a eficácia da disposição veiculada pela medida provisória só puder se materializar após um lapso temporal suficientemente amplo que permitiria a tramitação normal do processo legislativo, em algumas das formas disciplinadas pela Constituição". Dá como exemplo para a ausência do requisito da urgência, a introdução de modificação na legislação tributária no mês de maio, cuja eficácia somente ocorrerá no primeiro dia do ano subsequente. ${ }^{196}$

Por fim, conclui salientando a necessidade de motivação expressa como requisito para a edição de medida provisória: "a verificação destes dois requisitos e os elementos que permitirão a sua análise devem encontrar-se, como mencionei, na motivação expressa que deve acompanhar a edição da medida provisória. Motivação cuja falta vicia a medida provisória editada."197

Pois bem. Observando os requisitos formais acima apontados, a exposição de motivos para a edição da Medida Provisória sob comento justifica sua relevância alegando a "inadiável necessidade de modernizar o órgão regulador do mercado de
capitais, como medida de incentivo ao desenvolvimento da economia
nacional." Quanto à urgência da medida, afirma que "o adiamento dessas
medidas poderá ocasionar graves prejuízos à economia nacional pela
redução do aporte de recursos para as empresas nacionais, provocada
pelas incertezas decorrentes dos referidos vetos (...)".

Em 26 de fevereiro de 2002, após o processo legislativo competente, foi publicada a Lei n. ${ }^{\circ}$ 10.411, fruto da conversão da Medida Provisória n. ${ }^{\circ}$ 8. Com isso, a CVM foi legalmente classificada como uma autarquia sob regime especial, e passou a ser dotada de maior autonomia administrativa e financeira, conforme agora veremos.

Atualmente a Comissão de Valores Mobiliários é uma autarquia sob regime especial com patrimônio próprio, ausência de subordinação hierárquica, dotada de autonomia financeira e orçamentária, bem como de autoridade administrativa independente.

Ademais, a Lei n. ${ }^{\circ}$ 10.411/2002 promoveu outra mudança de fundamental relevância no texto original da Lei n. ${ }^{\circ}$ 6.385/1976. Quando da criação da CVM, sua

\footnotetext{
${ }^{196}$ GRECO, Marco Aurélio. op. cit., p. 24.

${ }^{197}$ Id. Ibid., p. 25.
} 
administração se dava por meio de um presidente e quatro diretores que, entretanto, eram demissíveis ad nutum. Contudo, com a referida alteração do artigo $6^{\circ}$, os mandatos dos dirigentes passaram a ser fixos, sem possibilidade de tal forma de demissão.

Note-se que esta alteração promovida no artigo $6^{\circ}$ teve o cuidado de atribuir-lhe redação com estrita observância das condições presentes nas disposições da já mencionada Lei n. ${ }^{\circ}$ 9.986/2000, que tratam da gestão de recursos humanos das agências reguladoras.

Vê-se, com isso, que a Lei n. ${ }^{\circ}$ 10.411/2002 conferiu à CVM as características atribuídas às agências reguladoras brasileiras. Tais alterações, conforme noticia Luís Roberto Barroso ${ }^{198}$, empregaram à Comissão de Valores Mobiliários status de agência reguladora, haja vista suas características de independência ${ }^{199}$ e maior grau de autonomia. $^{200}$

Quanto à denominação, ao contrário das demais agências, a CVM não carrega em seu nome a alcunha de agência. Entretanto, trata-se de fato que, por si só, não é suficiente para destituí-la desta designação, como adverte Celso Antônio Bandeira de Mello: ${ }^{201}$

\begin{abstract}
Anote-se, derradeiramente, que há uma entidade cujas funções são de índole equivalente às das "agências reguladoras" e à qual também veio a ser atribuído o qualificativo de autarquia "sob regime especial", mas que não recebeu a designação de "agência", pois foi mantido seu nome original: Comissão de Valores Mobiliários - CVM.
\end{abstract}

Não obstante a designação (ou ausência de) de agência reguladora, o que de fato há é uma entidade dotada de personalidade jurídica de direito público, criada por lei própria com a específica finalidade de disciplinar o mercado de capitais. Ou seja, em linhas gerais, segue o exemplo das características conferidas aos demais órgãos reguladores.

Falamos em linhas gerais por dois motivos: o primeiro, porque como já visto anteriormente, não há uma definição legal sobre o que seria uma agência reguladora no sistema jurídico brasileiro. O que existe, na realidade, são leis instituidoras destas autarquias especiais, a elas conferindo, em regra, maior autonomia. Por conseguinte, no

\footnotetext{
${ }^{198}$ BARROSO, Luís Roberto. Agências reguladoras: Constituição, transformação do Estado e legitimidade democrática. In: BINENBOJM, Gustavo (Coord.). Agências reguladoras e democracia, cit., p. 69.

${ }^{199}$ Bernstein fixa os parâmetros para que haja esta independência: “'Independence' relates to one or more of the following conditions: location outside an executive department; some measure of independence from supervision by the president or by a Cabinet secretary; immunity from the president's discretionary power to remove members of independent commissions from office." BERNSTEIN, Marver H. op. cit.

${ }^{200}$ Compartilhando deste entendimento: JUSTEN FILHO, Marçal. op. cit., p. 336-337.

${ }^{201}$ MELLO, Celso Antônio Bandeira de. op. cit., p. 158.
} 
que se refere à autonomia administrativa, notadamente à impossibilidade de revisão das decisões proferidas pela Comissão de Valores Mobiliários, importante tecer alguns comentários.

\title{
2.2.4.1. A Comissão de Valores Mobiliários e o Conselho de Recursos do Sistema Financeiro Nacional: o problema da ausência de caráter final das decisões proferidas pela Comissão de Valores Mobiliários
}

Uma das funções legalmente imputadas à Comissão de Valores Mobiliários, conforme a seguir veremos, é a função julgadora. Ou seja: a ela compete dirimir conflitos oriundos do mercado de capitais brasileiro. Ademais, dispõe o artigo 11, da Lei n. ${ }^{\circ}$ 6.385/1976, que poderá a CVM impor penalidades aos infratores de normas cujo cumprimento compita a ela fiscalizar.

Entretanto, na sequência do artigo 11, a redação do $\S 4^{\circ}$ determina o seguinte:

\begin{abstract}
$4^{\circ}$ As penalidades somente serão impostas com observância do procedimento previsto no $\S 2^{\circ}$ do art. $9^{\circ}$ desta Lei, cabendo recurso para o Conselho de Recursos do Sistema Financeiro Nacional. (Redação dada pela Lei $n^{\circ}$ 9.457, de 5.5.1997).
\end{abstract}

Percebemos, da leitura do dispositivo acima colacionado, que da decisão da Comissão de Valores Mobiliários caberá recurso ao Conselho de Recursos do Sistema Financeiro Nacional, nos termos na lei previstos. Ou seja, as decisões prolatadas pela CVM estarão sujeitas a revisão não apenas do Poder Judiciário ${ }^{202}$, como também do próprio Poder Executivo.

O Conselho de Recursos do Sistema Financeiro Nacional, vulgarmente chamado de "Conselhinho", foi criado em 15 de março de 1985 por meio do Decreto n. ${ }^{\circ}$ 91.152. Em linhas gerais, a ele foi transferida a competência, antes detida pelo Conselho Monetário Nacional, para julgar, em segunda e última instância na esfera administrativa, recursos oriundos de decisões da CVM e do Banco Central.

\footnotetext{
${ }^{202}$ Conforme determina o inciso XXXV do artigo $5^{\circ}$, da Constituição Federal:

Art. $5^{\circ}$ Todos são iguais perante a lei, sem distinção de qualquer natureza, garantindo-se aos brasileiros e aos estrangeiros residentes no País a inviolabilidade do direito à vida, à liberdade, à igualdade, à segurança e à propriedade, nos termos seguintes:

(...)

XXXV - a lei não excluirá da apreciação do Poder Judiciário lesão ou ameaça a direito;
} 
Quanto à sua composição, assim dispõe o artigo $4^{\circ}$, do Decreto n. ${ }^{\circ}$ 91.152/1985:

Art. $2^{\circ}$ - O Conselho de Recursos do Sistema Financeiro Nacional será integrado por oito Conselheiros, de reconhecida competência e possuidores de conhecimentos especializados em assuntos relativos aos mercados financeiro e de capitais, observada a seguinte composição:

I - um representante do Ministério da Fazenda;

II - um representante do Banco Central do Brasil;

III - um representante do Banco Nacional da Habitação;

IV - um representante da Comissão de Valores Mobiliários; e

$\mathrm{V}$ - quatro representantes das entidades de classe dos mercados financeiro e de capitais, por estas indicados em lista tríplice, por solicitação do Ministro da Fazenda.

Trata-se, portanto, de órgão composto por membros especializados na matéria afeta à competência do Conselhinho. Comparando as entidades, manifestam-se Eizirik, Gaal, Parente e Henriques ${ }^{203}$, no sentido de que, em que pese à composição técnica e paritária do Conselhinho,

o exame da gravidade das penas pode ser realizado com maior conhecimento de causa pela CVM do que pelo CRSFN, uma vez que tal autarquia constitui o órgão estatal especializado para a regulação do mercado de capitais, apto, portanto, a realizar um exame mais acurado das eventuais consequências negativas de determinada conduta e da adequação da medida punitiva cabível.

Enquanto a CVM é especializada apenas no mercado de capitais, o Conselhinho, além dessa matéria, também julga questões pertinentes ao mercado financeiro.

Verificamos, com isso, que há o afastamento do caráter final das decisões proferidas pela CVM, que se tornam passíveis de apreciação por outro órgão do Poder Público. No que se refere à ausência de caráter final das decisões proferidas pela CVM, frente às características das agências reguladoras, temos, de fato, uma redução na autonomia das decisões técnicas da Comissão.

Em face desta possibilidade de revisão das decisões proferidas pela CVM por outro órgão do Poder Executivo, estaria ela impedida de assumir o papel de agência reguladora

\footnotetext{
${ }^{203}$ EIZIRIK, Nelson; GAAL, Ariadna B.; PARENTE, Flávia; HENRIQUES, Marcus de Freitas. op. cit., p. 369.
} 
do mercado de capitais? Para Alexandre Santos de Aragão ${ }^{204}$, não obstante as mudanças trazidas pela Lei . $^{\circ} 10.411 / 2002$, a resposta é positiva:

A nosso ver, contudo, este importante reforço da autonomia orgânica da CVM não foi suficiente para transformá-la em agência reguladora independente, uma vez que a sua autonomia funcional continua comprometida pelo fato de contra as suas decisões sancionatórias permanecer cabível recurso administrativo externo para o Conselho de Recursos do Sistema Financeiro Nacional (...).

Há, de fato, a redução da autonomia da Comissão de Valores Mobiliários no que se refere às decisões por ela proferidas. Entretanto, conforme bem lembra Celso Antônio Bandeira de Mello ${ }^{205}$, a autonomia das autarquias especiais está ligada a uma questão de intensidade:

\begin{abstract}
Ora, "independência administrativa" ou "autonomia administrativa", "autonomia financeira", "autonomia funcional" e "patrimonial e da gestão de recursos humanos" ou de quaisquer outros que lhe pertençam, "autonomia nas suas decisões técnicas", "ausência de subordinação hierárquica", são elementos intrínsecos à natureza de toda e qualquer autarquia, nada acrescentando ao que lhes é inerente. Nisto, pois, não há peculiaridade alguma; o que pode ocorrer é um grau mais ou menos intenso destes caracteres. (grifo do autor).
\end{abstract}

Nessa linha, também já dizia Ruy Cirne Lima, que a descentralização completa, ou seja, atribuição de independência a órgãos que não pertencem à administração direta, requer que os conteúdos dos atos do agente oriundo da descentralização sejam por ele mesmo fixados e tampouco sejam revogáveis pelo Estado ou Administração Central. No entanto, conforme advertia o mestre gaúcho, ainda que estas características sejam as que usualmente ocorrem, não possuem caráter absoluto. ${ }^{206}$

Portanto, poderíamos concluir que há, no caso, apenas uma diminuição na intensidade da autonomia da CVM. Isso porque a Comissão não perde seu caráter de autarquia especial, dotada de maior autonomia em relação à Administração Direta, bem como a garantia da estabilidade de seus dirigentes, que não poderão ser exonerados ad nutum.

\footnotetext{
${ }^{204}$ ARAGÃO, Alexandre Santos de. op. cit., p. 303-304.

${ }^{205}$ MELLO, Celso Antônio Bandeira de. op. cit., p. 160.

${ }^{206}$ LIMA, Ruy Cirne. Princípios de direito administrativo. 5. ed. São Paulo: Ed. Revista dos Tribunais, 1982. p. 147.
} 
Ademais, ao alertar que, dependendo do arranjo legal, as agências reguladoras terão um maior ou menor grau de autonomia, Dinorá Adelaide Musetti Grotti ${ }^{207}$ conclui que "o Poder Executivo não tem a faculdade de mudar as decisões concretas, nem as normas editadas pela agência. Seus atos não podem ser revistos ou alterados pelo Poder Executivo, salvo se houver expressa previsão legal para a admissão do recurso hierárquico impróprio ${ }^{208}$." (grifo nosso).

Conforme acima colacionado, há dispositivo na Lei do Mercado de Capitais prevendo, expressamente, a possibilidade de interposição de recurso ao Conselho de Recursos do Sistema Financeiro Nacional, de decisões proferidas pela CVM. Em nosso entender, todavia, tal revisão não possui o condão de anular, por si só, o seu poder normativo, nem tampouco de retirar-lhe o status de agência reguladora.

Parece-nos que a discussão acerca da autonomia usualmente serve-se de argumentos que passam ao largo do que realmente importa sobre o tema. A autonomia das agências tem a função precípua de evitar sua captura pelo governo, ou, mais precisamente, por quem está governando em determinado momento. A autonomia, portanto, serve para blindar a agência da influência política do chefe do executivo e seus ministros, e, como sói ocorrer, do partido político ao qual eles pertencem, evitando assim o direcionamento político-partidário na atuação do órgão.

Ora, a revisão das decisões da CVM pelo CRSFN não acarreta necessariamente tal contaminação política, pois este último também é um órgão cujos membros são nomeados por critérios técnicos e tem sua composição paritária ${ }^{209}$, i.e., metade dos integrantes advém

\footnotetext{
${ }^{207}$ GROTTI, Dinorá Adelaide Musetti. As agências reguladoras. Revista Eletrônica de Direito Administrativo Econômico, Salvador, Instituto de Direito Público da Bahia, n. 6, maio/jul. 2006. Disponível em: $<$ http://www.direitodoestado.com.br>. Acesso em: 12 dez. 2011.

${ }^{208} \mathrm{O}$ recurso hierárquico, previsto no $\S 1^{\mathrm{o}}$, do artigo 56, da Lei n. ${ }^{\circ}$ 9.784/1999, é a manifestação dirigida "à autoridade imediatamente superior à que proferiu a decisão questionada, postulando sua reforma ou supressão". Será próprio quando dirigido e apreciado por autoridade superior no mesmo órgão administrativo, e impróprio quando dirigido e apreciado por autoridade ou órgão distinto daquele que proferiu a decisão recorrida. MELLO, Celso Antônio Bandeira de. op. cit., p. 136-137. Portanto, no caso da Comissão de Valores Mobiliários, o recurso encaminhado ao Conselho de Recursos do Sistema Financeiro Nacional será o recurso hierárquico impróprio.

${ }^{209}$ Importante aqui apenas pontuar que conforme o artigo 17 , do Decreto n ${ }^{\circ}$ 1.935/1996, que dispõe sobre a organização e o funcionamento do Conselho de Recursos do Sistema Financeiro Nacional, ao Presidente do Conselhinho caberá o voto de qualidade: “Art. 17. O Conselho deliberará quando presentes três quartos de seus membros, e as deliberações serão tomadas por maioria simples, cabendo ao Presidente também o voto de qualidade." Ou seja, o decreto confere ao Presidente do Conselhinho a atribuição de proferir voto de qualidade nas decisões em caso de empate na votação. Entretanto, não obstante tal previsão, por certo que o voto deverá ser técnico, assim como todos os demais. Não é pelo fato de sua indicação ser feita pelo Ministério da Fazenda e do seu voto ser de qualidade que suas decisões necessariamente deverão acompanhar os interesses, seja lá quais forem, do governo, pois sua atuação como julgador deve ser obviamente independente.
} 
de órgãos públicos (Ministério da Fazenda, Banco Central do Brasil, Banco Nacional da Habitação e Comissão de Valores Mobiliários), enquanto a metade restante é composta por representantes de entidades de classe do mercado financeira e de capitais. Ainda que seus membros sejam designados pelo Ministro da Fazenda, a escolha dos candidatos é realizada pelas entidades governamentais acima listadas e de classe (esta em lista tríplice), cabendo ao Ministro apenas decidir quais candidatos de setor privado irá nomear. Sendo assim, a possibilidade de influência política direta do governo sobre o órgão diminui consideravelmente.

Apenas a título de exemplo, acerca do reconhecimento do Poder Legislativo em relação ao status de agência reguladora da CVM, cumpre-nos destacar o artigo 10-A, da Lei n. ${ }^{o}$ 6.385/1976, que a classifica como agência reguladora:

Art. 10-A. A Comissão de Valores Mobiliários, o Banco Central do Brasil e demais órgãos e agências reguladoras poderão celebrar convênio com entidade que tenha por objeto o estudo e a divulgação de princípios, normas e padrões de contabilidade e de auditoria, podendo, no exercício de suas atribuições regulamentares, adotar, no todo ou em parte, os pronunciamentos e demais orientações técnicas emitidas. (Incluído pela Lei $n^{\circ} 11.638$, de 2007)

Uma vez apresentadas as principais discussões acerca das agências reguladoras no direito brasileiro, bem como estabelecidos os contornos da Comissão de Valores Mobiliários, passaremos a verificar qual o limite para o exercício de seu poder normativo. 


\section{O PODER NORMATIVO DA COMISSÃO DE VALORES MOBILIÁRIOS}

Conforme discorrido em capítulos anteriores, a Comissão de Valores Mobiliários constitui órgão estatal responsável pela regulação do mercado de capitais brasileiro. A regulação deste mercado se dá por meio de normas jurídicas, que à CVM compete criar ou aplicar, de forma a ordenar a conduta dos agentes que compõem este núcleo específico de atuação.

Entretanto, há limites à competência da CVM como órgão emissor de normas jurídicas, sendo este o assunto que a seguir pretendemos tratar.

\subsection{Poder e competência: a criação de normas jurídicas}

O vocábulo "competência" possui diversas acepções, a depender do contexto onde se encontra inserido. Comumente nos deparamos com o emprego do vocábulo para qualificar a capacidade de determinado indivíduo para realizar algo de modo satisfatório. Ou seja, sua utilização ligada à ideia de habilidade, de know how, de fazer bem algo.

Já ao pensarmos em competência no seu sentido jurídico, nos deparamos com a ideia de determinado ente ter a capacidade, aqui no sentido de poder e não de habilidade, para realizar algo. Nas palavras de Celso Antônio Bandeira de Mello ${ }^{210}$, competências “são deveres-poderes, expressão, esta, que descreve melhor suas naturezas do que a expressão poder-dever, que começou a ser utilizada, algumas vezes, no Direito Administrativo, a partir de lições de Santi Romano.” (grifo do autor).

O ilustre autor faz esta referência por entender que o fato de o Estado possuir capacidade para realizar determinada tarefa, não a torna opcional. Isto é, tal tarefa, uma vez atribuída ao Estado, faz com que ele, Estado, seja obrigado a realizá-la. Por isso, estaríamos diante de dever-poder. Ademais, se a lei determina que eu devo fazer algo significa que também posso fazer este algo, e não o contrário.

${ }^{210}$ MELLO, Celso Antônio Bandeira de. op. cit., p. 132. 
Neste sentido, cumpre apontar que, em termos lógico-deônticos, o "dever" não decorre do "poder" fazer algo, mas sim, o contrário. De forma a ilustrar a relação lógica entre os chamados modais deônticos, apresentamos o quadrado lógico de oposições deônticas, conforme figura abaixo:

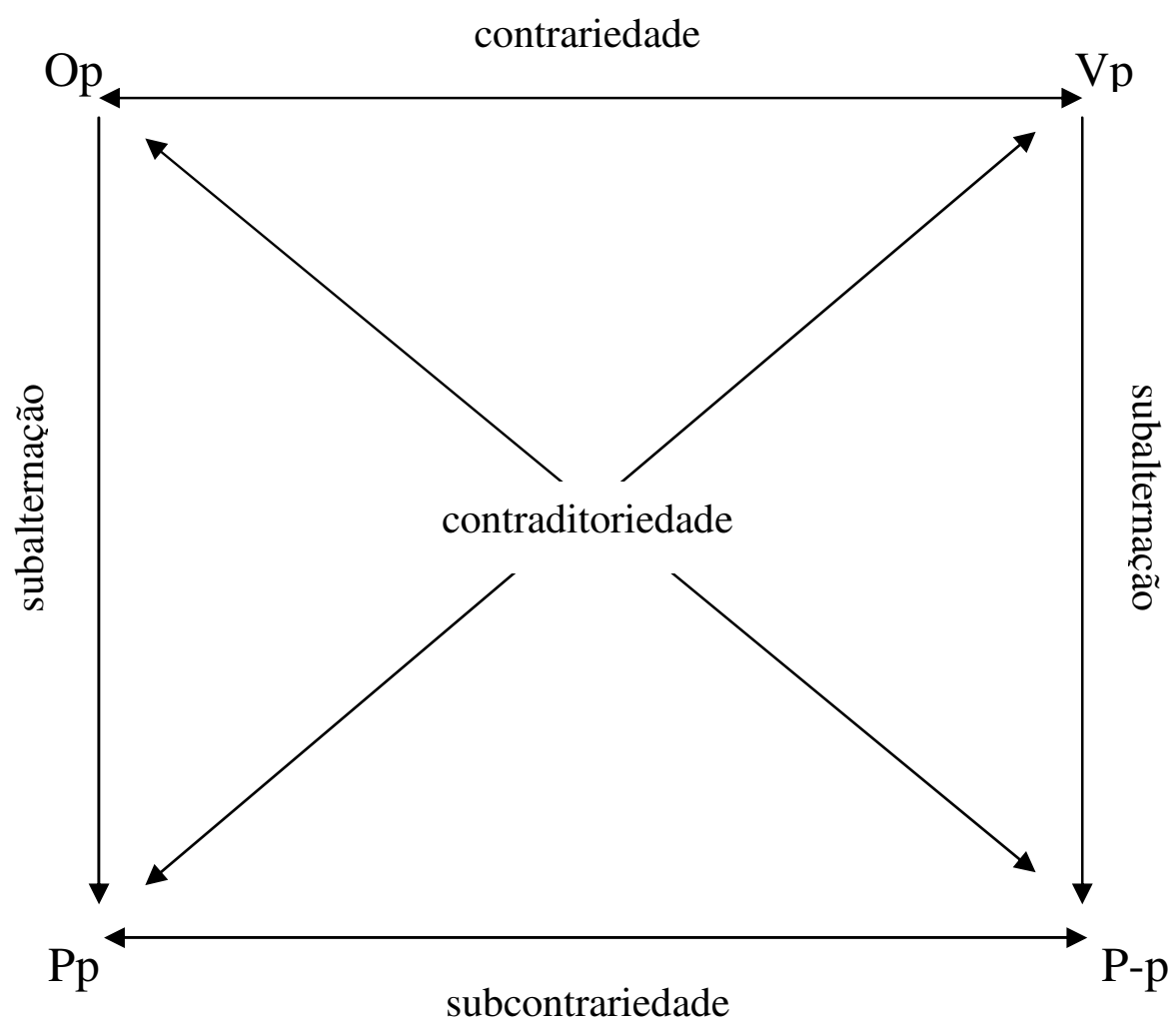

Os modais $\mathrm{V}$, O e $\mathrm{P}$, respectivamente proibição, obrigação e permissão, seguidos de "p", que é o predicado lógico que se refere à conduta, inter-relacionam-se e são interdefiníveis. Por exemplo: ser obrigado a fazer algo equivale a ser proibido de não fazer esse algo, ou ser permitido a fazer algo significa não ser proibido de fazer esse algo. Observando o quadrado, percebe-se que do poder fazer ou do poder não fazer (Pp e P-p), cuja combinatória permissiva leva à ideia de faculdade, não decorrem nem a obrigação, nem a proibição.

Em outras palavras, do poder não decorre o dever, mas sim o oposto: apenas do dever (Op) decorre a permissão (Pp) de fazer algo. Se somos obrigados a fazer algo, necessariamente somos permitidos a fazer esse algo (relação de subalternação); todavia, se somos permitidos a fazer algo, não significa que sejamos obrigados a fazê-lo. ${ }^{211}$

${ }^{211}$ Conforme Paulo de Barros Carvalho: "Adviria daí o 'dever-poder' do agente, ao realizar o lançamento, para aqueles que priorizam o aspecto interno (Fazenda-funcionário); e o 'poder-dever' da Administração 
Por conseguinte, competência jurídica na Administração Pública significa um dever e um poder fazer algo. Mas ainda, enquanto poder jurídico, “competência pode ser entendida, especificamente, como capacidade juridicamente estabelecida de criar normas jurídicas (ou efeitos jurídicos) por meio e de acordo com certos enunciados."212 E é neste sentido que aqui utilizamos o vocábulo. Isto é, competência normativa como sinônimo de dever-poder normativo.

Entretanto, ao pensarmos em poder normativo, podemos muitas vezes incorrer na ideia de compreendê-lo como aquele que confere competência apenas para emissão de normas abstratas e gerais. Ou seja, como aquele que atribui a determinado órgão a capacidade para editar diplomas tais como instruções. Esta, inclusive, é a comumente denominada "função normativa" da Comissão de Valores Mobiliários, qual seja, sua prerrogativa de editar comandos gerais que visam coordenar o mercado.

Todavia, não é esta visão restritiva de poder normativo que adotamos no presente trabalho.

Por poder normativo, entendemos a competência da CVM para editar normas, sejam elas concretas, abstratas, individuais ou gerais. Nesta compreensão, é o poder normativo que a ela confere competência para, por exemplo, editar instruções, conceder registros, bem como, por meio da aplicação da norma ao caso concreto, julgar.

Portanto, conforme a seguir veremos, o exercício pela Comissão de algumas de suas principais funções, envolve a ponência de normas no ordenamento.

\footnotetext{
para atuar o lançamento, com ênfase na competência a ser exercida perante o administrado (Fazenda contribuinte). Ambas as locuções ('dever-poder' e 'poder-dever'), entretanto, não resistem a uma análise mais paciente. Sob o ponto de vista lógico, todo dever implica um poder: $(\mathrm{Op} \rightarrow \mathrm{Pp})$, que se pode interpretar: se uma conduta "p" é obrigatória, então está permitido cumpri-la. Seja como for, retendo-se a conduta obrigatória, sua permissibilidade estará necessariamente implícita, sendo redundante a construção. Por outro lado $(\mathrm{Pp} \rightarrow \mathrm{Op})$, querendo afirmar que, se uma conduta " $\mathrm{p}$ " é permitida, então ela é obrigatória, não se sustenta, uma vez que da permissão não se extrai a obrigação. Se tentarmos outro trajeto para imaginar o "poder-dever", chegaremos igualmente a soluções absurdas: (Pp.Op) significaria uma conduta "p", simultaneamente, permitida e obrigatória. Como em toda obrigação está embutida uma permissão, bastaria registrar a conduta obrigatória ("Op"), sendo despicienda a referência à permissão ("Pp"). Não encontrando fundamentação lógica, as expressões supracitadas justificar-se-iam no plano semântico e pragmático. Todavia, não será esse o melhor caminho na construção de uma linguagem científica, que se quer forte nas instâncias sintática e semântica, para ter a potência de descrever o objeto que se propõe, com o máximo rigor possível." CARVALHO, Paulo de Barros. Curso de direito tributário. 14. ed. São Paulo: Saraiva, 2002. p. 370-371.

${ }^{212}$ FERRAZ JUNIOR, Tercio Sampaio. Competência tributária municipal. Revista de Direito Tributário, São Paulo, ano 14, n. 54, p. 158, out./dez. 1990.
} 


\subsection{Categorias normativas e a Comissão de Valores Mobiliários}

Ao lermos detidamente a Lei n. ${ }^{\circ}$ 6.385/1976, observamos que há menções acerca do poder normativo da Comissão de Valores Mobiliários ao longo de seu texto. Algumas vezes nos deparamos com a sua competência para emitir normas abstratas e gerais, outras vezes normas concretas e individuais, ou ainda normas concretas e gerais e abstratas e individuais.

Isso porque normas não são somente aquelas constantes em determinada lei ou regramento. Normas também estão presentes, por exemplo, na sentença prolatada pelo juiz e no contrato firmado entre duas partes, conforme a seguir discorreremos.

\subsubsection{Normas: princípios e regras}

Importante neste momento, antes de seguirmos adiante, estabelecer o que entendemos por norma jurídica. Ao tratarmos de normas, estamos diante de um gênero que comporta duas espécies: os princípios e as regras. Trata-se de classificação que busca propor um modelo com potencial explicativo da realidade normativa.

Esta classificação dispõe que todos os enunciados prescritivos, i.e., elementos do ordenamento, podem ser denominados de norma. ${ }^{213}$ Entretanto, não obstante estarem classificados dentro de um mesmo grupo, ressaltamos que há diferenças importantes entre princípios e regras, conforme a seguir veremos.

\subsubsection{Diferenças entre princípios e regras}

Muitas são as diferenças que podemos identificar entre os princípios e as regras. Podemos diferenciá-los, e.g., no tocante à objetividade da norma, quanto à sua estrutura normativa, bem como em razão da sua função dentro do ordenamento.

${ }^{213}$ GRAU, Eros Roberto. Ensaio e discurso sobre a interpretação/aplicação do direito. São Paulo: Malheiros Ed., 2002. p. 39. 
Quando falamos em objetividade da norma jurídica, nos referimos à dose de esforço que será empregada em sua interpretação. Ou seja, com que facilidade compreenderemos o texto normativo. Neste primeiro aspecto, a diferença reside na maior objetividade de uma regra jurídica frente ao princípio. As regras são objetivas, ou, pelo menos, buscam ser - são o "tudo ou nada", na famosa frase de Ronald Dworkin. ${ }^{214}$ Já princípios possuem maior carga subjetiva, pois se referem a fins que nem sempre são plenamente atendidos, e sua observância se dá na medida em que suas finalidades são passíveis de cumprimento.

Entretanto, importante frisar que, se de um lado a objetividade da regra facilita a sua aplicação, poupando o operador do direito do custo que a indeterminação dos princípios acarreta, por outro lado, essa mesma objetividade gera limites para o atendimento de seus valores subjacentes. Já os princípios, com sua subjetividade, abrem espaço para a argumentação jurídica que muitas vezes opera como instrumento útil para a calibração do sistema, notadamente em solução de casos difíceis.

Quanto à estrutura normativa, as regras possuem uma formulação implicacional, onde se $p$ então $q$. Exemplifica-se: se algum indivíduo que tenha conhecimento de alguma informação relevante ainda não divulgada ao mercado e sobre a qual deva manter sigilo, a utiliza de forma a propiciar, para si ou para outrem, vantagem indevida, mediante negociação, em nome próprio ou de terceiro, com valores mobiliários (hipótese), sofrerá reclusão e imposição de multa em decorrência do ilícito cometido (consequente). ${ }^{215}$

Já os princípios não possuem estrutura lógico-condicional, manifestando-se por meio de comandos prima facie que informam valores a serem seguidos na construção do ordenamento. Como não há uma hipótese de incidência factual definida, princípios são comandos estruturalmente mais simples que as regras.

No que se refere à função, toda norma jurídica possui a função de prescrever comportamentos humanos. De um lado, as regras têm a função precípua de coordenar, objetivamente, as ações dos indivíduos, sejam elas regras morais, éticas, sociais ou jurídicas.

\footnotetext{
${ }^{214}$ DWORKIN, Ronald. Taking rights seriously. 16. ed. Cambridge: Harvard University Press, 1997. p. 24.

${ }^{215}$ Artigo 27-D da Lei n. ${ }^{\circ} 6.385$ de 1976.
} 
A função dos princípios, de forma diversa, é operar como vetor na construção do sistema. São os princípios, portanto, normas endógenas. ${ }^{216}$ Isso porque enquanto as regras têm a função de objetivamente determinar condutas, modalizando-as em proibidas, obrigatórias e permitidas $^{217}$, com o fím de alcançar ou preservar valores tidos como desejáveis socialmente, os princípios são normas com alta carga axiológica, i.e., valores morais que tornam-se jurídicos após a sua devida conversão normativa pelo legislador.

Pensemos, analogicamente, apenas a título ilustrativo, em uma consulta médica. Após sermos avaliados pelo médico, bem como realizarmos a bateria de exames por ele determinada, nos é dado o diagnóstico: devemos levar uma vida mais saudável. Uma vida mais saudável. Mas o que exatamente quer o médico dizer com isso? O que, objetivamente, devemos fazer para conseguirmos cumprir com a determinação médica?

Questionamos, portanto, o médico. Como resposta, surgem uma série de recomendações que deverão ser diariamente por nós observadas, tais como: prática de 30 minutos de exercício aeróbico, ingestão de 3 frutas, inclusão de salada no cardápio, etc. Entretanto, não apenas ações (obrigatoriedades) serão de nós exigidas. Determinará o médico que não poderemos, por exemplo, ingerir bebida alcoólica, fumar cigarro ou charuto ou comer gorduras. Serão estas imposições que nos impedirão (proibições) de realizar determinadas tarefas. Por fim, enumerará o médico uma série de prescrições, em relação às quais seremos livres (permissões) para optar se as observaremos ou não, tal como a possibilidade de comermos um chocolate por dia.

Seguindo na ilustração acima apresentada, podemos pensar no predicado “saudável” como um princípio (jurídico) disposto pelo médico (legislador). Há, certamente, um senso comum sobre o que seria viver de forma saudável. Entretanto, apenas a imprecisão do senso comum, não mais que isso. É neste contexto que as determinações médicas, objetivamente a nós prescritas (regras jurídicas), nos permitirão cumprir com as imposições, de acordo com o que o próprio médico (novamente o legislador) compreende por "saudável”. Para isso, serão a nós conferidas uma série de recomendações (regras jurídicas proibindo, permitindo e obrigando).

\footnotetext{
${ }^{216}$ CARVALHO, Cristiano. Teoria da decisão tributária. 2010. Tese (Livre-Docência) - Faculdade de Direito, Universidade de São Paulo, São Paulo, 2010. p. 339.

${ }^{217}$ VILANOVA, Lourival. Estruturas lógicas e o sistema de direito positivo. 3. ed. São Paulo, 2005. p. 76.
} 
Nesse diapasão, Robert Alexy ${ }^{218}$ diferencia os princípios das regras, por serem estas comandos definitivos, e aqueles, mandamentos de otimização. Ou seja, as regras, ao serem cumpridas, esgotam-se, cumprem sua função. Os princípios, por outro lado, podem ser atendidos (ou otimizados) em diferentes graus, mas nunca se esgotam. No exemplo acima, uma pessoa nunca satisfará totalmente o objetivo de ser saudável, pois trata-se de fim que pode até ser alcançado, porém requer a sua manutenção constante, que se efetivará por meio das práticas objetivas recomendadas pelo médico.

Diante disso, nos parece claro que pretender operar apenas, ou preponderantemente, com princípios, em detrimento de regras, para resolver casos concretos, não só é uma impossibilidade - uma vez que não há determinação da conduta a ser tomada - como também uma opção temerária para a própria segurança jurídica. Em última instância, cautela no uso dos princípios atende aos próprios princípios, uma vez que evita que os mesmos se tornem vulgarizados. ${ }^{219}$

\subsubsection{Regras abstratas, gerais, concretas e individuais}

As regras jurídicas, como acima referido, são comandos diretivos de conduta. Trata-se de mandamentos que visam regular os comportamentos dos indivíduos em face do sistema jurídico, por intermédio dos modais deônticos da obrigação, proibição e permissão. $^{220}$

São as regras que efetivamente orientam condutas, pois, conforme a seguir veremos, sua estrutura implicacional e sua modalização em proibições, obrigações e permissões delineiam o substrato lógico sintático que, aliado ao plano semântico, conferem a elas a objetividade que permite a seus destinatários a compreensão do comportamento

\footnotetext{
${ }^{218}$ ALEXY, Robert. The construction of constitutional rights: law, ethics and human rights. Berkeley Electronic Press, Berkeley, v. 4, n. 1, p. 21, 2010.

${ }^{219} \mathrm{O}$ que supostamente poderia parecer algo benéfico aos cidadãos, torna-se, na verdade, um pesadelo típico de Kafka, em O processo (Trad. Modesto Carone. São Paulo: Companhia das Letras, 2005). Nesta obra, o personagem Joseph K. sabe que é acusado, porém nunca lhe é informado qual ilícito cometeu, o porquê de ser acusado, ou mesmo as consequências da acusação. Utilizar princípios em detrimento de regras remete à situação perigosamente parecida.

${ }^{220}$ Os três, e somente três, modalizadores lógicos das condutas intersubjetivas são: obrigatório, proibido e permitido. Esta modalização não denota um capricho do legislador, mas sim uma limitação da própria racionalidade humana. Trata-se da lei deôntica do quarto excluído, segundo a qual não há possibilidade de haver uma quarta modalização de condutas. Sobre o tema, ver: CARVALHO, Paulo de Barros. Direito tributário, linguagem e método, cit., p. 83. VILANOVA, Lourival. op. cit., p. 71.
} 
juridicamente esperado. Ou ainda, permite a seus destinatários uma tomada de decisão consciente diante das limitações que o Direito impõe às suas liberdades.

No que tange à estrutura lógica implicacional acima referida, as regras são formadas por um antecedente e um consequente. ${ }^{221} \mathrm{O}$ antecedente pode estipular possíveis condutas no mundo fenomênico, como também relatar acontecimentos já ocorridos. No primeiro caso, trata-se da hipótese de incidência, no último, trata-se de fato jurídico. $\mathrm{O}$ consequente, por seu turno, determina relação jurídica, que pode ter os seus sujeitos ainda indeterminados, por força do caráter hipotético da regra, como também possuir os sujeitos da relação obrigacional devidamente identificados.

Percebemos, com isso, que a estrutura da regra jurídica será sempre implicacional. Será por meio dela que um pressuposto de fato será vinculado a uma consequência.

A regra possuirá antecedente abstrato quando referir-se a acontecimento por ocorrer, ou seja, a fato hipotético. Assim, percebe-se que o antecedente abstrato possui a seguinte estrutura: se ocorrer o fato "F". Em contrapartida, a norma terá antecedente concreto quando referir-se a situação já ocorrida, devidamente prevista na regra abstrata. Com isso, sua estrutura é a seguinte: dado que ocorreu o fato "F".

Quanto ao destinatário da regra, ela será geral quando direcionada a determinado

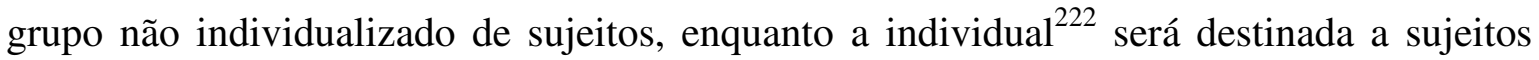
identificados.

Dito isso, percebemos que quanto a sua estrutura as regras podem ser classificadas em quatro espécies, a saber: concreta e individual; abstrata e individual; concreta e geral; abstrata e geral.

Assim sendo, por concreta e individual entende-se aquela regra que possui em seu antecedente fato já ocorrido, e em seu consequente, sujeito de direito devidamente identificado. A título de exemplo, segundo os ensinamentos de Norberto Bobbio, conforme a seguir transcrito, uma regra concreta e individual pode ser uma sentença emanada pelo juiz: "Não resta dúvida, por exemplo, de que a sentença com que o juiz condena um

\footnotetext{
${ }^{221}$ VILANOVA, Lourival. op. cit., p. 106.

${ }^{222}$ Como exemplo de regra individual, Norberto Bobbio utiliza a sentença de um tribunal que, com base em determinado dispositivo do Código Civil italiano, impõe ao cônjuge sobre o qual foi pronunciada a separação, que mantenha junto de si os filhos, provendo sua manutenção, educação e instrução. BOBBIO, Norberto. Teoria geral do direito, cit., p. 161. Neste mesmo sentido, ver: FERRAZ JUNIOR, Tercio Sampaio. Introdução ao estudo do direito: técnica, decisão e dominação. 6. ed. São Paulo: Atlas, 2008. p. 99.
} 
indivíduo a um determinado comportamento (por exemplo, ao ressarcimento de danos) é uma norma, ao mesmo tempo, individual e concreta". ${ }^{223}$

Nesta mesma esteira, quando o Colegiado da CVM, no uso de sua competência prevista no inciso VI do artigo $9^{\circ}$, da Lei do Mercado de Capitais ${ }^{224}$, decide por aplicar a pena prevista no inciso II do artigo 11 , desta mesma $1 \mathrm{ei}^{225}$, condenando a parte ao pagamento de multa, esta decisão resultará em uma regra concreta e individual.

Já a regra abstrata e individual prevê situações de possível ocorrência no seu antecedente, ao passo que em seu consequente os sujeitos da relação jurídica encontram-se perfeitamente determinados. ${ }^{226}$ Exemplo mais comum são os contratos, nos quais são celebrados direitos e deveres a serem cumpridos por sujeitos de direito formalmente especificados.

O mesmo ocorre, por exemplo, quando em observância ao artigo 10, da Lei n. ${ }^{\circ}$ 6.385/1976 $6^{227}$ a CVM firma convênios com órgãos reguladores do mercado de capitais de outros países. Estes convênios serão normas abstratas e individuais.

As regras concretas e gerais são aquelas que contêm o relato de um fato jurídico, portanto uma situação efetivamente ocorrida no mundo real, porém em seu consequente há apenas uma classe de sujeitos de direito e não pessoas físicas ou jurídicas determinadas. ${ }^{228}$ Como exemplo, leis que estabelecem indenizações para sujeitos que se enquadrarem na classe de perseguidos pelo governo militar brasileiro. A regra contém um fato concreto (a ocorrência do regime de exceção) em seu antecedente lógico, cuja implicação é a indenização de todos aqueles que se apresentem e comprovam a condição de experseguidos e atuais indenizáveis pelo Estado.

\footnotetext{
${ }^{223}$ BOBBIO, Norberto. Teoria geral do direito, cit., p. 165.

${ }^{224}$ Art. $9^{\circ}$ A Comissão de Valores Mobiliários, observado o disposto no $\S 2^{\circ}$ do art. 15, poderá: (Redação dada pelo Decreto n 3.995 , de 31.10.2001)

(...)

VI - aplicar aos autores das infrações indicadas no inciso anterior as penalidades previstas no Art. 11, sem prejuízo da responsabilidade civil ou penal.

${ }^{225}$ Art. 11. A Comissão de Valores Mobiliários poderá impor aos infratores das normas desta Lei, da lei de sociedades por ações, das suas resoluções, bem como de outras normas legais cujo cumprimento lhe incumba fiscalizar, as seguintes penalidades:

$(\ldots)$

II - multa;

${ }^{226}$ CARVALHO, Paulo de Barros. Direito tributário, linguagem e método, cit., p. 144-145.

${ }^{227}$ Art. 10. A Comissão de Valores Mobiliários poderá celebrar convênios com órgãos similares de outros países, ou com entidades internacionais, para assistência e cooperação na condução de investigações para apurar transgressões às normas atinentes ao mercado de valores mobiliários ocorridas no País e no exterior. (Redação dada pela Lei no 10.303 , de 31.10.2001).

${ }^{228}$ BOBBIO, Norberto. Teoria geral do direito, cit., p. 165.
} 
Por fim, as regras abstratas e gerais são aquelas que preveem situações de possível ocorrência no seu antecedente, ao passo que em seu consequente os sujeitos da relação jurídica encontram-se indeterminados. ${ }^{229} \mathrm{Um}$ bom exemplo seria a norma prevista no artigo 121 do Código Penal que impõe que se matar alguém (hipótese), sofrerá pena de seis a vinte anos (consequente).

Trazendo isso para o âmbito da Lei n. $^{\circ}$ 6.385/1976, o mesmo ocorre quando a Comissão, por meio de sua competência prevista no inciso I do $\S 1^{\circ}$ do artigo $22^{230}$, edita a Instrução CVM 480, que traz no item 13 do anexo 24 (que veicula o conteúdo do formulário de referência) como e quais informações sobre a remuneração dos administradores deverão ser prestadas.

Percebemos, com isso, que a classificação em regras concreta, abstrata, individual e geral demonstra que o poder normativo está presente em diversas formas de manifestação da CVM.

\subsubsection{Regras de conduta e regras de competência}

As regras também podem ser classificadas como regras de conduta e regras de competência. Regras de conduta são aquelas que se dirigem ao destinatário específico da lei no sentido de orientar sua conduta, obrigando, permitindo ou proibindo determinados comportamentos. Já as regras de competência, também chamadas de normas de competência $^{231}$, normas de estrutura ${ }^{232}$ ou regras secundárias ${ }^{233}$, são aquelas que conferem poderes aos órgãos do sistema para produzirem regras.

Portanto, regras de conduta são comandos que prescrevem condutas dos agentes de mercado, enquanto regras de competência são aquelas que regulam o próprio funcionamento do sistema jurídico, coordenando sua estruturação. Neste sentido, não é

\footnotetext{
${ }^{229}$ BOBBIO, Norberto. Teoria geral do direito, cit., p. 165.

${ }^{230}$ Art . 22. Considera-se aberta a companhia cujos valores mobiliários estejam admitidos à negociação na bolsa ou no mercado de balcão.

$\S 1^{\circ}$ Compete à Comissão de Valores Mobiliários expedir normas aplicáveis às companhias abertas sobre: (Redação dada pelo Decreto ${ }^{\circ}$ 3.995, de 31.10.2001)

I - a natureza das informações que devam divulgar e a periodicidade da divulgação; (Redação dada pelo Decreto ${ }^{\circ} 3.995$, de 31.10.2001)

${ }^{231}$ ROSS, Alf. op. cit., p. 76.

${ }^{232}$ BOBBIO, Norberto. Teoria geral do direito, cit., p. 197.

${ }^{233}$ HART, Herbert L.A. op. cit., p. 122.
} 
possível regular comportamentos dos agentes do mercado, ou seja, criar e aplicar regras de conduta, sem a necessária criação e também aplicação de regras de competência.

Dentro desta classificação, conseguimos verificar que as Leis $n .^{\circ}$ 6.385/1976 e n. ${ }^{\circ}$ 6.404/1976 apresentam uma séria de comandos normativos que não são dirigidos aos destinatários da lei, mas sim à CVM, conferindo-lhe competência para exercer seu poder normativo.

Nestes casos, o que teremos serão regras de competências destinadas à Comissão que, uma vez exercidas, poderão gerar regras de condutas. Exemplifica-se: a já mencionada regra contida no inciso VI do artigo $9^{\circ}$, da Lei do Mercado de Capitais, que dispõe que a CVM poderá aplicar as penalidades previstas no artigo 11, é uma regra de competência, ou seja, confere à Autarquia o poder para aplicar as sanções elencadas nos incisos do artigo 11. Uma vez exercida esta competência no caso concreto, i.e., uma vez aplicada a sanção, estaremos diante de uma regra de conduta que, como já visto, será concreta e individual. ${ }^{234}$

Importante ressaltar que, seja na instituição de uma lei ou de uma instrução, bem como na manifestação de uma decisão administrativa ou judicial, o correto atendimento às regras de competência é condição necessária pelos órgãos produtores de normas, incluída a CVM, sob pena de possível invalidação posterior das regras por eles expedidas.

Dito isso, concluímos que há nas Leis n. ${ }^{\circ}$ 6.385/1976 e n. ${ }^{\circ}$ 6.404/1976 dispositivos conferindo à Comissão de Valores Mobiliários competência para emitir comandos normativos com diferentes combinações, i.e., atribuindo à Autarquia autoridade para dispor sobre regras abstratas e gerais, concretas e individuais, concretas e gerais, bem como abstratas e individuais. Trata-se da função normativa da CVM em seu mais amplo sentido.

Percebemos, portanto, que nestas regras de competência localizamos um limite ao poder normativo da CVM. Isso porque serão elas as responsáveis por determinar as matérias e os procedimentos que deverão ser observados pela Comissão ao emitir regras de conduta dirigidas ao mercado, o que se dará, conforme a seguir veremos, por meio do exercício de suas principais funções.

\footnotetext{
${ }^{234}$ Como outros exemplos, salientamos o $§ 3^{\circ}$ do artigo $4^{\circ}$, da Lei n. ${ }^{\circ} 6.404 / 1976$, que dispõe que a CVM poderá classificar as companhias abertas em categorias e especificar as normas sobre companhias abertas aplicáveis a cada uma destas categorias; e o $\S 3^{\circ}$ do artigo $2^{\circ}$, da Lei n. ${ }^{\circ} 6.385 / 1976$, que confere à CVM competência para expedir normas para a execução do quanto disposto no artigo acerca dos valores mobiliários.
} 


\subsection{Funções da Comissão de Valores Mobiliários: normativa, fiscalizadora, julgadora, de registro, consultiva ou de orientação, sancionadora e de fomento}

Como já vimos, a Lei n. ${ }^{\circ}$ 6.385, de 7 de dezembro de 1976, dispõe sobre o mercado de valores mobiliários e cria a Comissão de Valores Mobiliários. É em seu Capítulo II que encontramos o tratamento dado à Comissão de Valores Mobiliários. No texto que compõe este capítulo, podemos localizar, dentre outros, dispositivos tratando da instituição e natureza jurídica $\left(\operatorname{artigo} 5^{\circ}\right.$ ), composição (artigo $6^{\circ}$ ), e competência $\left(\operatorname{artigo} 8^{\circ}\right.$ ) da Autarquia.

Quanto à instituição e natureza jurídica, já sabemos tratar-se de uma autarquia sob regime especial. No que tange à composição do Colegiado, já vimos ser composto por um Presidente e quatro Diretores, nomeados pelo Presidente da República e aprovados pelo Senado Federal, cuja perda de mandato somente ocorrerá em virtude de renúncia, de condenação judicial transitada em julgado ou de processo administrativo disciplinar.

Já no que se refere à competência do órgão, este sim aspecto fundamental para o que agora pretendemos tratar, verificam-se as seguintes hipóteses previstas nos incisos do artigo $8^{\circ}$ :

Art. $8^{\circ}$ Compete à Comissão de Valores Mobiliários:

I - regulamentar, com observância da política definida pelo Conselho Monetário Nacional, as matérias expressamente previstas nesta Lei e na lei de sociedades por ações;

II - administrar os registros instituídos por esta Lei;

III - fiscalizar permanentemente as atividades e os serviços do mercado de valores mobiliários, de que trata o Art. $1^{\circ}$, bem como a veiculação de informações relativas ao mercado, às pessoas que dele participem, e aos valores nele negociados;

IV - propor ao Conselho Monetário Nacional a eventual fixação de limites máximos de preço, comissões, emolumentos e quaisquer outras vantagens cobradas pelos intermediários do mercado;

$\mathrm{V}$ - fiscalizar e inspecionar as companhias abertas dada prioridade às que não apresentem lucro em balanço ou às que deixem de pagar o dividendo mínimo obrigatório.

Das situações elencadas, percebemos que dos incisos II ao V, estamos diante de hipóteses que ventilam as atribuições da CVM quanto a sua função de administrar os registros instituídos pela Lei n. $^{\circ}$ 6.385/1976 (inciso II), quanto ao seu papel fiscalizador 
(incisos III e V), e quanto à sua competência para propor ao Conselho Monetário Nacional a eventual fixação de limites máximos de preço, comissões, emolumentos e quaisquer outras vantagens cobradas pelos intermediários do mercado (inciso IV).

Todavia, embora o artigo $8^{\circ}$ trate das atribuições que competem à CVM, também encontramos, ao longo da Lei n. ${ }^{\circ}$ 6.385/1976, outras normas dispondo sobre estas mesmas atribuições, ou ainda trazendo outras funções que não estas, que deverão ser observadas pela Autarquia.

Da leitura da Lei do Mercado de Capitais, conforme brevemente discorreremos a seguir, podemos destacar que a CVM possui precipuamente as seguintes funções: fiscalizadora, julgadora, de registro, consultiva ou de orientação, sancionadora, de fomento e normativa.

\section{a) Função fiscalizadora:}

A função fiscalizadora da Comissão de Valores Mobiliários consiste, abreviadamente, no seu dever de assegurar o fiel cumprimento das normas jurídicas pertinentes ao mercado de capitais, e encontra-se, de forma genérica, prevista na primeira parte do inciso III do artigo $8^{\circ}$, da Lei do Mercado de Capitais. ${ }^{235}$ Tais medidas fiscalizatórias têm, portanto, como derradeiro escopo, evitar danos ao mercado de capitais de forma a proteger o interesse coletivo, i.e., de seus agentes.

Mas para que esta intervenção na esfera privada ocorra, à CVM foi atribuído poder de polícia administrativa. Trata-se da forma de a Comissão dar executoriedade às normas relacionadas ao mercado de capitais.

A exemplo disso, temos no artigo $9^{\circ}$, da Lei n. ${ }^{\circ} 6.385 / 1976$, disposição capacitando a CVM a averiguar fatos e comportamentos. ${ }^{236}$ Ademais, podemos também identificar o

\footnotetext{
${ }^{235}$ Art. $8^{\circ}$ Compete à Comissão de Valores Mobiliários:

(...)

III - fiscalizar permanentemente as atividades e os serviços do mercado de valores mobiliários, de que trata o Art. $1^{\circ}$, bem como a veiculação de informações relativas ao mercado, às pessoas que dele participem, e aos valores nele negociados;

${ }^{236}$ Dentre as atribuições fiscalizadoras da CVM inserem-se, por exemplo: (a) examinar e extrair cópias de registros contábeis, livros ou documentos, inclusive programas eletrônicos e arquivos magnéticos, ópticos ou de qualquer outra natureza, bem como papéis de trabalho de auditores independentes das companhias abertas, dos fundos e sociedades de investimento, etc. (inciso I); (b) intimar pessoas para prestação de informações ou esclarecimentos (inciso II); (c) requisitar informações a órgãos públicos (inciso III); (d) determinar às companhias a republicação de demonstrações financeiras, relatórios ou informações (inciso IV).
} 
exercício do poder de polícia da CVM na imposição da Taxa de Fiscalização do mercado de títulos e valores mobiliários ${ }^{237}$, prevista na Lei n. ${ }^{\circ} 7.940 / 1989 .{ }^{238}$

\section{b) Função julgadora:}

No que tange à função julgadora ${ }^{239}$, trata-se de atribuição exercida pela CVM para dirimir conflitos entre a própria CVM, por intermédio de seus procuradores, e os agentes privados. Compete a ela julgar e punir irregularidades eventualmente cometidas no âmbito do mercado. Diante de suspeita, pode a CVM dar início a inquérito administrativo, por meio do qual recolhe informações, toma depoimentos e reúne provas com vistas a identificar claramente o responsável por práticas ilegais, oferecendo-lhe, a partir da acusação, amplo direito de defesa.

\section{c) Função de registro:}

Afora as funções fiscalizadora e julgadora, a CVM também exerce a função de registro. A existência deste sistema de registro, por meio da qual são armazenadas as informações consideradas necessárias para que o investidor faça suas escolhas, constitui, segundo Eizirik et al., fundamento para a política do disclosure. Ou seja, trata-se de um meio para se garantir a ampla divulgação das normas ao público. ${ }^{240}$

\footnotetext{
${ }^{237}$ Trata-se de taxa reconhecidamente legal, inclusive já positivada em Súmula. Dispõe a Súmula 15 do TRF da $5^{\mathrm{a}}$ Região: "É válida a cobrança da Taxa de Fiscalização dos Mercados de Títulos e Valores Mobiliários (Lei 7.940/89), com base em tabela, por faixas de contribuintes".

${ }^{238}$ Refere-se a tributo cuja hipótese de incidência prevê, em seu critério material, o registro junto à Comissão de Valores Mobiliários. Quanto ao critério pessoal, o sujeito passivo será, nos termos do artigo $3^{\circ}$ da Lei n. ${ }^{\circ}$ 7.940/1989: "as pessoas naturais e jurídicas que integram o sistema de distribuição de valores mobiliários, as companhias abertas, os fundos e sociedades de investimentos, os administradores de carteira e depósitos de valores mobiliários, os auditores independentes, os consultores e analistas de valores mobiliários e as sociedades beneficiárias de recursos oriundos de incentivos fiscais obrigadas a registro na Comissão de Valores Mobiliários - CVM". Sendo assim, é taxa que tem como contraprestação o exercício do poder de polícia, conforme o artigo 145, II, da Constituição, e pagam-na como condição para operar no mercado. Com isso, verificamos tratar-se de tributo devidamente instituído, cuja cobrança é realizada por meio do poder de polícia da própria CVM.

${ }^{239}$ Dispõe o artigo $9^{\circ}$, inciso V, que a CVM irá "apurar, mediante processo administrativo, atos ilegais e práticas não equitativas de administradores, membros do conselho fiscal e acionistas de companhias abertas, dos intermediários e dos demais participantes do mercado", sendo seguido pelo $\S 2^{\circ}$ que assevera que "o processo, nos casos do inciso $\mathrm{V}$ deste artigo, poderá ser precedido de etapa investigativa, em que será assegurado o sigilo necessário à elucidação dos fatos ou exigido pelo interesse público, e observará o procedimento fixado pela Comissão". Temos, ainda, o $§ 4^{\circ}$ do artigo 11, que determina a observância deste procedimento, para que penalidades sejam impostas.

${ }^{240}$ EIZIRIK, Nelson; GAAL, Ariadna B.; PARENTE, Flávia; HENRIQUES, Marcus de Freitas. op. cit., p. 137-138.
} 
Apenas a título ilustrativo, salientamos, dentre as informações que compõem este sistema, a norma prevista no caput do artigo 19 da Lei n. ${ }^{\circ} 6.385 / 1976$, que dispõe sobre a obrigatoriedade de prévio registro junto a Autarquia no caso de emissão pública de valores mobiliários. Ademais, há também o registro previsto no artigo 21 da mesma lei, que representa condição necessária para negociação na bolsa (inciso I), bem como no mercado de balcão, organizado ou não (inciso II), e que dispõe que somente aqueles valores mobiliários emitidos por companhias devidamente registradas podem ser negociados na bolsa e no mercado de balcão $\left(\S 1^{\circ}\right)$. Por fim, relembramos que o $\S 1^{\circ}$ do artigo $4^{\circ}$, da Lei n. ${ }^{\circ}$ 6.404/1976, abriga norma que dispõe que apenas companhias registradas na Comissão de Valores Mobiliários poderão ter seus valores mobiliários negociados no mercado.

Por este sistema de registro constituir um dos pilares que garantem ao mercado o amplo acesso a informação, sua não observância pode gerar graves consequências. Conforme relembra Eizirik et al., a realização de distribuição pública de valores mobiliários sem o prévio registro junto à Comissão de Valores Mobiliários, poderá incidir em penalidades advindas tanto da esfera administrativa, quanto da esfera civil e penal. ${ }^{241}$ No âmbito da CVM, haverá a suspensão ou cancelamento desta emissão ou ainda daquela que, embora registrada, tenha sido julgada ilegal ou fraudulenta, ou nos casos em que a oferta, promoção ou o anúncio dos valores esteja sendo feito em condições diversas daquelas constantes no registro, ou com informações falsas, dolosas ou substancialmente imprecisas. $^{242}$

\section{d) Função consultiva ou de orientação:}

À CVM também cabe a chamada função consultiva ou de orientação. A Comissão, nos termos do artigo 13 , da Lei n. ${ }^{\circ} 6.385 / 1976^{243}$, manterá serviço para exercer esta atividade junto aos agentes do mercado de valores mobiliários ou a qualquer investidor.

Seu exercício se dá por meio de manifestações de entendimento emitidas tanto de ofício quanto a pedido de interessados. Estas manifestações também contribuem para as iniciativas de fiscalização, especialmente quando prévias à realização de atos societários, quando então se revestem de caráter preventivo de disputas e de danos ao mercado. Além

\footnotetext{
${ }^{241}$ EIZIRIK, Nelson; GAAL, Ariadna B.; PARENTE, Flávia; HENRIQUES, Marcus de Freitas. op. cit., p. 160.

${ }^{242}$ Artigo 20, da Lei n. ${ }^{\circ}$ 6.385/1976 e artigo 19, da Instrução CVM n. ${ }^{\circ}$ 400/2003.

${ }^{243}$ Art. 13. A Comissão de Valores Mobiliários manterá serviço para exercer atividade consultiva ou de orientação junto aos agentes do mercado de valores mobiliários ou a qualquer investidor.
} 
disso, nos termos do artigo 31, da Lei n. ${ }^{\circ} 6.385 / 1976^{244}$, a CVM pode tomar parte em ações judiciais em matérias de sua competência, oferecendo pareceres ou prestando esclarecimentos.

\section{e) Função sancionadora:}

Já a função sancionadora se constitui na atribuição concedida à CVM, por meio do artigo 11 da Lei do Mercado de Capitais, para aplicar penalidades. Ao lado de criar as normas e fiscalizar sua correta observância, cabe também à Comissão impor punições em caso de seu descumprimento.

Dentre as penalidades que a Comissão de Valores Mobiliários poderá impor aos infratores da legislação pertinente ao mercado de capitais, cujo cumprimento lhe incumba fiscalizar, salientamos a advertência (inciso I), a multa (inciso II), suspensão ou inabilitação do exercício do cargo de administrador ou de conselheiro fiscal de companhia aberta, de entidade do sistema de distribuição ou de outras entidades que dependam de autorização ou registro na Comissão de Valores Mobiliários (incisos III e IV), suspensão ou cassação da autorização ou registro para o exercício das atividades de que trata a lei (incisos V e VI), proibição temporária de praticar determinadas atividades ou operações, para os integrantes do sistema de distribuição ou de outras entidades que dependam de autorização ou registro na Comissão de Valores Mobiliários (inciso VII) e proibição temporária de atuar, direta ou indiretamente, em uma ou mais modalidades de operação no mercado de valores mobiliários (inciso VIII).

\section{f) Função de fomento:}

O artigo $4^{\circ}$ da Lei n. ${ }^{\circ} 6.385 / 1976$, em seus incisos I e II, lança a função de fomento da Autarquia. ${ }^{245}$ Trata-se da adoção de medidas que buscam o desenvolvimento do mercado, a fim de estimular e promover sua expansão, bem como seu funcionamento

\footnotetext{
${ }^{244}$ Art. 31 - Nos processos judiciários, que tenham por objetivo matéria incluída na competência da Comissão de Valores Mobiliários, será esta sempre intimada para, querendo, oferecer parecer ou prestar esclarecimentos, no prazo de quinze dias a contar da intimação. (Incluído pela Lei no 6.616, de 16.12.1978).

${ }^{245}$ Art . 4 ${ }^{\circ}$ O Conselho Monetário Nacional e a Comissão de Valores Mobiliários exercerão as atribuições previstas na lei para o fim de:

I - estimular a formação de poupanças e a sua aplicação em valores mobiliários;

II - promover a expansão e o funcionamento eficiente e regular do mercado de ações, e estimular as aplicações permanentes em ações do capital social de companhias abertas sob controle de capitais privados nacionais;
} 
eficiente e regular. São atividades de ordem institucional, que visam a divulgar práticas salutares entre os agentes, além de promover investimentos no mercado.

Como exemplo, pode-se salientar o serviço de atendimento ao público para fornecimento de informações, bem como os programas de educação, tais como concurso de monografias sobre temas do mercado e convênio com universidades.

\section{g) Função normativa:}

Por fim, há previsões ao longo da Lei n. ${ }^{\circ}$ 6.385/1976 tratando da função normativa da Comissão de Valores Mobiliários. A função normativa, como se denota da própria expressão, consiste na atribuição da Autarquia de orientar comportamentos no mercado de capitais por meio da edição de normas jurídicas.

Trata-se de função decorrente da competência da Comissão para emitir comandos normativos ao mercado de capitais. É o que, por exemplo, identificamos no inciso I do artigo $8^{\circ}$, que dispõe sobre a competência da Comissão de Valores Mobiliários para regulamentar as matérias expressamente previstas nesta Lei e na Lei das Sociedades Anônimas.

Ademais, também nos deparamos com sua função normativa ao lermos o artigo 21A da Lei do Mercado de Capitais, o qual confere à CVM competência para expedir normas aplicáveis à natureza e periodicidade das informações a serem publicadas por quem tenha acesso à informação relevante.

De acordo com a Deliberação CVM n. ${ }^{\circ}$ 1, de 23 de fevereiro de 1978, os atos a serem expedidos pela Comissão são de sete espécies, conforme classificação abaixo:

(a) Deliberação: representa os atos de competência do Colegiado da CVM, nos termos do Regimento Interno;

(b) Instrução: ato através do qual a CVM regulamenta as matérias expressamente previstas nas Leis $n^{\circ} 6.404 / 1976$ e $n^{0} 6.385 / 1976$;

(c) Pareceres de Orientação: é o veículo por meio do qual a CVM orienta os agentes do mercado e os investidores, bem como veicula suas opiniões sobre interpretação das Leis n. ${ }^{\circ} 6.385 / 1976$ e n. ${ }^{\circ} 6.404 / 1976$; 
(d) Pareceres: contém manifestações da CVM em resposta às consultas específicas que lhe vierem a ser formuladas por agentes do mercado e investidores;

(e) Nota Explicativa: torna públicos os motivos que levaram a CVM a baixar norma ou apresentar proposição ao Conselho Monetário Nacional, além de fornecer explicações sobre a utilização da norma;

(f) Portaria: constitui atos que envolvam aspectos da administração interna da CVM;

(g) Ato Declaratório: veículo por meio do qual a CVM credencia ou autoriza o exercício de atividades no mercado de valores mobiliários.

\subsubsection{Funções da Comissão de Valores Mobiliários e o produto do seu exercício: a norma jurídica}

No tópico anterior discorremos acerca das oito principais funções exercidas pela Comissão de Valores Mobiliários. Apresentamos rapidamente uma definição de cada uma delas, bem como a forma como a CVM as desenvolve. Uma vez estabelecidos estes contornos, passaremos a relacioná-las com o poder normativo da Comissão, a fim de verificar se alguma destas funções possui caráter normativo, de forma a concluir se o seu exercício deverá ou não observar os limites impostos ao poder normativo da CVM.

Comecemos com a função consultiva ou de orientação. Conforme visto anteriormente, trata-se de função voltada ao esclarecimento de dúvidas advindas de agentes de mercado e investidores. Ainda, dentro desta função, há o papel de amicus curiae que será desempenhado pela CVM quando necessário.

Por tratar-se de função com caráter mais informativo, e não com caráter vinculativo, seu exercício não constitui fonte geradora de direitos ou deveres, i.e., não produz norma jurídica.

Na mesma esteira da atribuição consultiva ou de orientação da CVM, há também a função de fomento. O objetivo desta função, que se cristaliza por meio de atividades de ordem institucional, é o desenvolvimento do mercado de capitais. Não há, tampouco, no resultado de seu exercício, a criação de direitos ou imposição de deveres aos agentes 
econômicos. Com isso, resta claro que, apesar de tratar-se de função de enorme relevância, para fins de análise do poder normativo da CVM em nada pode contribuir.

Por conseguinte, passemos à função de registro da Comissão de Valores Mobiliários. O sistema de registro, como já dito, constitui fundamento para a política do disclosure, permitindo com isso aos investidores que façam suas escolhas devidamente informados. Normas prevendo sua necessidade podem ser encontradas em diversos dispositivos legais, constituindo, com isso, obrigação a seus destinatários, sob pena de incorrerem em ilícito em caso de descumprimento.

A observância destas normas imputará a seus destinatários o dever de ação, consubstanciado na necessidade de obter junto à Comissão de Valores Mobiliários documento autorizativo, como no caso da obrigatoriedade de prévio registro junto à Autarquia no caso de emissão pública de valores mobiliários. ${ }^{246}$ Este documento que formaliza o registro junto à Comissão, veicula uma regra concreta e individual, cujo sentido deôntico assim pode ser sinteticamente construído: "dado o fato de o agente cumprir com os requisitos exigidos, deve ser o seu registro junto à CVM, com os direitos e deveres respectivos."

Com isso, estamos diante da primeira função da CVM, dentre as até agora analisadas, cujo resultado do exercício gerará regra jurídica.

A função julgadora, para os fins que aqui pretendemos, será analisada conjuntamente com as funções fiscalizadora e sancionadora. A atribuição fiscalizadora da CVM, conforme veremos, fará, juntamente com a função sancionadora, parte do processo que, ao final, resultará em uma decisão - regra concreta e individual.

A análise conjunta dessas três funções, pelo prisma normativo, se dá pelo fato de que as duas primeiras integram o processo de produção de uma decisão, veiculadora de regra. As funções fiscalizadora e sancionadora por si só não resultam em regra que obrigue o agente a fazer ou deixar de fazer algo, pois dependem da decisão emitida pelo órgão julgador.

A título comparativo, em outras áreas da Administração Pública, como a tributária, a fiscalização pode resultar em regra concreta e individual. Em outras palavras: o agente público, ao encerrar uma fiscalização na qual entenda ter ocorrido algum descumprimento de norma tributária, lavra um auto de infração. Este auto de infração constituirá uma regra

\footnotetext{
${ }^{246}$ Caput do artigo 19, da Lei n. ${ }^{\circ} 6.385 / 1976$.
} 
que atribuirá ao contribuinte o dever de recolher o tributo, acrescido de eventuais encargos. Caso não concorde com os termos do auto, caberá ao contribuinte interpor recurso requerendo sua desconstituição ou modificação.

Diferentemente ocorre no âmbito do mercado de capitais. A Comissão de Valores Mobiliários, a fim de recolher informações, tomar depoimentos e reunir provas de forma a verificar eventual ocorrência de práticas ilegais, bem como eventual responsável, dá início a inquérito administrativo. Caso, ao final de suas investigações, conclua pela ilicitude da conduta do agente, lavrará termo de acusação, em relação ao qual o investigado terá amplo direito a defesa. Uma vez observadas todas as fases do processo administrativo, os autos serão remetidos para julgamento pela CVM. Será, com isso, nessa oportunidade, que a CVM exercerá sua função julgadora. Destarte, a fiscalização (função fiscalizadora) é processo que, por sua vez, pode resultar em um pleito (e não aplicação) de sanção (função sancionadora) ao agente. Todavia, apenas a decisão proveniente de julgamento (função julgadora) poderá resultar em regra sancionadora. Disso decorre a conclusão que as funções fiscalizadora e sancionadora não configuram produção normativa, decorrendo - tal qual uma estrutura de "guarda-chuva" - da função julgadora, conforme será ilustrado em esquema a seguir.

Exceção, todavia, ocorre no caso da aplicação de multa cominatória. Sua previsão, na Lei n. ${ }^{\circ}$ 6.385/1976, se dá em duas situações: primeiramente, no inciso II do artigo $9^{0247}$, e por conseguinte no inciso IV do $\S 1^{\circ}$ do artigo $9^{\text {o248 }}$. Esta multa, diferentemente daquelas impostas em decorrência da prática de ilícitos apurados no âmbito do processo administrativo sancionador, poderá ser aplicada pela CVM independentemente da instauração e decisão de processo administrativo ${ }^{249}$, conforme estabelece o $§ 11$ do artigo 11 , do referido diploma legal. ${ }^{250}$

\footnotetext{
${ }^{247}$ Art. $9^{\circ}$ A Comissão de Valores Mobiliários, observado o disposto no $\S 2^{\circ}$ do art. 15, poderá: (Redação dada pelo Decreto n 3.995, de 31.10.2001)

(...)

II - intimar as pessoas referidas no inciso I a prestar informações, ou esclarecimentos, sob cominação de multa, sem prejuízo da aplicação das penalidades previstas no art. 11; (Redação dada pela Lei no 10.303, de 31.10.2001).

${ }^{248}$ Art. $9^{\circ}(\ldots)$

$\S 1^{\circ}$ Com o fim de prevenir ou corrigir situações anormais do mercado, a Comissão poderá: (Redação pelo Decreto $\mathrm{n}^{\mathrm{o}} 3.995$, de 31.10.2001).

IV - proibir aos participantes do mercado, sob cominação de multa, a prática de atos que especificar, prejudiciais ao seu funcionamento regular.

${ }^{249}$ EIZIRIK, Nelson; GAAL, Ariadna B.; PARENTE, Flávia; HENRIQUES, Marcus de Freitas. op. cit., p. 333.

${ }^{250}$ Art. $11(\ldots)$

$\S 11$. A multa cominada pela inexecução de ordem da Comissão de Valores Mobiliários, nos termos do
} 
Ademais, salientamos também a Instrução CVM n. ${ }^{\circ}$ 452/2007, diploma responsável pela regulação da imposição de multas cominatórias às pessoas que deixarem de prestar as informações periódicas ou eventuais exigidas em atos normativos, ou, ainda, que deixarem de cumprir ordens específicas emitidas pela CVM (artigo $1^{\circ}$ ), cabendo ao superintendente da área responsável sua aplicação.

Como se pode ver, trata-se de regra concreta e individual, oriunda da aplicação da multa cominatória, cujo nascimento deu-se por meio do exercício da função fiscalizadora da CVM, e não da função julgadora. ${ }^{251}$

De outra banda, a competência para emitir regras abstratas e gerais está, por excelência, contida na função normativa da CVM. Não que esta seja a única das funções a ter como produto uma norma jurídica, nem mesmo que seu único produto seja uma regra abstrata e geral. Apenas salientamos tratar-se de função comumente abordada como o poder normativo da CVM para emitir regras abstratas e gerais, tanto no sentido de explicitar regras legais, quanto no sentido de regular situações não previstas na lei. Como exemplo, tem-se as instruções da CVM.

Além dessas regras abstratas e gerais, a função normativa também é incumbida de emitir soluções para casos específicos a requerimento dos agentes do mercado ou investidores. São, nos termos da Deliberação CVM n. ' 1/1978, os chamados "pareceres". Tratam-se, pelo prisma normativo, de regras concretas e individuais.

$\mathrm{Na}$ tentativa de meramente ilustrar a classificação das funções clássicas da Comissão de Valores Mobiliários dentro da ótica normativa, proposta do presente trabalho, segue abaixo figura que busca demonstrar que a produção de normas jurídicas pela CVM flui não apenas da sua chamada "função normativa", mas, na verdade, decorre do próprio poder normativo da agência.

inciso II do caput do art. $9^{\circ}$ e do inciso IV de seu $\S 1^{\circ}$ não excederá a R $\$ 5.000,00$ (cinco mil reais) por dia de atraso no seu cumprimento e sua aplicação independe do processo administrativo previsto no inciso V do caput do mesmo artigo. (Redação pelo Decreto n 3.995 , de 31.10.2001).

${ }^{251}$ Do entendimento que cominar na aplicação da multa, caberá recurso ao Colegiado da CVM ( $\$ 12$ do artigo 11, da Lei n. ${ }^{\circ}$ 6.385/1976). A decisão deste recurso, caso se mantenha a aplicação da penalidade, será uma regra concreta e individual, esta sim fruto do exercício da função julgadora da Autarquia. 


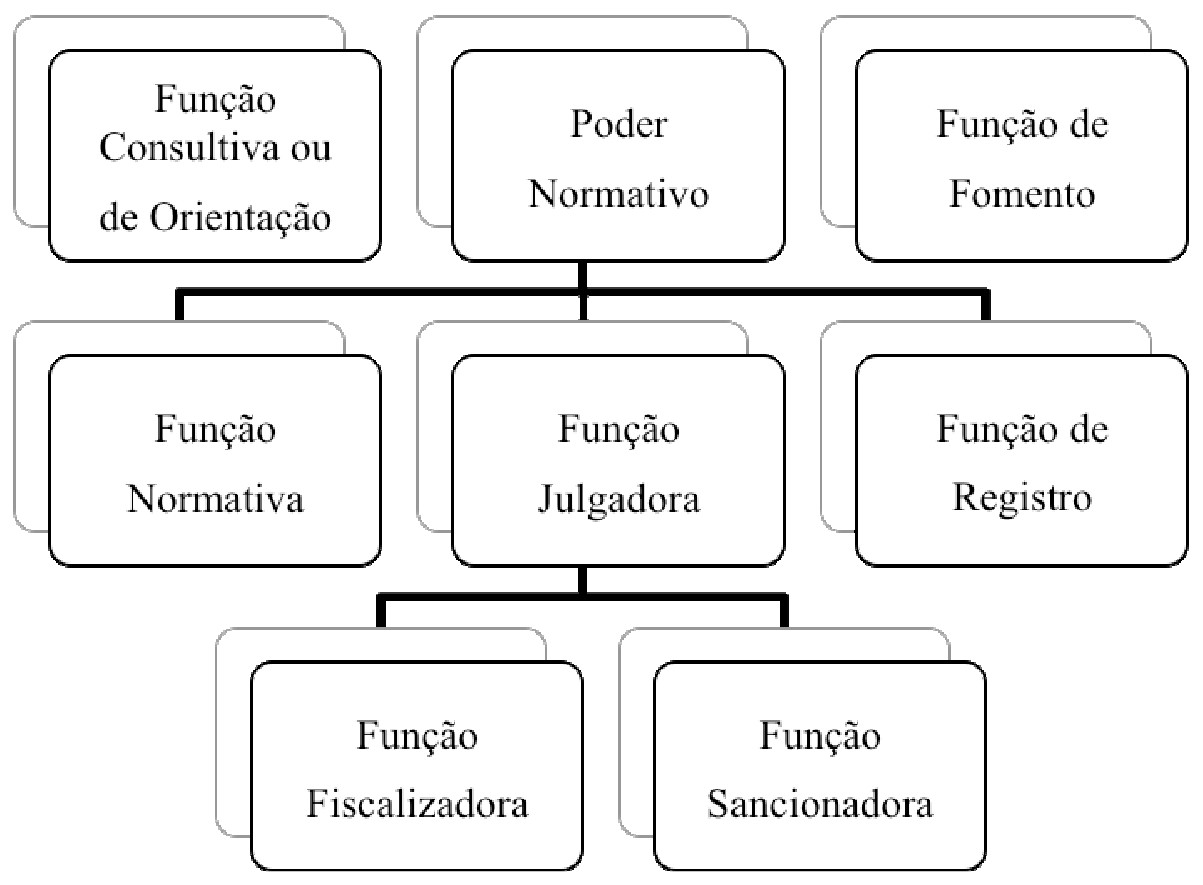

Conforme o esquema acima, as funções consultiva ou de orientação, bem como a função de fomento, encontram-se ladeando o poder normativo, sem traços que as conectem com a célula que o representa, por não possuírem o condão de, quando do seu exercício, produzirem norma jurídica. Não obstante sua importância e relevância, em face de não deterem o elemento normativo em sua finalidade, em nada relacionam-se com o exercício do poder normativo da CVM.

A função de registro decorre também do poder normativo, uma vez que dela são originadas regras concretas e individuais, conforme já dito linhas acima.

Por conseguinte, as funções fiscalizadora e sancionadora constituem elementos que compõem a função julgadora, sendo esta sim a função produtora de regras jurídicas. A sua posição no esquema demonstra que, embora não tenham o condão de produzir regras, integram o processo normativo.

Finalmente, a função normativa encontra-se separada das funções julgadora e de registro, sendo que todas igualmente decorrem do poder normativo da CVM. Com essa análise, fica demonstrada a distinção lógica entre o poder de criar normas jurídicas que o órgão possui, e uma das funções específicas que detém, sendo esta apenas um dos focos normativos. 


\subsection{Regulamentação e regulação: a competência híbrida da Comissão de Valores Mobiliários}

Até o presente momento, no que tange à competência normativa da Comissão de Valores Mobiliários, nos propusemos a estabelecer que por norma jurídica compreendemos todo e qualquer comando emanado por autoridade competente. Sejam elas as decisões proferidas pelo Colegiado da CVM, os termos de compromisso por ela firmados, as instruções por ela editadas, e assim por diante. Dito isso, passaremos a tratar dos limites impostos à Comissão no exercício desta competência.

Para isso, iniciamos apresentando a ideia de um órgão com competência híbrida. Isto é, uma competência que confira à Comissão de Valores Mobiliários poder para regulamentar determinadas matérias, e poder para regular os demais casos.

Tal competência atribuiria à CVM, por um lado, poder para formular normas que desdobrassem o conteúdo dos princípios e regras contidos nas Leis n. ${ }^{\circ}$ 6.385/1976 e n. ${ }^{\circ}$ 6.404/1976 quando assim elas previssem, e, por outro lado, poder para formular normas que suprissem a ausência ou omissão destes diplomas legais. Ou seja, a competência para editar normas que pormenorizem normas, ou que supram a sua omissão.

Estaríamos, assim, diante de uma competência que poderia ser desdobrada da seguinte forma: competência regulamentar e competência suplementar, sendo esta última a possibilidade de a CVM integrar o sistema jurídico, de forma a preencher lacunas normativas advindas de situações novas no mercado de capitais, cuja complexidade e dinamismo o legislador ordinário não poderia antever.

O poder regulamentador será circunscrito às situações previstas especificamente nas Leis das S/A e do Mercado de Capitais, enquanto o poder regulador, que também chamaremos de competência suplementar, deverá ser exercido dentro dos limites impostos pelo artigo $4^{\circ}$ e pela Constituição Federal. ${ }^{252}$

\footnotetext{
${ }^{252} \mathrm{O}$ art. $4 .^{\circ}$ da Lei n. ${ }^{\circ}$ 6.385/1976 guarda os limites finalísticos da regulação pela CVM, conforme José Alexandre Tavares Guerreiro: "os valores encampados pelo legislador de 1976 se acham discriminados, explicitamente, pelo art. $4{ }^{\circ}$ da Lei 6.385/76. Nessa enumeração programática e valorativa, encontram-se os fins justificadores do poder disciplinar da CVM, por consubstanciarem os próprios objetivos da autarquia. Isso equivale a dizer que o exercício do poder disciplinar somente se legitima na medida em que visa assegurar a consecução daqueles mesmos fins.” GUERREIRO, José Alexandre Tavares. Sobre o poder disciplinar da CVM. Revista de Direito Mercantil, Industrial, Econômico e Financeiro, São Paulo, v. 43, p. 66-67, 1981. Em sentido similar, Bolívar B. M. Rocha: Assim, há toda uma estrutura de atuação compondo a lei que criou a Comissão de Valores Mobiliários, definindo os objetivos que a Comissão irá perseguir e a
} 
Comecemos com a competência regulamentadora.

(a) A competência regulamentadora limita-se a explicitar as regras legais, dandolhes operatividade. Conforme a classificação de regulamentos que vimos, a categoria aplicável a essa competência seria a do regulamento executivo.

Não se pode negar que, por mais limitada que essa competência possa aparentar, sempre haverá margem de maior ou menor discricionariedade ao órgão, assim como sempre será necessária a criação de novas regras que explicitem as normas legais. Entretanto, novas regras acabarão por afetar, de alguma forma, o conteúdo semântico dos dispositivos legais.

Essa margem maior ou menor refere-se diretamente à determinação dos conceitos jurídicos, aqueles cujo conteúdo e extensão são em larga medida incertos, segundo lição de Karl Engish. ${ }^{253}$ Em rigor, não há propriamente uma distinção de natureza entre conceitos determinados e conceitos indeterminados, mas sim uma distinção de rau $^{254}$, pois toda palavra da linguagem natural, i.e., aquela que utilizamos para nos comunicarmos (em contraposição às linguagens formais da lógica e da matemática) são vagas e polissêmicas.

Como exemplos, os conceitos de "razoabilidade", "prudência" e "justiça" e, mais especificamente ao tema desse trabalho, os conceitos trazidos pelo art. $4^{\circ}$ da Lei n. ${ }^{\circ}$ 6.385/1976: funcionamento eficiente e regular do mercado de ações e dos mercados de bolsa e de balcão; práticas comerciais equitativas no mercado de valores mobiliários.

O que exatamente é um funcionamento "eficiente e regular", ou o que significam precisamente práticas comerciais "equitativas"? Estes são conceitos tipicamente indeterminados, que para além do seu núcleo duro de significação possuem zonas cinzentas, granuladas, imprecisas.

A função do órgão regulador, dados esses mandamentos legais indeterminados e outros com maior determinação, é positivar regras abstratas e gerais, bem como concretas e

forma como atuará, restringindo-lhe, portanto, o grau de discricionariedade, e vinculando seu poder normativo a objetivos e princípios definidos. ROCHA, Bolívar B. M. O poder normativo de órgãos da administração: o caso da Comissão de Valores Mobiliários. Revista de Direito Mercantil, Industrial, Econômico e Financeiro, São Paulo, v. 64, p. 67, 1986.

${ }^{253}$ ENGISH, Karl. Introdução ao pensamento jurídico. Trad. João Baptista Machado. 7. ed. Lisboa: Fundação Calouste Gulbenkian, 1996. p. 208.

${ }^{254}$ SOUSA, António Francisco de. Conceitos indeterminados no direito administrativo. Coimbra: Almedina, 1994. p. 24-25. 
individuais que confiram margens razoáveis de certeza e segurança jurídicas aos agentes e investidores no mercado. ${ }^{255}$

Entretanto, ainda que qualquer dispositivo, incluído nele os conceitos jurídicos, tenham diferentes graus de (in)determinação, o regulamentador não pode ultrapassar as margens de significação do texto legal, mesmo que essas sejam cinzentas. Dito de forma mais simples, se o artigo de lei dispõe que é "proibido" determinada conduta, não pode o órgão executivo, sob pretexto de regulamentá-lo, dispor em sentido contrário ou contraditório (obrigando ou permitindo, respectivamente). Mesmo conceitos indeterminados possuem razoáveis núcleos duros de significação, os quais devem ficar a salvo de manipulações indevidas a título de regulamentação.

(b) A competência suplementar, no dizer de José Afonso da Silva ${ }^{256}$, "significa o poder de formular normas que desdobrem o conteúdo de princípios ou normas gerais ou que supram a ausência ou omissão destas".

Em síntese, é competência cuja finalidade é integrar falhas ou lacunas do sistema normativo, quando há situações que exigem soluções jurídicas e faltam normas postas para tanto.

Cabe, neste diapasão, tecer alguns comentários quanto à possibilidade de integração de lacunas. Para a Teoria Geral do Direito ${ }^{257}$ a questão das lacunas se dá quando, em face de um caso concreto, o juiz não encontra no direito posto - sejam os códigos e leis dos sistemas romano-germânicos, sejam os precedentes da Common Law - nenhuma regra geral a qual possa subsumir sua decisão. Todavia, não pode o juiz abster-se de solucionar o litígio, pois há direitos e deveres correlatos que precisam ser alocados entre as partes. Como fazer, então?

\footnotetext{
${ }^{255}$ Nesse sentido, ao órgão regulador cabe aplicar e adaptar as regras legais aos fatos, conforme lição de Luiz Gastão Barros Leães: "Daí que a chamada polícia do mercado vem se desenvolvendo, através da habilitação por lei de um determinado órgão para agir, mediante atos e regulamentos, num determinado segmento da atividade privada. Estes, os regulamentos, apenas desenvolveriam o conteúdo, já previsto na lei, de normas disciplinadoras das relações entre particulares, sobre dispor sobre o modo de atuação das autoridades administrativas; aqueles, os atos, interviriam in concreto, condicionando a conduta privada no sentido do interesse geral. Mas sempre pressupondo uma lei que estabeleça os parâmetros dessa ação e propicie a habilitação do agente público. Lei essa, advirta-se, que revela aspectos originais, na medida em que os dispositivos constituem verdadeira "norma em branco", cujo conteúdo deverá ser preenchido pela entidade habilitada - e é fruto de uma técnica legislativa nova que se generaliza no direito econômico (chamada de fill-up details douctrine no direito anglo-americano). É, por exemplo, a técnica adotada pela legislação de mercado de capitais, em nosso país, instaurada pelas Leis n. 4.595, de 1964, e 4.728, de 1965.” LEÃES, L. G. Paes de Barros. Pareceres. São Paulo: Singular, 2004. v. 1, p. 13-14.

${ }^{256}$ SILVA, José Afonso da. op. cit., p. 456.

${ }^{257}$ Ver LARENZ, Karl. Metodológia de la ciencia del derecho. Trad. para o Espanhol de Marcelino Rodríguez Molinero. Barcelona: Ariel, 1994. p. 363.
} 
Para os juspositivistas, não há lacunas, uma vez que se não há obrigação ou proibição, necessariamente subsiste a permissão. ${ }^{258}$ Portanto, "tudo aquilo que não está proibido, está permitido", ainda que a permissão muitas vezes não seja expressa pelo legislador, mas meramente uma conclusão lógica. A lacuna, portanto, seria aparente, constituindo em uma permissão "fraca", como sustenta Georg von Wright ${ }^{259}$, o grande desenvolvedor da lógica deôntica.

De forma símile à posição acima, para Carlos E. Alchourron e Eugenio Bulygin ${ }^{260}$ o que estaria presente nesses casos não seria uma lacuna normativa propriamente dita, mas uma lacuna axiológica:

En el language de los juristas em general y muy especialmente em el de los jueces, se usa a menudo la expresión 'laguna del derecho'(o 'laguna de la ley') para designar situaciones em las cuales, sibien existe uma solución - por lo cual esas situaciones no son lagunas normativas - la solución existente es axiologicamente inadecuada. Pero no toda solución injusta o mala supone una laguna; los juristas hablan de lagunas - en el sentido que tratamos de caracterizar - cuando la solución es inadecuada porque el legislador no tuvo en cuenta una distinción que debía haber tomado en cuenta.

O problema é que tais soluções se limitam ao terreno da lógica, não satisfazendo os planos da semântica e da pragmática jurídicas. Em outras palavras, quando falta previsão expressa do legislador referente a determinados fatos (plano semântico), torna-se por demais incômodo o deslinde positivista, daí a solução axiologicamente inadequada (plano pragmático) acima citada.

Além disso, deve-se levar em conta também princípios gerais que portam valores e diretivas importantes, que cumprem a função de orientar a formação do próprio ordenamento e são úteis para os casos de integração sistêmica, além do tradicional método da analogia.

Transpondo o tema para a competência reguladora da CVM, percebe-se que a integração faz-se necessária não somente em soluções de casos concretos, mas igualmente

\footnotetext{
${ }^{258}$ Para Hans Kelsen, “verifica-se que a existência de uma 'lacuna' só é presumida quando a ausência de uma norma jurídica é considerada pelo órgão aplicado do Direito como indesejável do ponto de vista da política jurídica e, por isso, a aplicação - logicamente possível - do Direito vigente é afastada por esta razão político-jurídica, por ser considerada pelo órgão aplicador do Direito como não equitativa ou desacertada". KELSEN, Hans. Teoria pura do direito, cit., p. 274.

${ }^{259}$ WRIGHT, Georg von. Norm and action: a logical inquiry. London: Routledge \& Kegan Paul, 1977. p. 86.

${ }^{260}$ ALCHOURRON, Carlos E.; BULYGIN, Eugenio. Introducción a la metodología de las ciencias jurídicas y sociales. Buenos Aires: Astrea, 1993. p. 157-158.
} 
para suprir anomias para inovações trazidas pelo mercado. Destarte, a ação integradora é efetivada tanto na função julgadora quanto na função normativa exercidas pela agência.

Relembrando, uma vez mais, a classificação dos regulamentos apresentada em capítulo anterior, aponta-se que as normas, neste caso, editadas pela Comissão, guardariam identidade com os denominados regulamentos delegados, ou, ainda, como os denomina Eros $\mathrm{Grau}^{261}$, regulamentos autorizados. Tratam-se de regulamentos que regulam matérias que, muito embora não estejam detalhadamente disciplinadas em lei formal, nela encontram seu fundamento de validade. ${ }^{262}$

O ponto fulcral que insistimos é este: o gatilho, bem como a permissão à regulação pela Comissão de Valores Mobiliários, é a lacuna normativa. Apenas nesses casos pode a agência inovar no mundo jurídico, pois ao fazê-lo, atende ao mandamento geral da Constituição Federal, em seu artigo 174, bem como às finalidades gerais do $\operatorname{artigo} 4^{\circ}$, da Lei n. ${ }^{\circ} 6.385 / 1976$.

Em todas as demais situações em que houver previsão legal, seja por meio de comandos com maior ou menor determinação, a CVM deve se limitar somente a regulamentar tais normas.

A previsão de competência suplementar está presente na Constituição Federal em seu Título III, que trata da organização do Estado. Trata-se, neste caso, daquela competência que atribui aos Estados, ao Distrito Federal e aos Municípios a faculdade de complementar os princípios e normas gerais ${ }^{263}$ ou de suprir a omissão destes, nos termos dos $\S \S 2^{\circ}$ e $3^{\circ}$ do artigo 24 , e no inciso II do artigo 30 . Mas, conforme adverte Tércio

\footnotetext{
${ }^{261}$ GRAU, Eros Roberto. O direito posto e o direito pressuposto, cit., p. 188.

${ }^{262} \mathrm{Ou}$, ainda, nas palavras de Dinorá Adelaide Musetti Grotti, "são aqueles editados pelo Poder Executivo no exercício de competência normativa que lhe tenha sido atribuída pelo Legislativo, o qual, diante da existência de situações de fato extremamente mutantes, excessivamente técnicas ou politicamente complexas, limita-se a fixar os princípios gerais a serem seguidos pela autoridade administrativa na disciplina da matéria que constitui seu objeto.” GROTTI, Dinorá Adelaide Musetti. op. cit.

${ }^{263}$ Note-se que neste contexto o adjetivo "geral" não se confunde com a classificação já trazida neste trabalho, que se refere aos destinatários previstos pelas normas (gerais ou individuais). Na acepção acima, "geral" significa o alcance material da norma, i.e., comandos cujo conteúdo é propositadamente amplo, sem especificidades típicas de regras ordinárias de conduta. Por exemplo, o artigo $4^{\circ}$, inciso IV, alínea c, da Lei n. ${ }^{\circ} 6.385 / 1976$, veicula uma norma geral nesta acepção, que visa a proteção dos agentes de mercado contra a utilização de informação privilegiada, sem, contudo, estabelecer sanções específicas a infratores. Já o artigo 27-D, da mesma lei, que pune a utilização de informação relevante ainda não divulgada, determinando penalidades.
} 
Sampaio Ferraz Junior ${ }^{264}$, trata-se de um tipo de competência que deve ser exercido em concordância com as normas gerais da União e não na ausência delas.

Usualmente os constitucionalistas tratam do tema da competência aplicando-o apenas ao legislativo. O raciocínio comum é que enquanto ao legislativo cumpre fazer leis, ao executivo cabe apenas aplicá-las. A falácia desse argumento reside no fato de que a aplicação requer criação de normas, não sendo possível uma coisa sem a outra. Quando o aplicador, seja o agente administrativo, seja o juiz, aplica a regra abstrata e geral, o faz por intermédio de uma regra concreta e individual.

O que se quer dizer aqui é que competência, conforme já tratado nesse trabalho, significa a possibilidade de criar normas jurídicas, que podem advir de distintas fontes: legislativo (v.g. leis), executivo (v.g. instruções), judiciário (v.g., sentenças) e, também, dos próprios particulares (v.g. contratos). Cada uma dessas fontes tem a capacidade de criar normas apenas porque o sistema jurídica as autoriza a tanto. Logo, é no sistema que se deve procurar pelas regras que preveem as competências normativas e que autorizam o seu exercício.

Quando se trata da competência suplementar da CVM, devemos construí-la a partir da finalidade essencial do órgão, qual seja, regular o setor específico do mercado de capitais, com supedâneo na Constituição e nas Leis n. ${ }^{\circ}$ 6.385/1976 e n. ${ }^{\circ}$ 6.404/1976. Portanto, no que as leis dispuserem, somente poderá a CVM regulamentá-la; naquilo que as leis silenciarem, poderá então a CVM regular a conduta dos agentes.

\subsubsection{A competência regulamentadora da Comissão de Valores Mobiliários}

Considerando o quanto até aqui exposto, pode-se concluir que nas matérias tratadas pelas Leis n. ${ }^{\circ}$ 6.385/1976 e n. ${ }^{\circ}$ 6.404/1976, está a Comissão de Valores Mobiliários limitada a apenas regulamentá-las, não podendo alargar, restringir ou criar novas hipóteses normativas.

Conforme dispõe o inciso I do artigo $8^{\circ}$, da Lei do Mercado de Capitais, compete à CVM regulamentar as matérias expressamente previstas em seu corpo, bem como aquelas tratadas na Lei n. ${ }^{\circ}$ 6.404/1976. É clara a lei ao estabelecer, neste caso, os limites que

\footnotetext{
${ }^{264}$ FERRAZ JUNIOR, Tercio Sampaio. Normas gerais e competência concorrente. Revista da Faculdade de Direito da USP, São Paulo, v. 90, p. 250, 1995.
} 
deverão ser observados pela CVM ao cumprir com o comando previsto no referido inciso I. Trata-se, portanto, de restrição à função normativa da Autarquia.

Esta restrição pode ser decomposta em duas categorias, a saber: uma de cunho material e outra de natureza formal.

Quanto ao limite material, não há muito o que ser dito. Trata-se de limitação imposta ao âmbito de atuação normativo da agência. Ou seja, a CVM, ao exercer sua função normativa regulamentar, estará circunscrita àquelas matérias expressamente previstas nas Leis n. ${ }^{\circ} 6.385 / 1976$ e n. ${ }^{\circ} 6.404 / 1976$.

Já para analisarmos o limite de cunho formal, adotamos a definição de regulamento executivo proposta por Eros Roberto Grau ${ }^{265}$, segundo o qual o conteúdo desta norma será o desenvolvimento da lei, com a dedução dos comandos nela virtualmente abrigados. Portanto, por poder normativo regulamentar da CVM, compreendemos sua competência para emitir comandos complementares, a fim de explicitar e operacionalizar os direitos e deveres veiculados nas Leis n. ${ }^{\circ} 6.385 / 1976$ e n. ${ }^{\circ} 6.404 / 1976$.

Nesse sentido, caberia à CVM instituir regras de execução, cuja finalidade seria a de promover o fiel cumprimento e aplicação dos comandos das referidas legislações. Os atos por ela expedidos seriam, portanto, materialmente adstritos às questões de sociedades anônimas, nos termos impostos pela Lei n. ${ }^{\circ}$ 6.404/1976, e assuntos referentes ao sistema de distribuição de valores mobiliários, forma de negociação e intermediação nos mercados de valores mobiliários e derivativos, organização e funcionamento das Bolsas de Valores e de Mercadorias e Futuros, administração de carteiras e a custódia de valores mobiliários, auditoria nas companhias abertas, serviços de consultor e analista de valores mobiliários e dos crimes contra o mercado de capitais, nos limites expressamente conferidos pela Lei n. ${ }^{\circ}$ $6.385 / 1976$.

Qualquer compreensão diferente desta nos levaria a crer que um regulamento poderia ter prevalência sobre uma lei. Explica-se. Estamos diante de uma situação em que há duas leis ordinárias regulando condutas, e atribuindo a certo órgão a competência para regulamentar determinadas situações nelas expressamente ventiladas, desde que dentro dos limites por elas impostos. Ou seja, a Lei n. ${ }^{\circ} 6.385 / 1976$, em seu inciso I do artigo $8^{\circ}$, atribui à CVM competência para regulamentar as hipóteses expressamente por ela e pela Lei das Sociedades Anônimas escolhidas, dentro dos limites por elas previstos.

${ }^{265}$ GRAU, Eros Roberto. O direito posto e o direito pressuposto, cit., p. 187. 
Estes limites à função normativa da Comissão de Valores Mobiliários, importante ressaltar, não são sentidos apenas nas edições de normas gerais e abstratas como, por exemplo, uma Instrução. Estes limites estarão também presentes quando da aplicação da regra abstrata a um caso concreto, por meio, por exemplo, de uma decisão do Colegiado. Em outras palavras, ao decidir, o julgador administrativo deverá efetuar a subsunção do fato à norma legal, de forma a não criar novo direito além daquele previsto pelo legislador.

Neste mesmo sentido manifesta-se Marcelo Trindade ${ }^{266}$, em artigo no qual conclui não estarem afrontados dispositivos legais em razão das vedações à negociação de valores mobiliários constantes das Instruções CVM n. ${ }^{0}$ 358/2002 e n. ${ }^{\circ}$ 400/2003. Conclui o autor, ao analisar as Instruções da CVM frente aos artigos 27-D, da Lei n. ${ }^{\circ} 6.385 / 1976$, e artigo 155, § 4, da Lei n. ${ }^{\circ}$ 6.404/1976, que não pode a Comissão de Valores Mobiliários, sob pretexto de regulamentar norma legal, impor proibições não previstas em lei.

(...) assim agindo, a norma regulamentar não restringiu a lei regulamentada - o que a tornaria ilegal (...).

(...)

Qualquer outra interpretação permitiria que a norma regulamentar eliminasse o requisito subjetivo para a prática do insider trading ou vedasse a negociação em casos não previstos na própria lei. E, se isso ocorresse, estar-se-ia diante de patente ilegalidade (...).

Concluímos, portanto, que ao interpretarmos a norma posta no inciso I, no que se refere ao poder normativo da Comissão de Valores Mobiliários, ela estará sempre limitada a apenas emitir regulamentos executivos, a fim de dar fiel execução às matérias expressamente previstas nos referidos diplomas legais.

\subsubsection{O inciso I do artigo $8^{\circ}$, da Lei n. ${ }^{\circ}$ 6.385/1976 e a Instrução CVM n. ${ }^{\circ}$ 480/2009: a divulgação da remuneração dos administradores}

Não obstante a clareza da redação do inciso I do artigo $8^{\circ}$, da Lei n. ${ }^{\circ}$ 6.385/1976, por vezes a Comissão de Valores Mobiliários, por meio de edição de norma tratando de matéria expressamente prevista nas Leis das Sociedades Anônimas e do Mercado de

\footnotetext{
${ }^{266}$ TRINDADE, Marcelo. Vedações à negociação de valores mobiliários por norma regulamentar: interpretação e legalidade. In: ADAMEK, Marcelo Vieira von (Coord.). Temas de direito societário e empresarial contemporâneos. São Paulo: Malheiros Ed., 2011. p. 458-463.
} 
Capitais, extrapola os limites de sua competência normativa regulamentar. Isso se dá quando norma editada pela CVM, cuja finalidade é dar executoriedade aos comandos das duas legislações mencionadas, cria novos direitos, deveres ou obrigações aos agentes.

Um bom e recente exemplo que se pode utilizar para ilustrar esta situação é o caso da Instrução CVM n. ${ }^{\circ} 480$, de 7 de dezembro de 2009, e posteriores alterações promovidas pelas Instruções CVM n. ${ }^{\circ}$ 488/2010, n. ${ }^{\circ}$ 509/2011 e n. ${ }^{\circ}$ 511/2011, que dispõe sobre o registro de emissores de valores mobiliários admitidos à negociação em mercados regulamentados de valores mobiliários. ${ }^{267}$ Trata-se de norma que produz impacto direto na sistemática de divulgação das informações das companhias.

Ao analisar-se tal inovação sob o ponto de vista informacional, percebe-se tratar-se de norma muito bem-vinda, pois não apenas confere maior agilidade aos processos de registro de ofertas de distribuição de valores mobiliários, como também promove o fluxo de informações junto aos investidores. Dessa forma, custos de transação, especialmente os de procura, são minimizados por tal regulação, cujo efeito é também diminuir a assimetria de informação entre os agentes ${ }^{268}$.

Não obstante potenciais benefícios trazidos consigo pela Instrução, sua publicação foi também acompanhada por algumas críticas. Possivelmente a maior polêmica ${ }^{269}$, que é inclusive a que aqui nos interessa, refere-se à exigência contemplada em seu anexo 24, subitem 13.11, que determina a indicação para os 3 últimos exercícios sociais, em relação ao conselho de administração, à diretoria estatutária e ao conselho fiscal, dos valores da maior remuneração individual, da menor remuneração individual e da remuneração individual média, além do número de membros de cada órgão.

\footnotetext{
${ }^{267}$ Conforme disposto no Edital da Audiência Pública n. ${ }^{0} 07$ de 2008, a Instrução CVM 480/2009 teve como inspiração o modelo de registro que a International Organization of Securities Commissions (IOSCO) denomina de shelf registration system. De acordo com esse modelo, todas as informações referentes ao emissor são reunidas em um único documento que deve ser arquivado junto ao órgão regulador e ser atualizado regularmente. Para cumprir as funções deste documento (o shelf document), foi criado o Formulário de Referência. Com a adoção desse sistema, ao realizar uma oferta pública de distribuição de valores mobiliários, o emissor elabora somente um documento suplementar, relativamente curto. COMISSÃO DE VALORES MOBILIÁRIOS. Disponível em: <www.cvm.gov.br>. Acesso em: 24 ago. 2011.

${ }^{268} \mathrm{~A}$ respeito da seleção adversa e de outros problemas relacionados ou decorrentes da assimetria informacional, consultar: YAZBEK, Otavio. Regulação do mercado financeiro e de capitais. 2 ed. Rio de Janeiro: Elsevier, 2009. p. 37-45.

${ }^{269}$ Tal celeuma chegou ao judiciário por meio de ajuizamento de ação pelo Instituto Brasileiro de Executivo

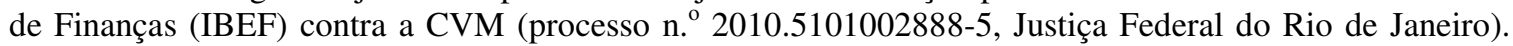
Em sede de antecipação de tutela, foi requerida a sustação provisória da eficácia do subitem 13.11 aos associados do IBEF, bem como às demais sociedades a ele vinculadas, para, ao final, pleitear o afastamento definitivo da aplicação da referida exigência.
} 
Como fundamentação legal quando da aprovação da Instrução n. ${ }^{\circ} 480$ pelo Colegiado da Comissão, foram ventilados os artigos 21 e 22 da Lei n. ${ }^{\circ}$ 6.385/1976. Com efeito, dispõem os incisos I e V do $\S 1^{\circ}$, do artigo 22:

Art . 22. (...)
$\S 1^{\circ}$ - Compete à Comissão de Valores Mobiliários expedir normas
aplicáveis às companhias abertas sobre: (Redação dada pelo Decreto $\mathrm{n}^{\circ}$
$\underline{3.995, \text { de } 31.10 .2001)}$
I - a natureza das informações que devam divulgar e a periodicidade da
divulgação; (Redação dada pelo Decreto $\mathrm{n}^{\circ} 3.995$, de 31.10 .2001$)$
$(\ldots)$
V - informações que devam ser prestadas por administradores, membros
do conselho fiscal, acionistas controladores e minoritários, relativas à
compra, permuta ou venda de valores mobiliários emitidas pela
companhia e por sociedades controladas ou controladoras; (Redação dada
pelo Decreto $\mathrm{n}^{\circ} 3.995$, de 31.10 .2001$)$

Verifica-se, com isso, que a criação do subitem 13.11 do anexo 24, Instrução CVM n. ${ }^{\circ} 480$ teve como fundamento legal sua atribuição genérica para expedir normas referentes à natureza e periodicidade das informações a serem divulgadas pelas companhias abertas (inciso I), bem como especificamente quais informações devem ser prestadas por administradores em geral sobre a negociação, por eles, de valores mobiliários emitidos pela companhia (inciso V).

Ora, sabe-se que de fato há dispositivo legal ${ }^{270}$ conferindo à CVM competência para regulamentar as matérias expressamente previstas nas Lei $\mathrm{n}^{\circ}{ }^{\circ} 6.385 / 1976 \mathrm{e} \mathrm{n.}{ }^{\circ}$ 6.404/1976. Logo, sabe-se também que a ela é dada a prerrogativa para regulamentar as hipóteses previstas nos artigos 21 e 22, da Lei n. ${ }^{o}$ 6.385/1976. Entretanto, o uso desta atribuição deve, por óbvio, ser efetivada levando em conta os demais dispositivos legais das leis acima referidas. A interpretação deve, por óbvio, ser sistemática, observando coordenações horizontais entre as normas.

No caso em tela, os incisos I e $\mathrm{V}$ do $\S 1^{\circ}$, do artigo 22 , da Lei . $^{\circ}$ 6.385/1976 veiculam norma genérica, enquanto o artigo 152 da Lei n. ${ }^{\circ}$ 6.404/1976 veicula comando mais específico. Este tem preponderância sobre aquele, ou, pelo menos, deveria ter, pois seu conteúdo semântico tem maior grau de determinação. Neste caso, prevê o referido

\footnotetext{
${ }^{270}$ Inciso I do artigo $8^{\circ}$, da Lei n. ${ }^{\circ} 6.385 / 1976$.
} 
artigo 152 que cabe à assembleia geral fixar o montante global ou individual da remuneração dos administradores, inclusive benefícios de qualquer natureza.

Art. 152. A assembleia-geral fixará o montante global ou individual da remuneração dos administradores, inclusive benefícios de qualquer natureza e verbas de representação, tendo em conta suas responsabilidades, o tempo dedicado às suas funções, sua competência e reputação profissional e o valor dos seus serviços no mercado. (Redação dada pela Lei $\mathrm{n}^{\circ} 9.457$, de 1997)

Trata-se, portanto, de atribuição conferida legalmente à assembleia geral, que decidirá se fixará a remuneração de forma global ou, eventualmente, de forma individual, quando, então, a informação sobre a remuneração restará sendo pública.

Afora a previsão contida no artigo 152, importante também salientar o artigo 157 da Lei das Sociedades Anônimas, que estabelece que os administradores de companhia aberta, a pedido de acionistas que representem $5 \%$ ou mais do capital social, têm o dever de prestar as seguintes informações:
Art . 157. (...)
$\S 1^{\circ} \mathrm{O}$ administrador de companhia aberta é obrigado a revelar à assembleia-geral ordinária, a pedido de acionistas que representem $5 \%$ (cinco por cento) ou mais do capital social:
a) o número dos valores mobiliários de emissão da companhia ou de sociedades controladas, ou do mesmo grupo, que tiver adquirido ou alienado, diretamente ou através de outras pessoas, no exercício anterior;
b) as opções de compra de ações que tiver contratado ou exercido no exercício anterior;
c) os benefícios ou vantagens, indiretas ou complementares, que tenha recebido ou esteja recebendo da companhia e de sociedades coligadas, controladas ou do mesmo grupo;
d) as condições dos contratos de trabalho que tenham sido firmados pela companhia com os diretores e empregados de alto nível;
e) quaisquer atos ou fatos relevantes nas atividades da companhia.

Dentre as alíneas acima colacionadas, salienta-se as informações que deverão ser prestadas em observância à alínea "c", que confere aos acionistas a possibilidade de requerer ao administrador informação acerca dos benefícios ou vantagens indiretas ou complementares que tenha recebido ou esteja recebendo da companhia e de sociedades coligadas, controladas ou do mesmo grupo. 
Ademais, os $\S \S 5^{\circ}$ e $6^{\circ}$ do mesmo artigo 157 conferem à $\mathrm{CVM}$ as seguintes atribuições:

$\S 5^{\circ}$ Os administradores poderão recusar-se a prestar a informação $\left(\S 1^{\circ}\right.$, alínea e), ou deixar de divulgá-la $\left(\S 4^{\circ}\right)$, se entenderem que sua revelação porá em risco interesse legítimo da companhia, cabendo à Comissão de Valores Mobiliários, a pedido dos administradores, de qualquer acionista, ou por iniciativa própria, decidir sobre a prestação de informação e responsabilizar os administradores, se for o caso.

$\S 6^{\circ}$ Os administradores da companhia aberta deverão informar imediatamente, nos termos e na forma determinados pela Comissão de Valores Mobiliários, a esta e às bolsas de valores ou entidades do mercado de balcão organizado nas quais os valores mobiliários de emissão da companhia estejam admitidos à negociação, as modificações em suas posições acionárias na companhia. (Incluído pela Lei n ${ }^{\circ} 10.303$, de 2001)

Percebe-se, com isso, que o artigo 157, ao tratar das informações que poderão ser requeridas pelos acionistas, não inclui em seu rol o valor da remuneração individual dos administradores.

Não obstante, com a edição da Instrução CVM n. ${ }^{\circ} 480$ passou a ser exigida a indicação dos valores da maior remuneração individual, da menor remuneração individual e da remuneração individual média, além do número de membros de cada órgão. Trata-se, pois, de norma que impõe novos deveres aos administradores, afora aqueles já elencados na Lei das Sociedades por Ações.

\subsubsection{A competência suplementar reguladora da Comissão de Valores Mobiliários}

Uma vez delimitada a atuação regulamentar da Comissão, no que tange às matérias expressamente previstas nas Leis n. ${ }^{\circ}$ 6.385/1976 e n. ${ }^{\circ}$ 6.404/1976, passemos à análise do poder normativo regulador da Comissão de Valores Mobiliários.

Para tratarmos deste tema, entendemos ser pertinente, neste momento, retomarmos a leitura da Lei n. ${ }^{\circ} 6.385 / 1976$, de modo a analisarmos a redação do artigo $4^{\circ}$, que assim dispõe:

Art. 4º O Conselho Monetário Nacional e a Comissão de Valores Mobiliários exercerão as atribuições previstas na lei para o fim de:

I - estimular a formação de poupanças e a sua aplicação em valores 
mobiliários;

II - promover a expansão e o funcionamento eficiente e regular do mercado de ações, e estimular as aplicações permanentes em ações do capital social de companhias abertas sob controle de capitais privados nacionais;

III - assegurar o funcionamento eficiente e regular dos mercados da bolsa e de balcão;

IV - proteger os titulares de valores mobiliários e os investidores do mercado contra:

a) emissões irregulares de valores mobiliários;

b) atos ilegais de administradores e acionistas controladores das companhias abertas, ou de administradores de carteira de valores mobiliários;

c) o uso de informação relevante não divulgada no mercado de valores mobiliários. (Alínea incluída pela Lei $\mathrm{n}^{\circ} 10.303$, de 31.10.2001)

V - evitar ou coibir modalidades de fraude ou manipulação destinadas a criar condições artificiais de demanda, oferta ou preço dos valores mobiliários negociados no mercado;

VI - assegurar o acesso do público a informações sobre os valores mobiliários negociados e as companhias que os tenham emitido;

VII - assegurar a observância de práticas comerciais equitativas no mercado de valores mobiliários;

VIII - assegurar a observância no mercado, das condições de utilização de crédito fixadas pelo Conselho Monetário Nacional.

Nos termos da redação do caput do artigo $4^{\circ}$, as hipóteses normativas elencadas em seus incisos tratam de finalidades que deverão ser almejadas pelo Conselho Monetário Nacional e pela Comissão de Valores Mobiliários, no exercício de suas atribuições. Aqui, nos parece indispensável um maior esforço reflexivo para compreendermos o alcance que pode ser dado à interpretação do texto do caput do artigo $4^{\circ} .^{271}$

Em uma primeira leitura, pode parecer bastante claro que o dispositivo refere-se a finalidades a serem alcançadas pela Comissão de Valores Mobiliários. Quando a lei fala em "exercício das atribuições previstas na lei para o fim de", ela refere-se àquelas atribuições dispostas tanto nos incisos do artigo $8^{\circ}$, quanto nas demais normas de competência distribuídas pelas Leis das Sociedades Anônimas e do Mercado de Capitais. Ou seja, refere-se ao exercício das funções da CVM, notadamente as funções normativa,

\footnotetext{
${ }^{271}$ Para fins deste trabalho, nos limitaremos à análise apenas dos aspectos referentes à Comissão de Valores Mobiliários, deixando de lado a referência ao Conselho Monetário Nacional.
} 
fiscalizadora, julgadora, sancionadora, de registro, consultiva ou de orientação e de fomento.

Portanto, a Comissão, ao fazer uso das regras de competência previstas em ambos diplomas legais, deverá buscar o objetivo de atingir as grandes finalidades elencadas nos incisos do acima colacionado artigo $4^{\circ}$.

Dessa forma, ao interpretá-lo conjuntamente com o inciso I do artigo $8^{\circ}$, que confere à CVM competência para regulamentar as matérias expressamente previstas nas Leis n. ${ }^{\circ}$ 6.385/1976 e n. ${ }^{\circ} 6.404 / 1976$, concluímos pela seguinte leitura: o exercício da função normativa pela CVM, ao emitir tais regulamentos, deverá ser pautado pelas metas constantes no artigo $4^{\circ}$, i.e., a CVM deverá almejar alcançar os valores do artigo $4^{\circ}$ por meio da edição de regulamentos, dentro dos limites permitidos pelas leis.

Entretanto, compreender que o poder normativo da Comissão de Valores Mobiliários esgota-se na regulamentação das matérias expressamente previstas nas Leis das Sociedades Anônimas e do Mercado de Capitais, seria não apenas uma postura por demais legalista, como também prejudicial à própria dinâmica do mercado.

Conforme o quanto já exposto, compreendemos que, no que concerne às matérias expressamente previstas nas Leis das Sociedades Anônimas e do Mercado de Capitais, não há dúvidas quanto aos limites materiais que a regulamentação pela CVM deverá respeitar, inclusive ao buscar satisfazer os valores elencados no artigo $4^{\circ}$.

Entretanto, como fica o tratamento de matérias não constantes das Leis n. ${ }^{\circ}$ 6.385/1976 e n. ${ }^{\circ}$ 6.404/1976, mas que ainda assim intrinsecamente ligadas ao mercado de capitais? Deverá a Comissão de Valores Mobiliários eximir-se de julgar questões, bem como emitir pareceres que versem sobre matérias não reguladas pelas referidas legislações? Diante disso, não estaria a Comissão de Valores Mobiliários renunciando às metas a ela impostas no artigo $4^{\circ}$ ? E ao renunciar a estas metas, não poderia ela estar conferindo uma maior insegurança e ineficiência ao mercado? Inclusive deixando de proteger os agentes que nele atuam?

A resposta, em nosso entender, é negativa. A função da CVM, enquanto órgão regulador do mercado, é justamente suprir normativamente situações não previstas pelo 
legislador ordinário. Se assim não o fizer, estará falhando em sua missão. Nesse sentido, vale colacionar a lição de Luiz Gastão Barros Leão ${ }^{272}$ :

\begin{abstract}
"Ora, somos daqueles que sustentam que, se o poder regulamentar é em somos também daqueles que acreditam que o poder regulamentar do Executivo não pode exaurir-se no papel de fiel execução de leis precedentes, já que a boa execução da lei, prevista na norma constitucional, não se esgota na execução de cada lei, mas se espraia numa dinamização da ordem legislativa, donde serem admissíveis os regulamentos autorizados, e até os independentes, que dispõe livremente sobre matéria não disciplinada por lei específica, mas sobre a qual não haja vedação constitucional."
\end{abstract}

\title{
3.4.2.1. Eficiência, legalidade e segurança jurídica
}

Ao ventilarmos a possibilidade de atribuir-se à Comissão de Valores Mobiliários competência normativa para inovar no sistema jurídico, mesmo que apenas em casos específicos, impõe-se apresentar certos esclarecimentos.

A atuação das agências reguladoras no Brasil sempre foi alvo de uma disputa mais ideológica que propriamente jurídica. De uma lado, os defensores dos limites de atuação, calcados no "princípio da legalidade"; de outro, os propugnadores de maior liberdade de atuação, apoiados em princípios e valores como a eficiência e a especialidade.

Considerando que as teses invariavelmente se subsomem a questões constitucionais e principiológicas, cabe agora analisar quais desses mandamentos constitucionais invocados são princípios, quais são regras, e - principalmente - quais são fundamentais na justificação da regulação pelas agências, dentre elas, a Comissão de Valores Mobiliários.

Se os argumentos pudessem ser colocados em uma balança, poder-se-ia dizer que em um dos pratos encontra-se a eficiência e, no outro, a legalidade. Mas seriam, em termos normativos, entidades de mesma natureza? Dito de outra forma, seriam princípios de igual carga axiológica, os quais podem entrar em colisão?

Comecemos com três asserções, as quais justificaremos em seguida: (a) a eficiência é um mero valor "meio", de natureza instrumental; (b) a legalidade é regra, não princípio; (c) a legalidade é sobrevalorizada como salvaguarda de direitos fundamentais e da segurança jurídica.

${ }^{272}$ LEÃES, L. G. Paes de Barros. Mercado de capitais \& insider trading, cit., p. 36 e ss. 


\section{a) A eficiência é um mero valor "meio", de natureza instrumental}

A eficiência, já abordada neste trabalho, é valor de natureza instrumental, i.e., sua função é prática. Não é por menos que a área de conhecimento humano que mais lida com essa categoria é a Economia, ciência que trabalha com escolhas humanas em um contexto de recursos escassos. Uma vez que tais escolhas e decisões implicam alocações de recursos limitados, a eficiência torna-se crucial, pois fará a diferença entre excedente e perda de bem-estar.

Aplicada ao Direito, a eficiência implica em escolhas menos custosas, seja para as partes envolvidas em um litígio, seja para os cidadãos destinatários das regras abstratas e gerais. O legislador que cria regras instituidoras de direitos e deveres deve seguir os preceitos da eficiência, por meio de análise custo-benefício em relação aos objetivos que pretende alcançar, e os meios respectivos que irá empregar para tanto.

Conforme já exposto, quando a palavra "eficiência" é empregada no contexto da administração pública, usualmente a acepção é de racional emprego dos recursos públicos, buscando alcançar metas com o menor desperdício possível. Ou, ainda, que em razão do princípio da eficiência que se exige que a "Administração, em vista do mercado, seja dotada de competências reguladoras de natureza técnica e especializada sob pena de paralisia. Isto é, é impossível exigir-se eficiência da Administração sem dar-lhe competência para alocar fins específicos e encontrar meios correspondentes. A especialização técnica é exigência da eficiência." 273

Quando se trata de órgãos do poder executivo cuja atuação é estritamente delimitada pela lei, não há grandes celeumas a respeito da eficiência, pelo contrário, é valor que se espera ver cumprido pela administração. Todavia, quando a eficiência é utilizada como argumento superador da legalidade, vozes discordantes se levantam e polêmica tem início.

A eficiência, contudo, não é um fim ou uma meta a ser alcançada, mas um valor instrumental, que serve para alcançar objetivos tidos como importantes pelo agente. Quando se diz que a regulação por parte das agências se baseia na eficiência, significa dizer que os objetivos devem ser alcançados com a forma menos custosa para o poder público, o que, em última instância, reflete em menor custo para os cidadãos.

\footnotetext{
${ }^{273}$ FERRAZ JUNIOR, Tercio Sampaio. Como regular agências reguladoras?, cit., p. 10.
} 
A eficiência, por ser instrumental, poderia ser confundida com regra jurídica, pois esta é sempre meio para alcançar algum objetivo pretendido pelo legislador. Entretanto, a eficiência contém a vagueza e carga axiológica típicas dos princípios jurídicos, sempre de difícil determinação. Ainda que o vocábulo "eficiência" contenha um núcleo duro, cuja definição já foi aqui exposta, aferir a sua ocorrência no mundo dos fatos nem sempre é tarefa simples, resvalando não raro em juízos subjetivos.

Se as finalidades da Comissão de Valores Mobiliários refletem valores imediatos e mediatos, conforme vistos no tópico inicial desta dissertação, quais sejam, possibilitar o acesso à informação e coibir práticas não equitativas pelos agentes, de modo a que o mercado seja um ambiente seguro, estável e gerador de bem-estar social, as ações empregadas para isso devem ser - por óbvio - eficientes. ${ }^{274}$

\section{b) Legalidade é regra, não princípio}

A porção majoritária da doutrina jurídica pátria, bem como a continental europeia, qualifica a legalidade como um princípio jurídico, sempre alçado ao patamar dos valores fundamentais de qualquer Estado Democrático de Direito. Mas será assim mesmo? Entendemos que a legalidade não é valor, mas sim regra. Em termos de razão prática, por ser regra, a legalidade consubstancia-se em mero instrumento de consecução de valores.

Quando se diz que uma regra cumpriu a legalidade, simplesmente significa que o veículo normativo que a inseriu no sistema foi a lei, em sentido amplo, ou seja, veículo emanado pelo poder legislativo.

Por ser de origem legislativa, os comandos são produtos de um processo de construção inerentemente democrático, pressupondo projetos de lei, debates, votações, vetos e sanção do chefe do executivo, enfim, um longo trajeto até a sua ponência no ordenamento. Justamente por isso é que - usualmente - o valor fundamental da segurança jurídica resta melhor atendido por regras postas pela lei.

A legalidade, ainda assim, é regra, e por uma simples razão. Para verificar o seu cumprimento, como esclarece Cristiano Carvalho ${ }^{275}$, basta verificar se a regra que inovou no mundo jurídico, criando novos direitos e deveres, foi posta por lei. É algo objetivamente

\footnotetext{
274، A competência das agências reguladoras funda-se na própria exigência constitucional de racionalidade que informa aquela competência: a de que se deve criar um ambiente onde o próprio mercado funcione, mediante a indução de comportamentos." Id. Ibid., p. 14.

${ }^{275}$ CARVALHO, Cristiano. Ficções jurídicas no direito tributário. São Paulo: Noeses, 2008. p. 265.
} 
verificável, não sujeito a juízos subjetivos de valor, como ocorre com os princípios. Tratase, assim, de um limite objetivo, como ensina Paulo de Barros Carvalho. ${ }^{276}$

Por ser uma regra, estaria a legalidade em posição menos importante em relação a algum princípio, podendo, por exemplo, ser desprezada em prol daquele? De forma alguma. Não se pode olvidar que a regra da legalidade é direito individual na Constituição Federal. Trata-se de garantia que o constituinte alçou ao patamar de cláusula pétrea, ao salvo até de alterações por via constituinte derivada.

Além disso, na dinâmica de aplicação do sistema jurídico, as regras devem prevalecer em relação aos princípios. Por exemplo: ignorar as regras legais previstas em códigos e leis esparsas com o pretexto de melhor cumprir a Constituição e decidir casos com base apenas em princípios, paradoxalmente iria de encontro à própria segurança jurídica, fundação da ordem constitucional.

Assim, salvo em situações excepcionais - quando há lacunas normativas, e mesmo a analogia não se adapta à solução da situação concreta, o aplicador pode então buscar como fundamento argumentativo para a regra $a d$ hoc, os princípios gerais.

Nem por isso, cumpre advertir, a regra da legalidade - e da mesma sorte, em relação aos demais direitos fundamentais, sejam princípios ou regras - é absoluta. Em diversas situações, a legalidade é posta de lado em prol de outras meios com maior potencial para solução do problema ou para obtenção dos fins pretendidos. Desde, por óbvio, que a liberdade individual não seja violada além dos limites necessários para a manutenção do Estado Democrático de Direito.

c) A legalidade é sobrevalorizada como salvaguarda de direitos fundamentais e da segurança jurídica

Esta terceira e última asserção é, provavelmente, a mais polêmica. Todavia, decorre das duas primeiras, pois, se consideramos que a legalidade é apenas mais uma das regras constitucionais, mesmo que direito individual e cláusula pétrea, não é condição suficiente e nem sequer necessária - para se alcançar os valores fundamentais do ordenamento, a saber, segurança jurídica, isonomia e devido processo legal.

${ }^{276}$ CARVALHO, Paulo de Barros. Curso de direito tributário, cit., p. 141. 
Sendo assim, o principal argumento de tantos doutrinadores, no sentido de retirar das agências a sua possibilidade de inovação na ordem jurídica torna-se consideravelmente mais frágil. Se o segmento regulado exige do regulador certas características que o legislador não possui, tais como conhecimento especializado, agilidade, em suma, eficiência, os valores fundamentais referidos poderão ser melhor cumpridos relativizandose (o que não significa retirar ou anular) a exigência de lei.

Cumpre lembrar, apenas a título argumentativo, que se a legalidade fosse, de fato, fundamental para a manutenção das liberdades individuais, países como os Estados Unidos, que sequer a mencionam em sua Constituição, seriam exemplo de autoritarismo, quando o que ocorre é justamente o oposto. Por outro lado, em nosso país a legalidade não foi suficiente para impedir a existência de regimes autoritários, como ocorreu em passado recente.

Nesse diapasão, vale transcrever passagem de Eros Roberto Grau ${ }^{277}$ :

A doutrina brasileira tradicional do direito administrativo, isolando-se da realidade, olimpicamente ignora que um conjunto de elementos de índole técnica, aliado a motivações de premência e celeridade na conformação do regime a que se subordina a atividade de intermediação financeira, tornam o procedimento legislativo, com seus prazos e debates prolongados, inadequado à ordenação de matérias essencialmente conjunturais.

(...)

Não é estranho, assim, que essa doutrina - no mundo irreal em que se afaga - não avance um milímetro além da afirmação, por exemplo, de que todas as resoluções do Conselho Monetário Nacional, editadas pelo Banco Central do Brasil, são inconstitucionais!

Na linha do jurista gaúcho, nossa doutrina tradicional peca por não se adaptar aos novos tempos, em que a dinâmica incessante de um mercado global exige respostas rápidas do Estado. Em nosso entender, não obstante o respeito à legalidade seja, sem dúvida, importante para a consecução de valores jurídicos importantes, em si só não basta para tanto. Outros valores, de igual monta, devem ser respeitados, mesmo na dinâmica das agências reguladoras, como a certeza e segurança jurídicas e o devido processo legal.

${ }^{277} \mathrm{GRAU}$, Eros Roberto. O direito posto e o direito pressuposto, cit., p. 173. 


\subsubsection{A superação da legalidade pelos Princípios da Eficiência e da Segurança Jurídica}

Cabe dizer, apenas ad argumentantum tantum, que se considerássemos a legalidade como um princípio, a mesma ainda assim ficaria sujeita a colisão com outro princípio. Usualmente considera-se que colisão de princípios ocorre em face de casos concretos, onde sobreveio determinada situação fática que necessita de uma decisão jurídica para dar solução ao conflito. O mesmo ocorre na solução de lacunas normativas pelo emprego da analogia ou dos princípios. Entretanto, se faz necessário desmistificar algumas colocações tão sedimentadas que configuram, como disse Alfredo Augusto Becker ${ }^{278}$, o "sistema dos fundamentos óbvios".

A concepção habitual leva em conta que lei regula situações “ex ante”, logo, não há lacunas a serem preenchidas, pois, se houver, devem-se à falta de previsão do próprio legislador. Mas se levarmos em conta que o legislador também deve circunscrever sua atuação à Constituição, lei hierarquicamente superior, também ele se depara com situações não expressa ou minuciosamente previstas pela Carta Magna. Nem por isso, pode abster-se de legiferar situações que necessitam de regulação. O mesmo ocorre, talvez de maneira ainda mais drástica, com as agências reguladoras.

Considerando que as agências são erigidas para lidar com segmentos que se notabilizam pela dinamicidade, mormente o mercado de capitais, a necessidade de solucionar as suas vicissitudes exige do órgão poder eventualmente inovar no que se refere a direitos e deveres, principalmente quando há lacunas ou mesmo indeterminações legais, i.e., naqueles casos em que não há regulação por meio de norma legal específica. Do contrário, esvazia-se de sentido a sua própria existência enquanto agência reguladora.

Conforme foi até aqui exposto, a Comissão de Valores Mobiliários opera por intermédio de uma competência normativa "híbrida". Por ora, cumpre esclarecer que - em contextos específicos, quais sejam, naquelas matérias constantes de seu âmbito de atuação, mas que ainda assim não explicitamente tratadas pelas Leis das Sociedades Anônimas e do Mercado de Capitais - tem o poder de inovar no ordenamento jurídico, o que supostamente contraria a legalidade. Esta, todavia, não é mandamento absoluto no sistema e deve ser relativizado quando se trata da atuação das agências reguladoras, incluindo nessa classe, a CVM.

\footnotetext{
${ }^{278}$ BECKER, Alfredo Augusto. Teoria geral do direito tributário. São Paulo: Saraiva, 1963. p. 36.
} 
Essa relativização não é posta pelo aplicador individual, como acontece com os juízes ao decidirem casos concretos, mas pelo próprio sistema. Trata-se de uma superação da regra da legalidade pelos princípios da eficiência e segurança jurídica, tendo por limitadores o devido processo legal e a isonomia.

O fundamento constitucional, portanto, que justifica a regulação por parte das agências, é a preponderância da segurança jurídica sobre a legalidade. A eficiência é apenas um meio de se obter a segurança, que nesses casos, exige que a agência possa inovar na ordem jurídica, prescindindo do poder legislativo. Como esclarece lapidarmente Rachel Sztajn ${ }^{279}$, “as inovações negociais criadas pelos particulares no exercício da autonomia privada aumentam a complexidade dos problemas que requerem rápidas e eficientes respostas do legislador, por isso as agências ou autoridades independentes aparecem como o mecanismo adequado para a intervenção do Estado no setor."

Floriano Azevedo Marques $\mathrm{Neto}^{280}$, ao discorrer sobre a enorme dificuldade em operar dentro dos padrões rígidos e hierarquizados do positivismo jurídico e do cânone da legalidade, centrais ao paradigma até então vigente, assevera:

A relação das agências reguladoras com o Direito se dá em face de uma nova legalidade: a lei define as metas principais e os contornos da atividade do órgão regulador, cometendo-lhe (nestes limites e sob controle do judiciário e do próprio Legislativo) ampla margem de atuação. Atuação esta que segue um novo tipo de discricionariedade, pautado fundamentalmente pelos objetivos definidos na Lei para serem implementados no setor regulador.

Já para Eros Grau ${ }^{281}$, a constante instabilidade dos mercados aliada ao fenômeno da globalização, impõe ao Estado adotar meios jurídicos que o tornem apto a regular imediatamente a conjuntura econômica. Para o autor, esta capacidade normativa de conjuntura, conjugada com a "compreensão de que o processo de desenvolvimento implica uma dinâmica mobilidade social correspondente a adoção de uma nova visão da realidade", faz com que direito necessite, "como todo organismo vivo, estar em constante mutação, impondo-se a superação do descompasso existente entre o ritmo de evolução das

\footnotetext{
${ }^{279}$ SZTAJN, Rachel. op. cit., p. 141.

${ }^{280}$ MARQUES NETO, Floriano Azevedo. Agências reguladoras independentes: fundamentos e seu regime jurídico. Belo Horizonte: Fórum, 2009. p. 108.

281“"Aí, precisamente, o emergir da capacidade normativa de conjuntura, via da qual se pretende conferir resposta à exigência de produção imediata de textos normativos, que as flutuações da conjuntura econômica estão, a todo o tempo, a impor. À potestade normativa através da qual essas normas são geradas, dentro de padrões de dinamismo e flexibilidade adequados à realidade, é que denomino capacidade normativa de conjuntura." (grifos do autor) GRAU, Eros Roberto. O direito posto e o direito pressuposto, cit., p. 172.
} 
realidades sociais e a velocidade de transformação da ordem jurídica."

Se assim não for, áreas extremamente especializadas e dinâmicas como o mercado de capitais não teriam regulação a contento, uma vez que o legislativo não tem conhecimento técnico necessário nem tampouco a celeridade exigida para normatizar esse subsistema econômico. As consequências potencialmente serão piores do que simplesmente cumprir, por amor cego à tradição, com a formalidade legalista.

\subsubsection{3. $O$ artigo $4^{0}$ da Lei $.^{0} 6.385 / 1976$ e as lacunas normativas}

Como vimos, o valores propostos pelo artigo $4^{\circ}$, da Lei do Mercado de Capitais, deverão sempre pautar a atividade normativa da Comissão de Valores Mobiliários, seja no exercício de seu poder normativo regulamentador, seja na regulação por meio de sua competência suplementar.

Ao exercer o que denominamos de competência suplementar, a Comissão regulará matérias de seu âmbito de atuação, que não aquelas expressamente previstas pelas Leis das Sociedades Anônimas e do Mercado de Capitais, sempre norteado pelas metas impostas pelo legislador e, por óbvio, dos ditames constitucionais. Trata-se, como já dito, de importante atuação da CVM, visto que a ela permite dar imediata resposta a um mercado dinâmico, em constante transformação.

Essa atuação, pautada pela capacidade normativa de conjuntura, permite à Comissão de Valores Mobiliários dar conta do dinamismo necessário à regulação do mercado de capitais. Isso significa dizer, em última análise, que proporciona aos agentes respostas técnicas e imediatas, proporcionando ao mercado como um tudo, maior segurança e eficiência.

E não diferente tem sido a atuação da Comissão de Valores Mobiliários. Por vezes, na falta de norma legal ou infralegal específica, a autarquia atua de forma a integrar a lacuna, oferecendo, seja ao caso concreto, por meio de uma regra concreta e individual, seja ao sistema como um todo, por meio de uma regra abstrata e geral, soluções ao mercado. 
É o caso, por exemplo, ocorrido em recente julgamento, datando de outubro de $2011^{282}$, quando foi decidido pelo colegiado da CVM controvérsia envolvendo a inexistência de regra específica que determinasse o prazo para substituição de administrador de clube de investimento.

A Superintendência de Relações com Investidores Institucionais (SIN), em sua manifestação, destacou que a Instrução CVM n. ${ }^{\circ}$ 40/1984, que dispõe sobre a Constituição de funcionamento de Clubes de Investimento, não disciplina o que o administrador deve fazer em hipóteses como a do caso em comento, onde não se consegue implementar uma rescisão da prestação de serviços de administração do clube.

Não obstante, a área técnica ressaltou que a Instrução CVM n. ${ }^{\circ}$ 409/2004, responsável pelo tratamento dado à constituição, administração, funcionamento e divulgação de informações dos fundos de investimento, prevê a ocorrência de situações semelhantes. Diante disso, sugeriu a SIN que, analogamente, fosse aplicado o $\S 1^{\circ}$ do artigo $67^{283}$, da Instrução CVM n. ${ }^{\circ} 409 / 2004$ ao presente caso. Trata-se de dispositivo que estabelece o prazo máximo de 30 dias para que o administrador, após renunciar, permaneça compulsoriamente no exercício de suas funções, de modo que, na inexistência de substitutos para a função, o administrador possa liquidar o fundo.

O Diretor relator Alexsandro Broedel Lopes, em sua manifestação final, apontou que de fato não há regra específica para a solução do caso em comento. Diante disso, o Diretor entendeu ser adequada a sugestão da SIN, de aplicação análoga ao caso, do disposto no artigo 67, parágrafo $1^{\circ}$, da Instrução CVM n. ${ }^{\circ} 409 / 2004$, segundo o qual a substituição dos administradores de fundo de investimento deve ocorrer no prazo máximo de 30 dias, sob pena de liquidação do fundo.

Portanto, a Comissão, ao não localizar quaisquer dispositivos, legais ou infralegais, que dessem tratamento específico à situação analisada, no exercício de sua competência reguladora, utilizou-se de regra abstrata e geral, i.e., o artigo $67, \S 1^{\circ}$, da Instrução CVM n. ${ }^{\circ}$ 409/2004, por analogia, para integrar a lacuna. Ao exercer, neste sentido, sua função

\footnotetext{
${ }^{282}$ Processo Administrativo n ${ }^{\circ}$ RJ 2006-4535.

${ }^{283}$ Art. 67. Nas hipóteses de renúncia ou descredenciamento, ficará o administrador obrigado a convocar imediatamente a assembléia geral para eleger seu substituto, a se realizar no prazo de até 15 (quinze) dias, sendo também facultado aos cotistas que detenham ao menos 5\% (cinco por cento) das cotas emitidas, em qualquer caso, ou à CVM, nos casos de descredenciamento, a convocação da assembléia geral.

$\S 1^{\circ}$ No caso de renúncia, o administrador deverá permanecer no exercício de suas funções até sua efetiva substituição, que deverá ocorrer no prazo máximo de 30 (trinta) dias, sob pena de liquidação do fundo pelo administrador.
} 
julgadora, criou regra concreta e individual inovadora no sistema.

Interessante notar que nesse exemplo, não havia lacuna legal, mas sim de regra abstrata e geral que a própria Comissão de Valores Mobiliários deveria ter inserido no sistema. Como não o fez, faltou regra para solução de um caso concreto, no exercício de sua função julgadora. De forma a integrar o sistema, aplicou regra abstrata e geral que disciplinava caso semelhante - porém não idêntico - valendo-se então de raciocínio analógico.

A dinamicidade que se exige do órgão regulador lhe autoriza empreender com tais fórmulas, de forma a garantir o bom funcionamento do segmento regulado. Outras áreas de atuação da Administração, como a tributária, não tem competência para emprego de analogia (ao menos para aplicação de tributos, como reza o artigo 108, §, do Código Tributário Nacional ${ }^{284}$ ).

${ }^{284}$ Art. 108. (...)

$\S 1^{\circ} \mathrm{O}$ emprego da analogia não poderá resultar na exigência de tributo não previsto em lei. 


\section{CONCLUSÃO}

A regulação é a conexão entre o mundo dos valores e o mundo dos fatos. Com isso, queremos dizer que, ao regular-se condutas, o que se busca é a consecução de determinados e almejados fins, i.e., estimular comportamentos que atendam àquelas máximas que alicerçam o mundo social e o mundo jurídico.

A regulação da conduta, seja em situações de mercado, seja em situações de não mercado, tem como finalidade alcançar duas instâncias de objetivos distintas: objetivos imediatos e objetivos mediatos.

Para o mercado, conforme visto na Teoria Positiva da Regulação, o objetivo imediato da regulação é lidar com as chamadas falhas de mercado, ineficiências que o sistema econômico por si só não é capaz de solucionar, cabendo então ao Estado corrigir tais desvios. Portanto, se o regulador do mercado pretende, de forma imediata, corrigir determinada falha de mercado, é porque, em última análise, o objetivo mediato será o de proporcionar um ambiente justo, equânime de oportunidades para que os agentes possam interagir de forma a eles próprios gerarem bem-estar social.

Mas para que o regulador intervenha neste mercado, de forma a orientar as condutas dos agentes que nele atuam, a fim de alcançar estes objetivos mediatos, é necessária a presença do Direito. Isso porque, conforme fixado no início do trabalho, a regulação se dá por intermédio de normas jurídicas, que obrigam, proíbem e permitem condutas intersubjetivas. Estas normas jurídicas serão elaboradas pelo regulador de forma a orientar condutas, no sentido de alinhá-las com os objetivos mediatos por ele almejados. Assim sendo, teremos nas normas jurídicas o veículo por meio do qual o regulador buscará alcançar tais objetivos.

A competência que confere ao Estado o papel de regulador da ordem econômica está disposta no artigo 174, da Constituição Federal. Cabe, portanto, ao Estado, como interventor na ordem econômica, regular a conduta dos agentes. Esta intervenção estatal, pelas premissas adotadas no presente trabalho, segue a concepção de que regulação não envolve a participação do Estado como agente econômico, mas sim como ponente de normas que coordenam o comportamento dos demais agentes. 
Todavia, não obstante a titularidade do Estado como ente regulador da economia, mostra-se cada vez mais crucial isolar elementos políticos que possam influenciar negativamente tal regulação.

É neste contexto que surgem as agências reguladoras - entes criados sob a forma de Autarquia sob regime especial, com o objetivo de regular áreas específicas. Para salvaguardá-los de possíveis interferências políticas, a estes órgãos foi atribuída maior autonomia, tornando-os órgãos técnicos e especializados.

Para o setor do mercado de capitais foi então criada a Comissão de Valores Mobiliários, por conta de um momento de crise no mercado de capitais brasileiro, no qual se percebeu a necessidade de um órgão especializado, capaz de acompanhar sua dinâmica e regular a conduta de todos que nele atuam.

Esta criação se deu por meio da Lei n. ${ }^{\circ}$ 6.385/1976, que, inicialmente, instituiu a CVM como uma autarquia com menos autonomia para, após a reforma advinda da promulgação da Lei n. ${ }^{\circ}$ 10.411/2002, torná-la uma autarquia sob regime especial, elevando-a ao status de agência reguladora.

Assim, a CVM foi dotada de poder para que, por meio da emissão de normas jurídicas, regulasse o mercado de forma a alcançar os objetivos traçados em lei pelo legislador, notadamente aqueles elencados no artigo $4^{\circ}$, da Lei do Mercado de Capitais.

A Lei n. ${ }^{\circ}$ 6.385/1976, ao criar a referida agência, elencou em seu texto diversas categorias de normas, inclusive aquelas que denominamos de regras de competência. Conforme vimos, tais regras de competência conferem poderes aos órgãos do sistema para produzirem regras. Em outras palavras, estas regras detêm o condão de atribuir à CVM competência para normatizar as hipóteses ali ventiladas, por meio da ponência de regras no sistema.

Tais regras, postas no sistema pela CVM, são as chamadas regras de conduta, aquelas que se dirigem aos agentes do mercado de capitais, no sentido de orientar seu comportamento, obrigando, permitindo ou proibindo determinadas condutas.

Cabe, entretanto, relembrar, que tais regras, todavia, ao serem postas no sistema pela CVM, devem observar certos limites. Limites estes que demarcarão o exercício do poder normativo da Comissão ao, por exemplo, editar uma Instrução, bem com ao proferir uma decisão. 
Mas onde encontramos tais limites?

Primeiramente, podemos localizar restrições de ordem constitucional, i.e., a CVM, ao criar norma não deve, por óbvio, ferir preceitos constitucionais. Assim sendo, uma norma, v.g., com a pretensa finalidade de regular quais agentes poderão atuar no mercado de capitais, não poderá ferir o devido processo legal, sob pena de violar a Constituição Federal.

Ademais, podemos também localizar limites em relação ao âmbito de atuação da Autarquia. Estes limites encontram-se determinados nas próprias Leis n. ${ }^{\circ}$ 6.385/1976 e n. ${ }^{\circ}$ 6.404/1976, diplomas principais que disciplinam a CVM e o mercado de capitais e, portanto, são limites materiais à atuação da CVM.

Ao final, a limitação formal que, em última análise, confere à CVM competência para dar fiel execução às matérias expressamente previstas nos referidos diplomas legais, ou seja, para emitir comandos complementares, a fim de explicitar e operacionalizar os direitos e deveres veiculados nas Leis n. ${ }^{\circ} 6.385 / 1976$ e n. ${ }^{\circ} 6.404 / 1976$.

Deparamo-nos, assim, diante da primeira competência da CVM: a competência normativa regulamentadora. Isto é, a competência para emitir comandos que operacionalizem aquelas matérias expressamente previstas nas Leis das Sociedades Anônimas e do Mercado de Capitais, de forma a dar seu fiel cumprimento.

Ao exercer sua função normativa, valores maiores pautarão a atuação da CVM. Trata-se, neste caso, não apenas daqueles preceitos fixados na Constituição Federal, mas também daqueles específicos da Lei n. ${ }^{\circ}$ 6.385/1976, mais notadamente, aqueles dispostos no artigo $4^{\circ}$. Portanto, a Comissão, ao fazer uso das regras de competência previstas em ambos os diplomas legais, deverá buscar o objetivo de atingir as grandes finalidades relacionadas nos incisos do referido artigo $4^{\circ}$.

São estes os objetivos mediatos que devem ser respeitados e refletidos em cada regulamento de execução que a CVM editar a fim de dar fiel execução às normas postas nas Leis das Sociedades Anônimas e do Mercado de Capitais.

Não obstante a capacidade para emitir comandos com o fulcro de operacionalizar as normas expressamente previstas nas Leis das Sociedades Anônimas e do Mercado de Capitais, pode haver situações em que a Comissão é instigada a manifestar-se de modo a suprir omissões oriundas destes diplomas legais. A função da CVM, nestas situações, 
enquanto órgão regulador do mercado, será justamente a de suprir normativamente situações não previstas pelo legislador ordinário.

É o que chamamos de competência suplementar, ou seja, ao exercer tal competência a Comissão regulará matérias de seu âmbito de atuação, que não aquelas expressamente previstas pelas Leis das Sociedades Anônimas e do Mercado de Capitais, sempre norteado pelas metas impostas pelo legislador e, por óbvio, dos ditames constitucionais.

Trata-se da possibilidade da CVM integrar o sistema jurídico, de forma a preencher lacunas normativas advindas de situações novas no mercado de capitais, cuja complexidade e dinamismo o legislador ordinário não poderia antever. Com isso, se permite que a CVM dê imediata resposta a um mercado dinâmico, em constante transformação.

Os valores propostos pelo artigo $4^{\circ}$, da Lei do Mercado de Capitais, a exemplo do que ocorre quando do exercício do poder normativo regulamentador da Comissão, servirão também como balizas que deverão sempre pautar a atividade normativa da Comissão de Valores Mobiliários na regulação por meio de sua competência suplementar.

Por todo o exposto, concluímos que, dessa forma, a Comissão de Valores Mobiliários é um órgão de competência híbrida, isto é, uma competência que, conforme referido, atribui à $\mathrm{CVM}$, por um lado, poder para formular normas que desdobrem o conteúdo dos princípios e regras contidos nas Leis n. ${ }^{\circ}$ 6.385/1976 e n. ${ }^{\circ}$ 6.404/1976 quando assim por elas previsto, e, por outro lado, poder para formular normas que supram a ausência ou omissão destes diplomas legais, ou seja, competência para editar normas que pormenorizem normas, ou que supram a sua omissão. 


\section{REFERÊNCIAS BIBLIOGRÁFICAS}

ALCHOURRON, Carlos E.; BULYGIN, Eugenio. Introducción a la metodología de las ciencias jurídicas y sociales. Buenos Aires: Astrea, 1993.

ALEXY, Robert. The construction of constitutional rights: law, ethics and human rights. Berkeley Electronic Press, Berkeley, v. 4, n. 1, p. 21, 2010.

ALVARENGA, Maria Isabel de Almeida. Adequação das funções legais da comissão de valores mobiliários à realidade brasileira. Revista de Direito Mercantil, Industrial, Econômico e Financeiro, São Paulo, v. 36, n. 105, p. 144-158, jan./mar. 1997.

AMARAL, Diogo Freitas do. Direito administrativo. Lisboa: Coimbra Ed., 1989. v. 3.

ARAGÃO, Alexandre Santos de. Agências reguladoras e a evolução do direito administrativo econômico. 2. ed. Rio de Janeiro: Forense, 2006.

ARISTÓTELES. Política. Trad. Mário da Gama Kury. 3. ed. Brasília: Ed. da UnB, 1997.

ARROW, Kenneth J. Elección social y valores individuales. Trad. Eusebio Aparicio Aufion. Barcelona: Planeta Agostini, 1994.

ATALIBA, Geraldo. Poder regulamentar no executivo. Revista de Direito Público. São Paulo, v. 14, n. 57-58, 1981.

República e Constituição. 2. ed. São Paulo: Malheiros Ed., 2001.

AUSTIN, John. The province of jurisprudence determined. New York: Prometeus Books, 2000.

BALDWIN, Robert; CAVE, Martin. Understanding regulation: theory, strategy, and practice. New York: Oxford University Press, 1999.

BANNOCK, Graham; BAXTER, R. E.; DAVIS, Evan. The penguin dictionary of economics. 7. ed. Londres: Penguin Books, 2003.

BARRIONUEVO FILHO, Arthur; LUCINDA, Cláudio Ribeiro de. Teoria da regulação. In: BIDERMAN, Ciro; ARVATE, Paulo (Orgs.). Economia do setor público no Brasil. 6. reimp. Rio de Janeiro: Elsevier, 2004.

BARROSO, Luís Roberto. Agências reguladoras: Constituição, transformação do Estado e legitimidade democrática. In: BINENBOJM, Gustavo (Coord.). Agências reguladoras e democracia. Rio de Janeiro: Renovar, 2005. 
BARROSO, Luís Roberto. Apontamentos sobre as agências reguladoras. In: MORAES, Alexandre (Org.). Agências reguladoras. São Paulo: Atlas, 2002.

BECKER, Alfredo Augusto. Teoria geral do direito tributário. São Paulo: Saraiva, 1963.

BENTHAM, Jeremy. The principles of morals and legislation. New York: Prometeu Books, 1988.

BERNSTEIN, Marver H. Regulating business by independent commission. New Jersey: Princeton University Press, 1955.

BINENBOJM, Gustavo. Agências reguladoras, legalidade e direitos fundamentais: limites aos poderes normativo e sancionatório da Anvisa na Regulação de produtos fumígenos. In: ARAGÃO, Alexandre Santos de (Coord.). O poder normativo das agências reguladoras. Rio de Janeiro: Forense, 2006.

BOBBIO, Norberto. Da estrutura à função: novos estudos de teoria do direito. Trad. Daniela Becaccia Versiani. Barueri/SP: Manole, 2007. _. Teoria geral do direito. Trad. Denise Agostinetti. São Paulo: Martins Fontes,

BREYER, S. Typical Justifications for regulation. In: BALDWIN, Robert; SCOTT, Colin; HOOD, Christopher (Orgs.). A Reader on regulation. New York: Oxford University Press, 1998.

BUCHANAN, James; TULLOCK, Buchanan. El cálculo del consenso. Trad. Javier Salinas Sanchez. Buenos Aires: Editorial Planeta Agostini, 1993.

CAETANO, Marcello. Manual de direito administrativo. 10. ed. Coimbra: Almedina, 1997. v. 1.

CALDAS Aulete. 5. ed. Rio de Janeiro: Delta S/A, 1964.

CARVALHO, Cristiano. Ficções jurídicas no direito tributário. São Paulo: Noeses, 2008.

- Teoria da decisão tributária. 2010. Tese (Livre-Docência) - Faculdade de Direito, Universidade de São Paulo, São Paulo, 2010.

CARVALHO, Paulo de Barros. Curso de direito tributário. 14. ed. São Paulo: Saraiva, 2002.

. Curso de direito tributário. 22. ed. São Paulo: Saraiva, 2010.

Direito tributário, linguagem e método. São Paulo: Noeses, 2008. 
CARVALHO, Paulo de Barros. Direito tributário: fundamentos jurídicos da incidência. 4. ed. São Paulo: Saraiva, 2006.

CHOI, Stephen J.; PRITCHARD, A. C. Securities regulation: cases and analysis. New York: Foundation Press, 2005.

CLEAVER, Tony. The basics economics. London: Routledge, 2004.

COMISSÃO DE VALORES MOBILIÁRIOS. Disponível em: <www.cvm.gov.br>. Acesso em: 24 ago. 2011.

COOTER, Robert D.; ULEN, Thomas. Law and economics. New York: Addison Wesley, 2002.

CUÉLLAR, Leila. As agências reguladoras e seu poder normativo. São Paulo: Dialética, 2001.

DI PIETRO, Maria Sylvia Zanella. Direito administrativo. 20. ed. São Paulo: Atlas, 2007.

- Parcerias na administração pública: concessão, permissão, franquia, terceirização e outras formas. 4. ed. São Paulo: Atlas, 2002.

DWORKIN, Ronald. Taking rights seriously. 16. ed. Cambridge: Harvard University Press, 1997.

EIZIRIK, Nelson Laks. Regulação e auto-regulação do mercado de valores mobiliários. Revista de Direito Mercantil, Industrial, Econômico, Financeiro, São Paulo, n. 48, 1982.

; GAAL, Ariadna B.; PARENTE, Flávia; HENRIQUES, Marcus de Freitas. Mercado de capitais: regime jurídico. 2. ed. Rio de Janeiro: Renovar, 2008.

ENGISH, Karl. Introdução ao pensamento jurídico. Trad. João Baptista Machado. 7. ed. Lisboa: Fundação Calouste Gulbenkian, 1996.

FAGUNDES, M. Seabra. O controle dos atos administrativos pelo poder judiciário. 3. ed. atual. Rio de Janeiro: Forense, 1957.

FERRAZ JUNIOR, Tercio Sampaio. Como regular agências reguladoras? Revista Eletrônica de Direito Administrativo Econômico (REDAE). Salvador, Instituto Brasileiro de Direito Público, n. 17, fev./abr. 2009. Disponível em: <<http://www.direitodoestado.com.br/redae.asp>. Acesso em: 18 dez. 2011.

. Competência tributária municipal. Revista de Direito Tributário, São Paulo, ano 14, n. 54, p. 158-163, out./dez. 1990. 
FERRAZ JUNIOR, Tercio Sampaio. Introdução ao estudo do direito: técnica, decisão e dominação. 6. ed. São Paulo: Atlas, 2008.

. Normas gerais e competência concorrente. Revista da Faculdade de Direito da USP, São Paulo, v. 90, p. 250, 1995.

GASPARINI, Diógenes. Direito administrativo. 9. ed. São Paulo: Saraiva, 2004.

GOLDBERG, Victor. Readings in the economics of contract law. Cambridge: Cambridge University Press, 1982.

GOMES, Joaquim Barbosa. Agências reguladoras: a "metamorfose" do Estado e da democracia - uma reflexão de direito constitucional comparado. In: BINENBOJM, Gustavo (Coord.). Agências reguladoras e democracia. Rio de Janeiro: Renovar, 2005.

GRAU, Eros Roberto. O direito posto e o direito pressuposto. São Paulo: Malheiros Ed., 1996.

Ensaio e discurso sobre a interpretação/aplicação do direito. São Paulo: Malheiros Ed., 2002.

GRECO, Marco Aurélio. Medidas provisórias. São Paulo: Ed. Revista dos Tribunais 1991.

GROTTI, Dinorá Adelaide Musetti. As agências reguladoras. Revista Eletrônica de Direito Administrativo Econômico, Salvador, Instituto de Direito Público da Bahia, n. 6, maio/jul. 2006. Disponível em: <http://www.direitodoestado.com.br>. Acesso em: 12 dez. 2011.

GUERREIRO, José Alexandre Tavares. Sobre o poder disciplinar da CVM. Revista de Direito Mercantil, Industrial, Econômico e Financeiro, São Paulo, v. 43, 1981.

HARRISON, Jeffrey L. Law and economics in a nutshell. Sain Paul: Wesley \& Co, 1995.

HART, Herbert L.A. O conceito de direito. Trad. Antonio de Oliveira Sette-Câmara. São Paulo: Martins Fontes, 2009.

JUSTEN FILHO, Marçal. O direito das agências reguladoras independentes. São Paulo: Dialética, 2002.

KAFKA, Franz. O processo. Trad. Modesto Carone. São Paulo: Companhia das Letras, 2005.

KARMEL, Roberta S. Regulation by prosecution: the securities \& exchange commission versus corporate america. New York: Simon and Schuster, 1982. 
KELSEN, Hans. Jurisdição constitucional. 2. ed. Trad. Alexandre Krug. São Paulo: Martins Fontes, 2007.

2003

Teoria pura do direito. Trad. João Paulo Baptista. São Paulo: Martins Fontes,

KRUGMAN, Paul; WELL, Robin. Introdução à economia. Trad. Helga Hoffman. São Paulo: Campus, 2007.

KUHN, Thomas. A estrutura das revoluções científicas. 5. ed. Trad. Beatriz Vianna Boeira e Nelson Boeira. São Paulo: Perspectiva, 1997.

LAMY FILHO, Alfredo; PEDREIRA, José Luiz Bulhões. A Lei das S.A.: pressupostos, elaboração, aplicação. Rio de Janeiro: Renovar, 1992.

LARENZ, Karl. Metodológia de la ciencia del derecho. Trad. para o Espanhol de Marcelino Rodríguez Molinero. Barcelona: Ariel, 1994.

LEÃES, L. G. Paes de Barros. O conceito de 'security' no direito norte-americano e o conceito análogo no direito brasileiro. Revista de Direito Mercantil, Industrial, Econômico e Financeiro, São Paulo, n. 14, 1974.

Mercado de capitais \& insider trading. São Paulo: Ed. Revista dos Tribunais, 1982.

Pareceres. São Paulo: Singular, 2004. v. 1.

LIMA, Ruy Cirne. Princípios de direito administrativo. 5. ed. São Paulo: Ed. Revista dos Tribunais, 1982.

MAGLIANO FILHO, Raymundo. Mercado de capitais: desenvolvimento sustentável. In: ROCCA, Carlos Antonio (Org.). Revolução do mercado de capitais no Brasil: o crescimento recente é sustentável? 2. reimp. Rio de Janeiro: Elsevier, 2008.

MANKIW, Gregory. Princípios de microeconomia. 3. ed. Trad. Allan Vidigal Hastings. São Paulo: Pioneira Thomson Learning, 2005.

MARQUES NETO, Floriano Azevedo. Agências reguladoras independentes: fundamentos e seu regime jurídico. Belo Horizonte: Fórum, 2009.

MATTOS FILHO, Ary Oswaldo; PRADO, Viviane Muller. Tentativas de desenvolvimento do mercado acionário brasileiro desde 1964. In: LIMA, Maria Lúcia de Padua (Coord.). Agenda contemporânea: direito e economia: 30 anos de Brasil. São Paulo: Saraiva: 2012. t. 2. 
MCCRAW, Thomas K. Prophets of regulation. Cambridge: Harvard University Press, 1984.

MEDAUAR, Odete. Direito administrativo moderno. 8. ed. São Paulo: Ed. Revista dos Tribunais, 2004.

MEIRELLES, Hely Lopes. Direito administrativo brasileiro. 23. ed. São Paulo, Malheiros Ed., 1998.

MELLO, Celso Antônio Bandeira de. Curso de direito administrativo. 16. ed. São Paulo: Malheiros Ed., 2003.

MELLO, Oswaldo Aranha Bandeira de. Princípios gerais de direito administrativo. 2. ed. Rio de Janeiro: Forense, 1979. v. 1.

MENDES, Conrado Hübner. Reforma do Estado e agências reguladoras: estabelecendo os parâmetros de discussão. In: SUNDFELD, Carlos Ari (Coord.). Direito administrativo econômico. São Paulo: Malheiros Ed., 2000.

MONTESQUIEU. O espírito das leis. 2. ed. Trad. Fernando Henrique Cardoso; Leôncio Martins Rodrigues. Brasília: Ed. da UnB, 1995.

MORAES, Alexandre de. Agências reguladoras. Revista dos Tribunais, São Paulo, ano 90, v. 791, p. 739-756, set. 2001.

MOREIRA, Egon Bockmann. Processo administrativo: princípios constitucionais e a Lei 9.784/1999. 2. ed. São Paulo: Malheiros Ed., 2003.

MOREIRA, Vital. Auto-regulamentação profissional e administração pública. Coimbra: Almedina, 1997.

MOREIRA NETO, Diogo Figueiredo. Natureza jurídica: competência normativa. Limites de atuação. RDA, $n .215$, p. 71-83, jan./mar. 1999.

MP 00214 MEP MERC VAL MOB CRIAÇÃO DA CVM. Disponível em: $<$ http://www.planalto.gov.br/ccivil_03/Exm/2001/exm-214-mpv-08.pdf>. Acesso em: 16 set. 2011.

NOLL, Roger G. Regulatory policy and the social sciences. Berkeley: University of California Press, 1985.

NORTH, Douglas. Institutions, institutional change and economic performance. Cambridge: Cambridge University Press, 1990. 
OLSON, Mancur. The logic of collective action: public goods and the theory of groups. Cambridge: Harvard University Press, 1965.

PELTZMAN, Sam. The economic theory of regulation after a decade of deregulation. In: BALDWIN, Robert; SCOTT, Colin; HOOD, Christopher (Orgs.). A reader on regulation. New York: Oxford University Press, 1998.

PIÇARRA, Nuno. A separação dos poderes como doutrina e princípio constitucional. Coimbra: Coimbra Ed., 1989.

PINDICK, Robert S., RUBINFELD, Daniel L. Microeconomia. Trad. Eleutério Prado. São Paulo: Prentice Hall, 2002.

PINHEIRO, Armando Castelar; SADDI, Jairo. Direito, economia e mercados. Rio de Janeiro: Elsevier, 2005.

PONTES DE MIRANDA, Francisco Cavalcanti. Comentários à Constituição de 1967 com a Emenda n. 1, de 1969. 2. ed. São Paulo: Ed. Revista dos Tribunais, 1973. t. 3.

POSNER, Richard. Economic analysis of law. New York: Aspen, 2002.

. Teorias da regulação econômica. In: MATTOS, Paulo; PRADO, Mariana Mota; ROCHA, Jean Paul Cabral Veiga da; COUTINHO, Diogo R.; OLIVA, Rafael (Orgs.). Regulação econômica e democracia: o debate norte-americano. São Paulo: Ed. 34, 2004. p. 49-80.

PRESIDÊNCIA DA REPÚBLICA. Mensagem $n^{\circ}$ 1.213, de 31 de outubro de 2001. Disponível em: <http://www.planalto.gov.br/ccivil_03/leis/Mensagem_Veto/2001/Mv1213-01.htm>. Acesso em: 27 nov. 2011.

PROENÇA, José Marcelo Martins. Insider trading: regime jurídico do uso de informações privilegiadas no mercado de capitais. São Paulo: Quartier Latin, 2005.

RAND, Ayn. America's persecuted minority: big business, 1961. Gravação de áudio. Disponível em: $<$ http://www.aynrand.org/site/PageServer?pagename=reg_ar_bigbusiness $>$. Acesso em: 21 dez. 2011.

RIVERO, Jean. Direito administrativo. Coimbra: Almedina, 1981.

ROCHA, Bolívar B. M. O poder normativo de órgãos da administração: o caso da Comissão de Valores Mobiliários. Revista de Direito Mercantil, Industrial, Econômico e Financeiro, São Paulo, v. 64, 1986. 
ROMANO, Roberta. Is regulatory competition a problem or irrelevant for corporate governance? Yale Law School Center for Law, Economics and Public Policy Research Paper, $\quad$ n. $307 . \quad$ Disponível em: $<$ http://papers.ssrn.com/sol3/papers.cfm?abstract_id=693484>. Acesso em: 26 set. 2011.

ROSE-ACKERMAN, Susan. Efficiency, equity and inalienability. In: SCHULENBURG, J.M. Graf von der; SKOGH, G. (Orgs.). Law and economics \& the economics of legal regulation. Dordrecht: Martinus Nijhoff, 1986.

ROSS, Alf. Direito e justiça. Trad. Edson Bini. 2. ed. São Paulo: Edipro, 2007.

SALLES, Marcos Paulo de Almeida. Aspectos da competência do CMN e da CVM no mercado de valores mobiliários. Revista de Direito Mercantil, Industrial, Econômico e Financeiro, São Paulo, v. 36, n. 108, p.101-115, out./dez. 1997.

SATIRO, Francisco. Primeiras notas sobre mercado de capitais. In: SATIRO, Francisco. Mercado de Capitais: aspectos jurídicos. São Paulo: Saraiva. No prelo.

SCHUMPETER, Joseph A. Capitalism, socialism and democracy. New York: Harper and Row, 1998.

SELECTED Speeches of Winston Churchill. Disponível em: $<$ http://www.winstonchurchill.org/learn/speeches/speeches-of-winston-churchill>. Acesso em: 20 nov. 2011.

SILVA, José Afonso da. Curso de direito constitucional positivo. 13. ed. São Paulo: Malheiros Ed., 1997.

SILVEIRA, José Roberto da. Brocados latinos: termos jurídicos. São Paulo: Leud, 2006.

SOUSA, António Francisco de. Conceitos indeterminados no direito administrativo. Coimbra: Almedina, 1994.

STIGLER, George. A teoria da regulação econômica. In: MATTOS, Paulo; PRADO, Mariana Mota; ROCHA, Jean Paul Cabral Veiga da; COUTINHO, Diogo R.; OLIVA, Rafael (Orgs.). Regulação econômica e democracia: o debate norte-americano. São Paulo: Ed. 34, 2004.

STIGLIZ, Joseph. Nobel Prize Lecture. Disponível em: <http://www.nobelprize.org/nobel_prizes/economics/laureates/2001/stiglitz-lecture.pdf>. Acesso em: 10 nov. 2011. 
SUNDFELD, Carlos Ari. A administração pública na era do direito global. In: SUNDFELD, Carlos Ari; VIEIRA, Oscar Vilhena (coords.). Direito global. São Paulo: Max Limonad, 1999.

SZTAJN, Rachel. Regulação e o mercado de valores mobiliários. Revista de Direito Mercantil, Industrial, Econômico e Financeiro, São Paulo, v. 53, n. 135, p. 136-147, jul./set. 2004.

; SALLES, Marcos Paulo de Almeida. Regulação e concorrência no sistema financeiro. Revista de Direito Mercantil, Industrial, Econômico e Financeiro, São Paulo, v. 40, n. 123, p. 41-58, jul./set. 2001.

TÁCITO, Caio. Comissão de Valores Mobiliários. Poder Regulamentar. In: Temas de direito público. Rio de Janeiro: Renovar, 1997. v. 2.

TAVARES, André Ramos. Curso de direito constitucional. 8. ed. São Paulo: Saraiva, 2010.

TRINDADE, Marcelo. Vedações à negociação de valores mobiliários por norma regulamentar: interpretação e legalidade. In: ADAMEK, Marcelo Vieira von (Coord.). Temas de direito societário e empresarial contemporâneos. São Paulo: Malheiros Ed., 2011.

VILANOVA, Lourival. Estruturas lógicas e o sistema de direito positivo. 3. ed. São Paulo, 2005.

WESSELS, Walter J. Economics. 4. ed. New York: Barrons's, 2006.

WRIGHT, Georg von. Norm and action: a logical inquiry. London: Routledge \& Kegan Paul, 1977.

YAZBEK, Otavio. Regulação do mercado financeiro e de capitais. 2 ed. Rio de Janeiro: Elsevier, 2009.

ZINGALES, Luigi. The future of securities regulation. Working Paper. Chicago Booth School of Economics, p. 6, 2009. Disponível em: <http://papers.ssrn.com/sol3/papers.cfm?abstract_id=1319648>. Acesso em: 12 nov. 2011. 